Sabrina Campagna Zignani

\title{
Estudo da estabilidade de catalisadores anódicos em células a combustível
}

Tese apresentada ao Instituto de Química de São Carlos, da Universidade de São Paulo, para a obtenção do título de Doutor em Ciências.

Área de concentração: Físico-Química.

Orientador: Prof. Dr. Ernesto Rafael Gonzalez

São Carlos 
Autorizo a reprodução e divulgação total ou parcial deste trabalho, por qualquer meio convencional ou eletrônico, para fins de estudo e pesquisa, desde que citada a fonte. 
Dedico este trabalho a todos que acreditaram em mim, pela força e apoio para não desanimar. Agradeço também a todas as dificuldades que passei, pois as mesmas me tranformaram em uma pessoa mais forte. 


\section{AGRADECIMENTOS}

Ao Professor Emesto Rafael Gonzalez pela atenção, orientação, pelo conbecimento transmitido e pelo exemplo de profissionalismo e vida.

À minha família, principalmente à minha mãe Salete e meu pai João pelo amor, carinho e atenção, mesmo distantes mas com palavras de apoio e incentivo.

Ao men filho Luigi, pela paciência e por ser men companheiro.

As minhas mais que amigas Evania e Olivia.

Ao meu amigo José pelos ensinamentos.

Ao Valdecir Antonio Paganin pela atenção, compreensão, por todas as sugestões e pelos conselhos.

Aos professores do grupo de eletroquimica pela contribuição para meu crescimento profissional.

Aos companheiros do Laboratório de Eletroquímica pela amizade e sugestões que muito enriqueceram este trabalho.

Ao Instituto de Química de São Carlos - USP pela infra-estrutura de pesquisa e ensino.

Ao Conselho Nacional de Desenvolvimento Cientifico e Tecnológico (CNPq), pela concessão de bolsa.

Ao Conselho Nacional de Pesquisa (CNR) onde fiz estágio de doutorado sanduiche em Messina na Itália, em especial ao Dr. Antonio S. Aricò e Dr. Vincenzo Baglio. 
o tempo passa...

A vida acontece...

A distância separa..

As crianças crescem...

As pessoas não fazem o que deveriam fazer...

Os colegas esquecem os favores...

Mas of verdadeiros amigos estão lá, não importa quanto tempo nem quantos quitometros tenham afastado...

Um amigo nunca está mais distante do que o alcance de uma necessidade, torcendo por nós, intervendino a nosso favor e esperando de bracos abertos abencoando a nossa vida!

Quando iniciamos esta aventura chamada VIDA, não imaginamos as incriveis alegrias e tristezas que experimentaremos pela frente, nem temos noça de quanto precisamos uns dos outros...

Autor desconhecido 


\section{RESUMO}

Eletrocatalisadores de Pt-Sn suportados em carbono de elevada área superficial foram preparados por redução química de precursores metálicos em solução usando como agente redutor o ácido fórmico 0,5 M, 0,1 M e $2 \mathrm{M}$ e caracterizados em termos de estrutura, morfologia e propriedades superficiais para aplicação em células a combustível a etanol direto (DEFC). Os catalisadores foram caracterizados por fluorescência de raios X (XRF), difração de raios X (DRX), espectroscopia de fotoelétrons de raios X (XPS), microscopia eletrônica de transmissão (TEM) e análise termogravimétrica (TGA). Os testes eletroquímicos dos catalisadores foram realizados com o uso de medidas de polarização, voltametria cíclica e linear, testes de estabilidade a potencial constante, e espectroscopia de impedância eletroquímica. A melhor composição atômica superficial, em termos de desempenho eletroquimico foi $\mathrm{Pt}_{3} \mathrm{Sn}_{1} / \mathrm{C}$. Sobrepotenciais ânodicos são necessários de modo a gerar espécies oxidadas na superfície de platina, desta maneira a reação é favorecida. Em termos de produtos de oxidação, o acetaldeído e o ácido acético foram os principais produtos detectados por HPLC, com um baixo teor de $\mathrm{CO}_{2}$. A seletividade para o ácido acético com respeito ao acetaldeído aumentou com o teor de Sn e diminuiu com a menor concentração do agente redutor utilizado na preparação do catalisador. Estudos de estabilidade com base no catalisador $\mathrm{Pt}_{3} \mathrm{Sn}_{1} / \mathrm{C}$ foram realizados e o efeito de diferentes procedimentos de liga/desconexão da célula investigados. Testes de $250 \mathrm{~h}$ a $0.4 \mathrm{~V}$ incluindo tres ciclos de liga/desconexão a 50h, $150 \mathrm{~h}$ e $200 \mathrm{~h}$ são apresentados. Na sequência foram analisados os materiais com testes de estabilidade contínuo de $220 \mathrm{~h} \mathrm{em} \mathrm{0,4} \mathrm{V} \mathrm{com}$ recirculação de etanol. Pode-se dizer que no caso de um procedimento contínuo o sitema é menos afetado devido a menor perda em relação a corrosão do material. Análise morfológica e estrutural pós-testes forneceram informações complementares no que diz respeito ao diagnóstico eletroquímico in-situ e sobre o mecanismo de degradação. $\mathrm{O}$ aspecto mais crítico em relação às perdas irrecuperáveis aparece estar relacionado com a corrosão de Sn. Com base nos resultados obtidos neste trabalho, o protocolo de liga/desconexão foi o que mais afetou o desempenho geral da célula. 


\begin{abstract}
Pt-Sn electrocatalysts supported on carbon having high surface area were prepared by chemical reduction of metal precursors in solution using $0.5 \mathrm{M}, 0.1 \mathrm{M}$ and $2 \mathrm{M}$ formic acid. These electrocatalysts used as anode materials for direct ethanol fuel cells (DEFC), have been physico-chemically characterized in terms of structure, morphology and surface properties. The catalysts were characterized by X-ray fluorescence (XRF), X-ray diffraction (XRD), X-ray photoelectron spectroscopy (XPS), Transmission electron microscopy (TEM) e Thermogravimetric Analysis (TGA). The electrochemical properties of such electrocatalysts were investigated by using polarization measurement, cyclic and linear voltammetry, potentiostatic lifetime tests and electrochemical impedance spectroscopy (EIS). The best composition, in terms of electrochemical performance was the $\mathrm{Pt}_{3} \mathrm{Sn}_{1} / \mathrm{C}$ sample. High anode overpotentials are required in order to generate oxidized species on the platinum surface, which favor the reaction is favored. Essentially, acetaldehyde and acetic acid were detected as the main reaction products, whereas, a low content of $\mathrm{CO}_{2}$ was detected. The selectivity towards acetic acid with respect to acetaldehyde increased with the increase of the Sn content and decreased by decreasing the concentration of the reducing agent used in the catalyst preparation. Stability tests of a DEFC based on a Pt3Sn1/C catalyst was studied and the effect of different cell shut-down procedures investigated. Tests of $250 \mathrm{~h}$ at $0.4 \mathrm{~V}$ cell potential which include three intermediate shut-down/start-up cycles at 50,150 and $200 \mathrm{~h}$ were was analyzed. Stability tests of $220 \mathrm{~h}$ at $0.4 \mathrm{~V}$ with recirculation of ethanol were carried out. In the case of a continuous procedure the system is less affected due to the lower loss compared material. Morphological analysis of structural and post-tests provide additional information regarding the diagnosis and in-situ electrochemical effects on the mechanism of degradation. The most critical aspect in respect of irrecoverable losses appears to be related to the corrosion of Sn. Based on the results obtained in this study, the protocol of start/stop was the one that most affects the overall performance of the cell.
\end{abstract}




\section{LISTA DE ILUSTRAÇÕES}

Figura 1 Esquema de funcionamento de uma célula a combustível do tipo SOFC. 20

Figura 2 Esquema de funcionamento de uma célula a combustível do tipo AFC. 22

Figura 3 Esquema de funcionamento de uma célula a combustível do tipo MCFC. 23

Figura 4 Esquema de funcionamento de uma célula a combustível do tipo PEMFC. 24

Figura 5 Esquema de uma curva de polarização. 26

Figura 6 Conjunto experimental para coleta dos produtos de reação na saída da DEFC 40 antes de análise por HPLC.

Figura 7 Difratogramas de raios X para PtSn/C sintetizados por ácido fórmico $0.5 \mathrm{M} . \quad 41$

Figura 8 Difratogramas de raios X para $\mathrm{PtSn} / \mathrm{C}$ sintetizados por ácido fórmico $1 \mathrm{M} . \quad 42$

Figura 9 Difratogramas de raios X para $\mathrm{PtSn} / \mathrm{C}$ sintetizados por ácido fórmico $2 \mathrm{M} . \quad 42$

Figura 10 Espectros de XPS para $\mathrm{PtSn} / \mathrm{C}$ com diferentes composições atômicas em 45 $0.5 \mathrm{M}, 1 \mathrm{M}$ e $2 \mathrm{M}$ de agente redutor.

Figura 11 Deconvolução de XPS $\mathrm{Pt}^{0}$ picos na região de energia de ligação de 82-66 eV. 46

Figura 12 Deconvolução de XPS $S_{n}{ }^{4+}$ picos na região de energia de ligação de 500-480 48 $\mathrm{eV}$.

Figura 13 Perfil de TG-DSC dos catalisadores PtSn /C.

Figura 14 Micrografias obtidas por microscopia eletrônica de transmissão e histogramas da frequência do tamanho médio de partículas dos eletrocatalisadores de Pt$\mathrm{Sn} / \mathrm{C}$ preparados com $0.5 \mathrm{M}$ de $\mathrm{HCOOH}$.

Figura 15 Micrografias obtidas por microscopia eletrônica de transmissão e histogramas da frequência do tamanho de partículas dos eletrocatalisadores de Pt-Sn/C preparados com $1 \mathrm{M}$ de $\mathrm{HCOOH}$.

Figura 16 Micrografias obtidas por microscopia eletrônica de transmissão e histogramas da frequência do tamanho de partículas dos eletrocatalisadores de Pt-Sn/C preparados com $2 \mathrm{M}$ de $\mathrm{HCOOH}$.

Figura 17 Curvas de polarização dos catalisadores de $\mathrm{PtSn} / \mathrm{C}$ preparados com $0.5 \mathrm{M}$ de $\mathrm{HCOOH}$, catalisadores com $1 \mathrm{mg}$ de $\mathrm{Pt} \mathrm{cm} \mathrm{cm}^{-2}$ no cátodo e $2 \mathrm{mg}$ de $\mathrm{Pt} \mathrm{cm}^{-2}$ no ânodo. 
Figura 18 Curvas de polarização dos catalisadores de $\mathrm{PtSn} / \mathrm{C}$ preparados com $1 \mathrm{M}$ de $\mathrm{HCOOH}$, catalisadores com $1 \mathrm{mg}$ de $\mathrm{Pt} \mathrm{cm}{ }^{-2}$ no cátodo e $2 \mathrm{mg} \mathrm{de} \mathrm{Pt} \mathrm{cm}^{-2}$ no ânodo.

Figura 19 Curvas de polarização dos catalisadores de $\mathrm{PtSn} / \mathrm{C}$ preparados com $2 \mathrm{M}$ de $\mathrm{HCOOH}$, catalisadores com $1 \mathrm{mg}$ de $\mathrm{Pt} \mathrm{cm}^{-2}$ no cátodo e $2 \mathrm{mg}$ de $\mathrm{Pt} \mathrm{cm}^{-2}$ no ânodo.

Figura 20 Voltametria de varredura linear dos materiais Pt-Sn preparados com $0.5 \mathrm{M}$ de $\mathrm{HCOOH}$, eletrodos com $1 \mathrm{mg}$ de $\mathrm{Pt} \mathrm{cm}{ }^{-2}$ no cátodo e $2 \mathrm{mg}$ de $\mathrm{Pt} \mathrm{cm}^{-2}$ no ânodo, célula alimentada com etanol $1 \mathrm{~mol} \mathrm{~L}^{-1}$ a $2 \mathrm{ml} \mathrm{min}^{-1}$ no ânodo e hidrogênio no cátodo. $\mathrm{V}=10 \mathrm{mV} / \mathrm{s}$ temperatura da célula = a) $\mathrm{T} 70{ }^{\circ} \mathrm{C} \mathrm{e}$ b) $\mathrm{T} 90^{\circ} \mathrm{C}$.

Figura 21 Voltametria de varredura linear dos materiais $\mathrm{Pt}-\mathrm{Sn} / \mathrm{C}$ preparados com $1 \mathrm{M}$ de 59 $\mathrm{HCOOH}$, eletrodos com $1 \mathrm{mg}$ de $\mathrm{Pt} \mathrm{cm}^{-2}$ no cátodo e $2 \mathrm{mg}$ de $\mathrm{Pt} \mathrm{cm}^{-2}$ no ânodo, célula alimentada com etanol $1 \mathrm{~mol} \mathrm{~L}^{-1}$ a $2 \mathrm{ml} \min ^{-1}$ no ânodo e hidrogênio no cátodo. $\mathrm{V}=10 \mathrm{mV} / \mathrm{s}$ temperatura da célula $=$ a) $\mathrm{T} 70{ }^{\circ} \mathrm{C}$ e b) $\mathrm{T} 90^{\circ} \mathrm{C}$.

Figura 22 Voltametria de varredura linear dos materiais Pt-Sn/C preparados com 2M de $\mathrm{HCOOH}$, eletrodos com $1 \mathrm{mg}$ de $\mathrm{Pt} \mathrm{cm}^{-2}$ no cátodo e $2 \mathrm{mg}$ de $\mathrm{Pt} \mathrm{cm}^{-2}$ no ânodo, célula alimentada com etanol $1 \mathrm{~mol} \mathrm{~L}^{-1}$ a $2 \mathrm{ml} \mathrm{min}^{-1}$ no ânodo e hidrogênio no cátodo. $\mathrm{V}=10 \mathrm{mV} / \mathrm{s}$ temperatura da célula: a) $\mathrm{T} 70{ }^{\circ} \mathrm{C}$ e b) $\mathrm{T}$ $90^{\circ} \mathrm{C}$.

Figura 23 Cronoamperometrias a $0,4 \mathrm{~V}$ dos materiais $\mathrm{Pt}-\mathrm{Sn} / \mathrm{C}$ preparados com $0,5 \mathrm{M}$ de $\mathrm{HCOOH}$, eletrodos com $1 \mathrm{mg}$ de $\mathrm{Pt} \mathrm{cm}^{-2}$ no cátodo e $2 \mathrm{mg}$ de $\mathrm{Pt} \mathrm{cm}^{-2}$ no

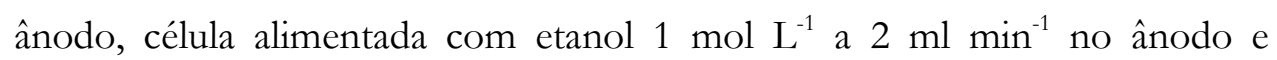
oxigênio no cátodo, temperatura da célula: a) $\mathrm{T} 70{ }^{\circ} \mathrm{C}$ e b) $\mathrm{T} 90^{\circ} \mathrm{C}$.

Figura 24 Cronoamperometrias a $0,4 \mathrm{~V}$ dos materiais $\mathrm{Pt}-\mathrm{Sn} / \mathrm{C}$ preparados com $1 \mathrm{M}$ de $\mathrm{HCOOH}$, eletrodos com $1 \mathrm{mg}$ de $\mathrm{Pt} \mathrm{cm}^{-2}$ no cátodo e $2 \mathrm{mg}$ de $\mathrm{Pt} \mathrm{cm}^{-2}$ no ânodo, célula alimentada com etanol $1 \mathrm{~mol} \mathrm{~L}^{-1}$ a $2 \mathrm{ml} \mathrm{min}{ }^{-1}$ no ânodo e oxigênio no cátodo, temperatura da célula: a) $\mathrm{T} 70{ }^{\circ} \mathrm{C}$ e b) $\mathrm{T} 90{ }^{\circ} \mathrm{C}$.

Figura 25 Cronoamperometrias a $400 \mathrm{mV}$ dos materiais $\mathrm{Pt}-\mathrm{Sn} / \mathrm{C}$ preparados com $2 \mathrm{M}$ de $\mathrm{HCOOH}$, eletrodos com $1 \mathrm{mg}$ de $\mathrm{Pt} \mathrm{cm}^{-2}$ no cátodo e $2 \mathrm{mg}$ de $\mathrm{Pt} \mathrm{cm}^{-2}$ no ânodo, célula alimentada com etanol $1 \mathrm{~mol} \mathrm{~L}^{-1}$ a $2 \mathrm{ml} \mathrm{min}^{-1}$ no ânodo e oxigênio no cátodo, temperatura da célula: a) $\mathrm{T} 70{ }^{\circ} \mathrm{C}$ e b) $\mathrm{T} 90{ }^{\circ} \mathrm{C}$.

Figura 26 Produtos de reação formados durante a operação: a) $70^{\circ} \mathrm{C}$ e b) $90^{\circ} \mathrm{C}$. 
Figura 27 Voltamogramas cíclicos dos eletrocatalisadores $\mathrm{Pt} / \mathrm{C}$ e $\mathrm{Pt}_{3} \mathrm{Sn} / \mathrm{C}$ em solução de $0,5 \mathrm{~mol} \mathrm{~L}^{-1}$ de $\mathrm{H}_{2} \mathrm{SO}_{4}$

Figura 28 Curvas amperométricas em $1 \mathrm{~mol} \mathrm{~L}^{-1}$ de etanol em solução de $0,5 \mathrm{~mol} \mathrm{~L}^{-1}$ de $\mathrm{H}_{2} \mathrm{SO}_{4}$ para os eletrocalisadores de $\mathrm{Pt} / \mathrm{C}$ e $\mathrm{Pt}_{3} \mathrm{Sn} / \mathrm{C}$.

Figura 29 (-) Stripping de $\mathrm{CO}$ em meio de $\mathrm{H}_{2} \mathrm{SO}_{4} 1 \mathrm{M}$ para os eletrocalisadores de Pt/C. ( $($ ) Voltamograma subsequente ao stripping de CO.

Figura 30 (-)Stripping de $\mathrm{CO}$ em meio de $\mathrm{H}_{2} \mathrm{SO}_{4} 1 \mathrm{M}$ para os eletrocalisadores de $\mathrm{Pt}_{3} \mathrm{Sn} / \mathrm{C}$. (-) Voltamograma subsequente ao stripping de CO.

Figura 31 Teste de estabilidade de $250 \mathrm{~h}$ em 0,4 V, que inclui três ciclos ligadodesconexão intermediários a 50,155 e 200 h do catalisador de PtSn/C.

Figura 32 Esquema representativo da variação dos potenciais do ânodo e do cátodo durante o período de desconexão da célula.

Figura 33 Curvas de polarização a intervalos diferentes do ensaio de estabilidade.

Figura 34 Espectros de impedância a intervalos diferentes do ensaio de estabilidade.

Figura 35 Difratogramas dos catalisadores utilisados antes e após o teste de estabilidade: (a) no ânodo, (b) no cátodo

Figura 36 Micrografias e histogramas do ânodo após testes de estabilidade.

Figura 37 Micrografias e histogramas do cátodo após testes de estabilidade.

Figura 38 Teste de estabilidade realizado por 220 h em $0,4 \mathrm{~V}$ com recirculação de etanol.

Figura 39 Espectros de impedância antes e após o teste de estabilidade de 220h.

Figura 40 Curvas de polarização a intervalos diferentes do ensaio de estabilidade de $220 \mathrm{~h}$.

Figura41 Voltametrias cíclias em célula unitária a intervalos diferentes do ensaio de estabilidade de $220 \mathrm{~h}$. 


\section{LISTA DE TABELAS}

Tabela 1 Propriedades estruturais dos catalisadores de PtSn/C.

Tabela 2 Composição atômica superficial derivada dos resultados de XPS.

Tabela $3 \mathrm{BE}$ e as intensidades relativas de diferentes espécies provenientes dos espectros de XPS nos vários catalisadores de $\mathrm{Pt}-\mathrm{Sn} / \mathrm{C}$.

Tabela 4 Tamanho do cristalito e parâmetro de rede dos catalisadores usados no ensaio de estabilidade. 


\section{LISTA DE ABREVIATURAS E SIGLAS}

PEMFCs- Célula a Combustível de Membrana Trocadora de Prótons

DEFC - Célula a Combustível de etanol direto

MAF - Método de redução química de metais utilizando o Ácido Fórmico.

MEA - Conjunto membrana eletrodo

BET - Área superficial obtida por absorção de nitrogênio

Pt-Sn - Catalisadores bimetálicos contendo platina e estanho

$\mathrm{Pt}_{9} \mathrm{Sn}_{1}$ - Catalisador bimetálico contendo 9 átomos de Pt para 1 átomo de Sn.

$\mathrm{Pt}_{3} \mathrm{Sn}_{1}$ - Catalisador bimetálico contendo 3 átomos de Pt para 1 átomo de Sn.

$\mathrm{Pt}_{1} \mathrm{Sn}_{1}$ ou PtSn - Catalisador bimetálico contendo 1 átomos de Pt para 1 átomo de Sn.

PTFE - Politetrafluoretileno

EDX - Energia dispersiva de raios-X

DRX - Difração de raios-X

XRF - Fluorescência de raios X

XPS - Espectroscopia Foto Eletrônica de Raios-X

TGA- Análise termogravimétrica

HRTEM - Microscopia eletrônica de transmissão de alta resolução.

EIS - Espectroscopia de Impedância Eletroquímica

VC-Voltametria cíclica

EDR - Eletrodo de disco rotatório

EDG- Eletrodo de difusão de gás 


\section{SUMÁRIO}



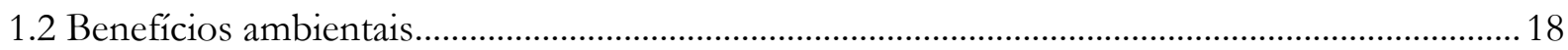

1.2.1 Dependência de produtos do petróleo para produzir energia:................................................18

1.2.2 Maior eficiência na geração da energia e no consumo da fonte de energia .............................. 19

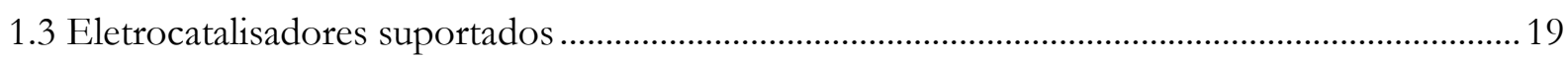

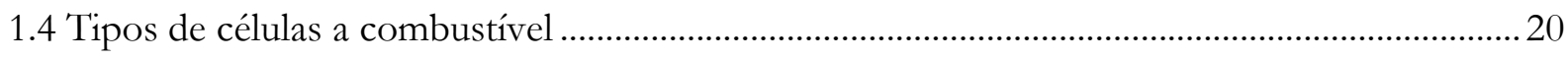

1.4.1 Célula a combustível de óxido sólido (SOFC - Solid Oxide Fuel Cell) .........................................20

1.4.2 Célula a combustível alcalina ( AFC - Alkaline Fuel Cells).............................................................21

1.4.3 - Células de carbonatos fundidos (MCFC - Molten Carbonate Fuel Cell) .....................................22

1.4.4 Células a Combustível de Membrana Trocadora de Prótons (PEMFC)...................................23

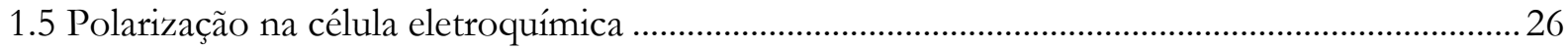

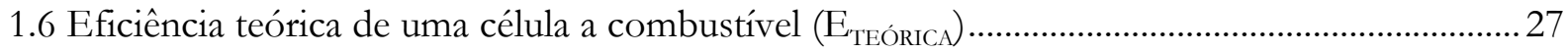

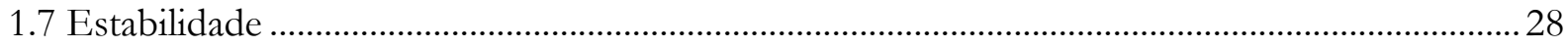





1.10 Mecanismos da reação de oxidação eletroquímica de etanol em Pt pura ..................................32

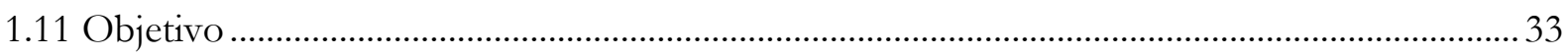



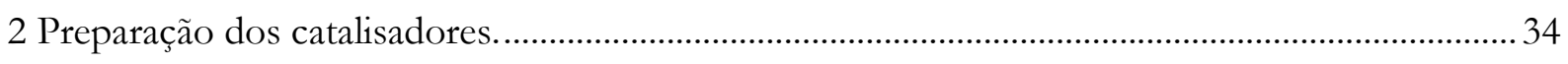

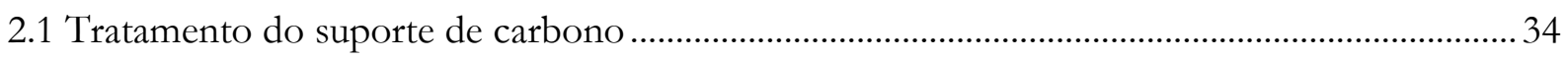

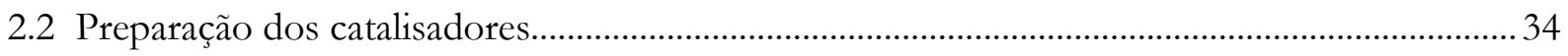

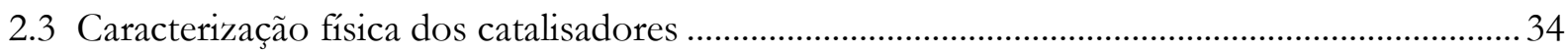



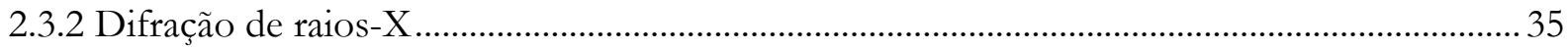

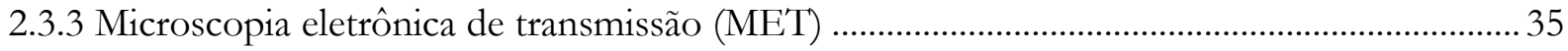

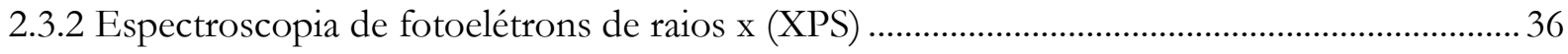

2.4 Preparação dos eletrodos para a célula eletroquímica........................................................................ 36



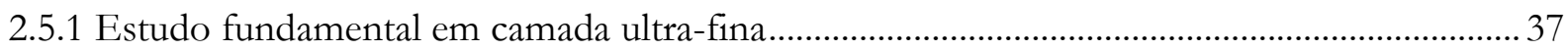

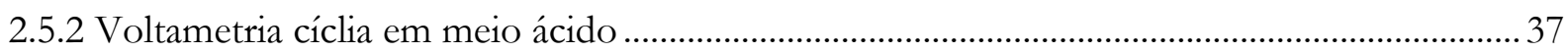

2.5.3 Oxidação de CO adssorvido (Stripping de CO) ............................................................................. 38






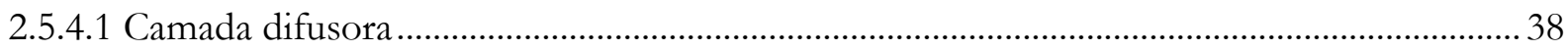

2.5.4.2 Preparação do conjunto membrana-eletrodos (MEA) ........................................................... 39

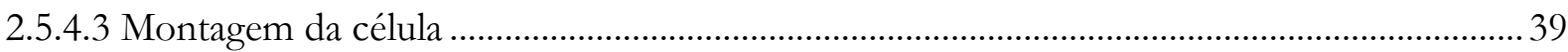

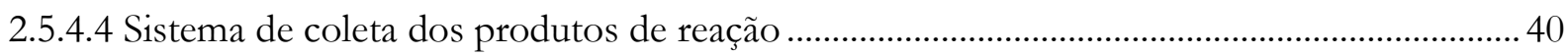

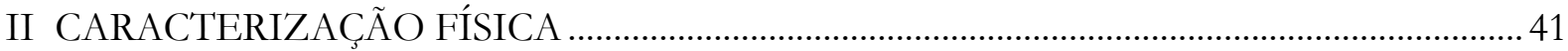

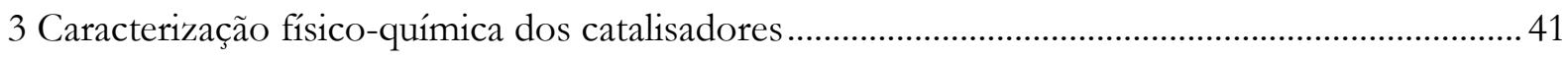

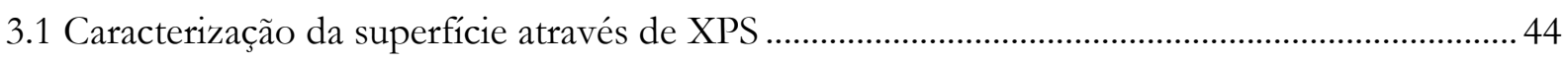

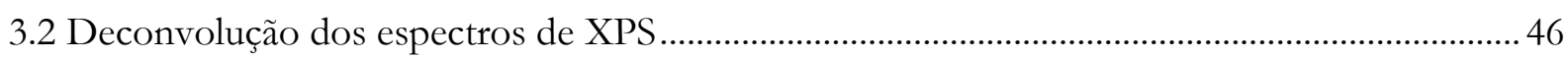

3.3 Análise termogravimétrica (TGA) em atmosfera de ar................................................................. 49

3.4 Microscopia eletrônica de transmissão de baixa resolução (MET) …………………………….... 50

IV PARTE I - ELETROOXIDAÇÃO DE ETANOL ……………………………………............ 54

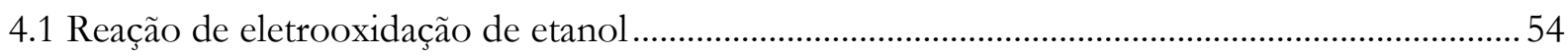

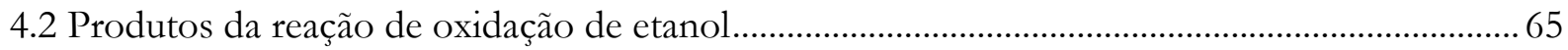

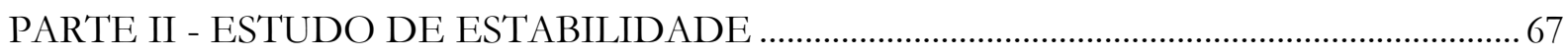

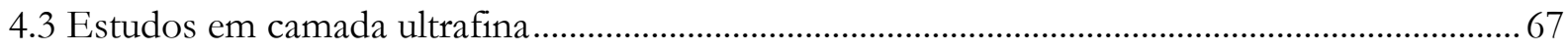

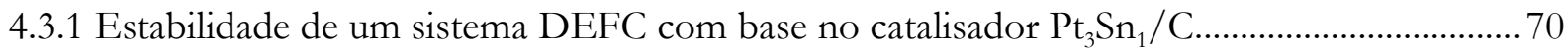

4.3.2 Estratégia de estudo dos testes de estabilidade ............................................................................. 71

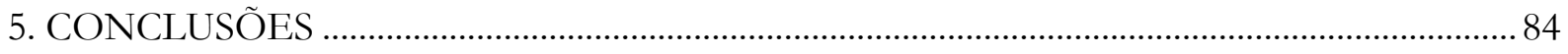

6. TRABALHOS PUBLICADOS NO PERÍODO DO DOUTORADO........................................ 85

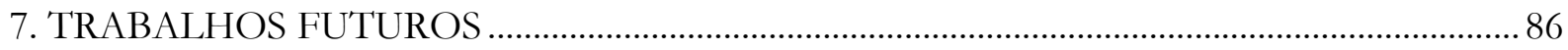

8. ANEXOS

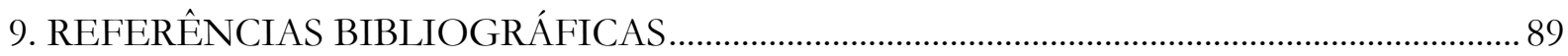




\section{$\underline{\text { Capítulo I }}$}

\section{INTRODUÇÃO}

Fontes de energia alternativa tornam-se necessárias e urgentes e várias razões justificam as pesquisas nesta área. A nível mundial o principal insumo para geração de energia é o petróleo contribuindo com 38\% da energia gerada, ficando em segundo lugar o carvão com $24,7 \%$ em terceiro o gás natural com $23,7 \%$, seguidos da energia nuclear com $6,6 \%$ e o sistema hidrelétrico com 6,5\%. (1) Muitas pesquisas apontam que o pico da produção de petróleo está relativamente próximo. Após esse pico, a produção deve tornar-se cada vez menor, tornando esse combustível cada vez mais caro, o que pode ocasionar crises econômicas terríveis na maior parte dos países, além disso deve-se levar em conta na agenda política a questão da segurança energética. (2) Um país não pode tornar-se dependente de uma única ou poucas fontes de energia. A produção de petróleo atualmente está nas mãos de cerca de 20 nações, o que representa um grande risco à segurança energética. Quanto mais variada for a matriz energética de uma nação, mais segurança poderá proporcionar.

A maior parte da matriz energética brasileira (mais de 60\%) provém de combustíveis fósseis, sendo o petróleo a principal fonte de energia. O uso dos derivados do petróleo responde por aproximadamente $42 \%$ de nossa matriz, e o setor veicular é responsável por aproximadamente $50 \%$ deste total.

A energia elétrica é um dos insumos básicos para o desenvolvimento econômico e social. No entanto, trinta e cinco por cento da população mundial não tem qualquer acesso à ela. As fontes de energia renováveis apresentam-se como a solução para atender essa carência e também ao rápido crescimento do consumo mundial. Mesmo em países com matriz energética baseada na fonte renovável da energia hídrica, caso do Brasil, pode ocorrer carência no abastecimento devido a problemas climáticos. Por esta razão, as fontes de energia a serem adotadas terão que ser compatíveis com as necessidades de países diferentes e ao mesmo tempo realçar a segurança de cada opção alternativa. Estudos revelam que um tipo de energia confiável, renovável e não poluente se faz necessário mediante as preocupações que envolvem a sustentabilidade ambiental. Dentro dessa proposta e de buscas voltadas para uma geração de energia mais eficiente destaca-se

a célula combustível, (3) que dentre as diferentes tecnologias não envolve combustão. É a combinação de hidrogênio e oxigênio que resulta num dispositivo eletroquímico, produzindo eletricidade, calor e água. Uma tecnologia que está em pleno desenvolvimento. (1) 


\section{$\underline{\text { Capítulo I }}$}

As aplicações mais importantes para as células a combustível são as centrais de produção de electricidade estacionárias e de distribuição, veículos elétricos motorizados e equipamentos elétricos portáteis. Pesquisas de desenvolvimento de células a combustível (4) estão sendo realizadas em todo o mundo por empresas de energia, montadoras de automóveis, fabricantes de equipamentos eletrônicos, universidades e centros de pesquisa especializados em energia alternativa, com o objetivo de diminuir custos e dimensões, aumentar a eficiência dos equipamentos e diminuir a dependência de combustíveis fósseis, como o petróleo que automaticamente geram problemas econômicos e sociais. (5) Uma das características das células a combustível é o fato do tamanho exercer praticamente nenhuma influência sobre a eficiência. Isto significa que podem ser desenvolvidas centrais de produção elétrica pequenas, com elevada eficiência, evitando os custos excessivos envolvidos no desenvolvimento de centrais elétricas convencionais.

\subsection{Breve histórico}

Apesar da alta tecnologia empregada para o seu funcionamento, as células a combustível são conhecidas pela ciência há mais de 150 anos. Embora, as células a combustível tenham sido consideradas uma grande curiosidade do século XIX, elas foram alvos de intensas pesquisas principalmente durante a Segunda Guerra Mundial. A primeira célula a combustível foi construída em 1801 por Humphrey Davy, que realizou estudos em eletroquímica usando carbono e ácido nítrico. Mas o advogado e cientista inglês, William Grove (1811-1896), que foi considerado o precursor das células a combustível. (6) A "Célula de Grove”, como era chamada, usava um eletrodo de platina imerso em ácido nítrico e um eletrodo de zinco imerso em sulfato de zinco para gerar uma corrente de 12 amperes e uma tensão de 1,8 volts. Grove descobriu que colocando dois eletrodos de platina com cada lado de cada eletrodo imerso num tubo contendo ácido sulfúrico diluído, e os outros dois lados separadamente conectados em tubos fechados com oxigênio e hidrogênio, uma corrente contínua circularia entre os eletrodos. Os tubos isolados e fechados produziam água e também gases, e ele notou que o nível de água aumentou em ambos os tubos onde a corrente elétrica passou.

Em seguida, Grove construiu uma fonte de energia usando vinte e seis células em série e foi o primeiro a notar e explicitar a dificuldade de produzir altas densidades de corrente elétrica em uma pilha a combustível (várias células a combustível conectadas em série), que utiliza gases 


\section{$\underline{\text { Capítulo I }}$}

como reagentes. O problema que enfrentou na época ainda está sendo estudado atualmente por pesquisadores da área. Em 1800, os cientistas britânicos William Nicholson e Anthony Carlisle descreveram o processo de usar eletricidade para decompor a água em hidrogênio e oxigênio. Mas combinar os gases para produzir eletricidade e água foi a grande descoberta de William Grove. Logo depois ele chamou o dispositivo desta experiência como a "bateria a gás" - a primeira célula a combustível.

O químico Ludwig Mond dedicou a maior parte da sua carreira desenvolvendo tecnologias para a indústria química tal como o refinamento de níquel. Em 1889, Mond e seu assistente Carl Langer, descreveram a sua experiência com a célula a combustível a hidrogênio e oxigênio. A experiência produziu uma corrente elétrica de 6 amperes - densidade de corrente de 2,8 a $3,5 \mathrm{~mA} / \mathrm{cm}^{2}$ - numa pequena área de eletrodo de $700 \mathrm{~cm}^{2}$ produzindo uma tensão de 0,73 volts. A célula a combustível de Mond e Langer usava $0,35 \mathrm{~g}$ de finos eletrodos de platina porosos e um eletrólito de ácido sulfúrico. Eles observaram dificuldades utilizando eletrólitos líquidos, pois somente obtinham sucesso utilizando eletrólitos em forma sólida.

Já o cientista e fundador do campo da físico-química, Friedrich Wilhelm Ostwald, contribuiu com muitas das teorias sobre as células a combustível. Em 1893, ele determinou experimentalmente as funções dos vários componentes de uma célula a combustível: eletrodos, eletrólito, agentes de oxidação e redução, ânions e cátions. William Grove especulava que as reações que ocorriam na sua bateria de gás ocorriam nos pontos de contato entre eletrodos, gás e eletrólito, mas não sabia explicar além disso. Já Ostwald, que desenvolveu a relação entre as propriedades físicas e reações químicas, resolveu a incógnita do funcionamento da célula de gás de William Grove. Sua pesquisa sobre o funcionamento químico das células foi a base de trabalho para as pesquisas sobre célula a combustível nos anos seguintes por outros pesquisadores.

$\mathrm{Na}$ primeira metade do século XX, o cientista suíço Emil Baur, juntamente com seus estudantes, conduziu uma grande quantidade de pesquisas com vários tipos de tecnologias de células a combustível. Parte do trabalho de Emil Baur incluiu dispositivos de alta temperatura (utilizando prata fundida como eletrólito) e um eletrólito sólido de argila e óxidos metálicos.

No final do séc XX, Francis Thomas Bacon começou pesquisando célula a combustível de eletrólito alcalino (AFC- Alkaline Fuel Cell) de alta pressão, que parecia oferecer resultados viáveis. Em 1939, ele construiu uma célula que usava eletrodos de níquel e operava numa pressão de até $220 \mathrm{~atm}$ numa temperatura de $100{ }^{\circ} \mathrm{C}$. Durante a Segunda Guerra Mundial, Bacon trabalhou no desenvolvimento de células que poderiam ser usadas nos submarinos da marinha inglesa, e em 1958 demonstrou o funcionamento de uma célula a combustível alcalina usando um dispositivo com eletrodo de 10 polegadas $(25,4 \mathrm{~cm})$ de diâmetro. 


\section{$\underline{\text { Capítulo I }}$}

Embora fossem extremamente caras, as células a combustível de Francis Bacon provaram ser suficientemente confiáveis para atrair a atenção da Pratt \& Whitney. Esta empresa se uniu com a Energy Conversion, que tinha Francis Bacon como consultor e licenciou o trabalho dele para ser utilizado no desenvolvimento de um sistema de geração de energia para as missões espaciais Gemini e Apollo da Nasa. Este sistema era constituído por três unidades de pilhas a combustível alcalinas e operavam a pressões de 3,5 atm. Na seqüência do desenvolvimento tecnológico, a temperatura das células foi aumentada para $200{ }^{\circ} \mathrm{C}$, e produziam potência de 1,4 kW cada. A tensão desenvolvida variava entre 27 e 31 volts, com uma vida útil limitada em 400 horas de operação, devido principalmente à corrosão do cátodo (eletrodo). Após as missões Apollo, a construção de novas células a combustível alcalinas operando com altas pressões, foi paralisada e tornou-se claro, levando em conta esse tipo de células, que sua comercialização tinha como principais obstáculos o alto custo e a pequena vida útil.

Atualmente, as células a combustível apresentam uma evolução em durabilidade, diminuição dos custos e são uma das principais soluções energéticas ambientalmente amigáveis. É só uma questão de tempo para que as células a combustível estejam fazendo parte da vida das pessoas como ocorreu com os computadores.

\subsection{Benefícios ambientais}

\subsubsection{Dependência de produtos do petróleo para produzir energia:}

Petróleo, gás natural e carvão são combustíveis fósseis que têm certas desvantagens. O petróleo é uma fonte limitada, o gás natural é difícil de transportar, e o carvão é extremamente agressivo ao meio ambiente. As células a combustível poderão satisfazer nossa demanda por energia ao mesmo tempo em que as reservas de combustíveis fósseis diminuirão. Para isso, devem-se utilizar fontes renováveis de energia, como a cana-de-açúcar e outras fontes de biomassa, pois durante o seu crescimento, ocorre o sequestro de carbono da atmosfera.

A maior parte das células a combustível emitem água e calor como seus subprodutos. Imaginem dentro de alguns anos que a maior parte da frota de automóveis emita somente estes componentes ao invés de monóxido de carbono, dióxido de carbono e outros gases nocivos, além da fumaça. Embora algumas células a combustível emitam dióxido de carbono, a emissão é em pequenas quantidades. 


\section{$\underline{\text { Capítulo I }}$}

\subsubsection{Maior eficiência na geração da energia e no consumo da fonte de energia}

Atualmente, os motores a combustão interna mais eficientes atingem eficiência de $25 \% \mathrm{a}$ 30\%. Em média, a eficiência varia de 13 a 20\%. As plantas mais eficientes de geração de energia têm eficiência de 33 a 35\%. As células a combustível mais usuais e maduras no momento, as de ácido fosfórico (PAFC) e as que utilizam metanol (DMFC), têm eficiência de 40\%. Entretanto, quando é utilizado num sistema de cogeração (em que se aproveita o calor rejeitado para gerar mais energia), as células de ácido fosfórico podem obter eficiência de 85\%. Outras tecnologias de células a combustível têm suas eficiências variando desde $40 \%$ até $85 \%$. De um modo geral, todas as células a combustível têm eficiência maior que os motores a combustão e plantas de geração.

\subsection{Eletrocatalisadores suportados}

No contexto de pesquisa e desenvolvimento de células a combustível de baixa temperatura de operação, a atividade catalítica de materiais suportados como nanopartículas de platina (2-5 nm) suportadas em carbono e sistemas binários Pt-M/C, onde M geralmente é um metal de transição como $\mathrm{Sn}, \mathrm{Ni}, \mathrm{Co}, \mathrm{Ru}$, etc., frente as reações anódicas e catódicas tem sido extensivamente estudada, exemplos são a eletro-oxidação de hidrogênio, (7) monóxido de carbono, (8) metanol (9) e etanol, (10) e reação de redução de oxigênio. (11) Na maioria dos casos, as nanopartículas estão ancoradas em um substrato poroso de elevada área superficial (> $250 \mathrm{~m}^{2} \mathrm{~g}^{-1}$ ), o carbono Vulcan. (12) Esse por sua vez cumpre os requisitos esperados para um bom suporte dentro da eletrocatálise, ou seja, ser estável quimicamente no eletrólito e possuir elevada condutividade elétrica.

Entretanto, em alguns casos, a formação de alguns grupos funcionais na superfície do carbono pode aumentar sua resistência elétrica, limitando o desempenho em altas densidades de corrente. (13) Estudos mostram que a oxidação do carbono Vulcan estaria diretamente relacionada à estabilidade das nanopartículas de Pt suportadas e, portanto, a perdas de desempenho. (14) 


\section{$\underline{\text { Capítulo I }}$}

\subsection{Tipos de células a combustível}

\subsubsection{Célula a combustível de óxido sólido (SOFC - Solid Oxide Fuel Cell)}

A célula a combustível do tipo SOFC é muito vantajosa devido à possibilidade da utilização de larga variedade de combustíveis. A maioria das células a combustíveis utiliza o hidrogênio como combustível, já as SOFCs podem funcionar com hidrogênio, butano, metanol e outros derivados do petróleo. Para cada tipo de combustível, há um ânodo, cátodo e eletrólito distinto. A caracteristica desta tecnologia é a utilização de um eletrólito cerâmico não-poroso condutor iônico. O estado da arte para este esse material é a utilização de zircônia estabilizada com ítria. Estas células operam em alta temperatura $\left(800-1000{ }^{\circ} \mathrm{C}\right)$, o que favorece bastante a cinética das reações e possibilita a reforma interna do combustível.

Seguem as equações químicas para a reação:

Reação ânodo: $\mathrm{CH}_{3} \mathrm{OH}_{(\mathbb{1})}+\mathrm{H}_{2} \mathrm{O}_{(\mathbb{l})} \rightarrow \mathrm{CO}_{2(\mathrm{~g})}+6 \mathrm{H}^{+}+6 \mathrm{e}^{-}$

Reação Cátodo: $3 / 2 \mathrm{O}_{2(\mathrm{~g})}+6 \mathrm{H}^{+}+6 \mathrm{e}^{-} \rightarrow 3 \mathrm{H}_{2} \mathrm{O}$

Reação Global: $\mathrm{CH}_{3} \mathrm{OH}_{(\mathrm{l})}+3 / 2 \mathrm{O}_{2(\mathrm{~g})} \rightarrow 2 \mathrm{H}_{2} \mathrm{O}+\mathrm{CO}_{2(\mathrm{~g})}$

Figura 1 -Esquema de funcionamento de uma célula a combustível do tipo SOFC (15)

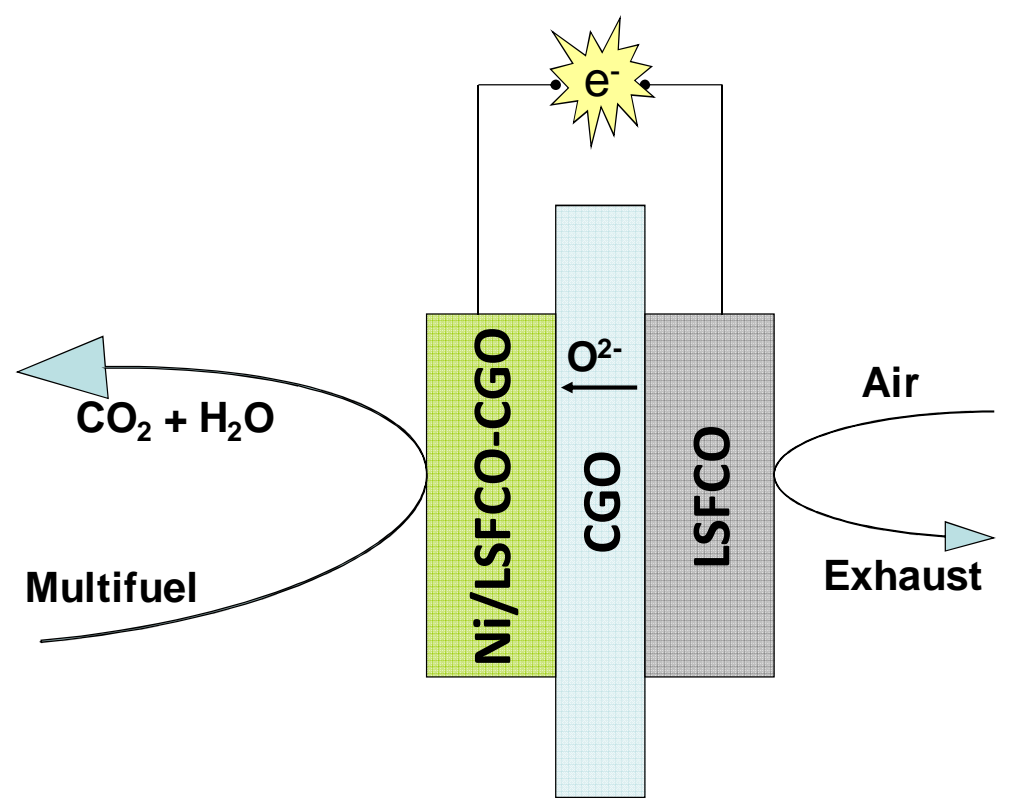




\section{$\underline{\text { Capítulo I }}$}

No ânodo pode-se empregar níquel ou outros catalisadores para quebrar o metanol e criar íons de hidrogênio e de $\mathrm{CO}_{2}$. A zircônia estabilizada com ítria - ZrO2 - (YSZ) é usada como eletrólito. Como todas as células a combustível, o eletrólito de YSZ é condutor de íons, permitindo-lhes passar do ânodo para o cátodo, mas não é condutor de elétrons. A ítria é um sólido, durável e é vantajoso em grandes sistemas industriais. Embora YSZ seja um bom condutor de íons, só funciona em temperaturas muito elevadas. A temperatura de operação padrão é de aproximadamente $950^{\circ} \mathrm{C}$. Operando a célula a combustível em uma temperatura tão alta, facilmente quebra-se o metano e oxigênio em íons. A grande desvantagem da SOFC, como resultado da alta temperatura, é que impõe restrições consideráveis sobre os materiais que podem ser usados para interconexões. Outra desvantagem em uma temperatura tão alta é que outras reações indesejáveis podem ocorrer no interior da célula de combustível. É comum que o pó de carvão ou grafite utilizado para construir o anodo impeça que o combustível atinja o catalisador.

\subsubsection{Célula a combustível alcalina ( AFC - Alkaline Fuel Cells)}

A célula de combustível alcalina é um sistema amplamente estudado desde os anos 1970. (16) O entusiasmo por este tipo de célula se explica pela sua cinética de reação de óxido-redução mais rápida do que em meio ácido. A temperatura de funcionamento é da ordem de $60-80{ }^{\circ} \mathrm{C}$ sob pressão atmosférica. Os eletrocatalisadores a base de platina são geralmente utilizados no cátodo sendo níquel utilizado no ânodo; o eletrólito frequentemente usado e solução aquosa de hidróxido de potássio $(\mathrm{KOH})$. Contudo, o funcionamento deste tipo de célula é limitado pela carbonatação e corrosão dos materiais eletródicos. Um dos principais problemas no uso de AFC e que o dióxido de carbono $\mathrm{CO}_{2}$ presente no ar, reage com os íons $\mathrm{OH}^{-}$e $\mathrm{K}^{+}$do eletrólito líquido, formando um precipitado de carbonato de potássio $\left(\mathrm{K}_{2} \mathrm{CO}_{3}\right)$. O CO, igualmente presente no ar, reage no cátodo da $\mathrm{AFC}$ onde e oxidado a $\mathrm{CO}_{2}$ o qual se junta com o dióxido de carbono proveniente do ar para carbonatar o eletrólito. Platina e normalmente utilizada como material do catodo, mas em contato com a solução de $\mathrm{KOH}$ o material acaba sofrendo corrosão. Estes fenômenos de carbonatação e corrosão dos materiais eletródicos contribuem para diminuir a durabilidade das células a combustível alcalinas.

Como já mencionado anteriormente, as AFC são mais frequentemente alimentadas com hidrogênio no ânodo e oxigênio no cátodo, porém, estudos vem sendo feitos com o objetivo de substituir o hidrogênio por um combustível líquido alternativo, sem que haja perda de 


\section{$\underline{\text { Capítulo I }}$}

desempenho da célula. Desta maneira, o estudo da eletrooxidação de combustíveis tais como borohidreto de sódio $\left(\mathrm{NaBH}_{4}\right)$ vem ganhando cada vez mais espaço no meio científico. (17)

Reação ânodo: $\mathrm{H}_{2(\mathrm{~g})}+2 \mathrm{OH}_{(\mathrm{aq})}^{-} \rightarrow 2 \mathrm{H}_{2} \mathrm{O}_{(\mathrm{l})}+2 \mathrm{e}^{-}$

Reação Cátodo: $1 / 2 \mathrm{O}_{2(\mathrm{~g})}+\mathrm{H}_{2} \mathrm{O}_{(\mathrm{l})}+2 \mathrm{e}^{-} \rightarrow 2 \mathrm{OH}_{(\mathrm{aq})}^{-}$

Reação Global: $\mathrm{H}_{2(\mathrm{~g})}+1 / 2 \mathrm{O}_{2(\mathrm{~g})} \rightarrow \mathrm{H}_{2} \mathrm{O}_{(\mathrm{l})}$

Figura 2 - Esquema de funcionamento de uma célula a combustível do tipo AFC (18)



\subsection{3 - Células de carbonatos fundidos (MCFC - Molten Carbonate Fuel Cell)}

O eletrodo é constituído por uma solução líquida de carbonatos de lítio, sódio e/ou potássio. Prometem eficiências elevadas, cerca de $60 \%$ e $85 \%$ com cogeração, operando a temperaturas da ordem dos $650^{\circ} \mathrm{C}$, temperatura necessária para se atingir a condutividade suficiente do eletrólito. As MCFC têm operado com base em hidrogênio, monóxido de carbono, gás natural, propano, biogás, diesel e produtos de gaseificação estimulada do carvão, destinandose a aplicações elétricas. Além de dispensar catalisadores caros e usar vários tipos de combustível tem como grande vantagem e simultaneamente desvantagem a temperatura de operação elevada. A desvantagem é a rápida corrosão e o colapso de componentes devido à temperatura elevada.

As principais vantagens destas células são a tolerância a $\mathrm{CO}$ e $\mathrm{CO}_{2}$; a alta temperatura de operação dispensa o uso de catalisadores compostos de metais nobres para reações eletródicas e a 


\section{$\underline{\text { Capítulo I }}$}

temperatura de operação permite que a reforma de combustíveis seja realizada dentro da célula. Como citado anteriormente, a desvantagem fundamental relaciona-se com a pouca estabilidade química dos materiais empregados na confecção dos módulos em função da elevada temperatura de operação.

Reação ânodo: $\mathrm{CO}_{3}^{2-}+\mathrm{H}_{2} \rightarrow \mathrm{H}_{2} \mathrm{O}+\mathrm{CO}_{2}+2 \mathrm{e}^{-}$

Reação cátodo: $\mathrm{CO}_{2}+1 / 2 \mathrm{O}_{2}+2 \mathrm{e}^{-} \rightarrow \mathrm{CO}_{3}^{2-}$

Figura 3 - Esquema de funcionamento de uma célula a combustível do tipo MCFC

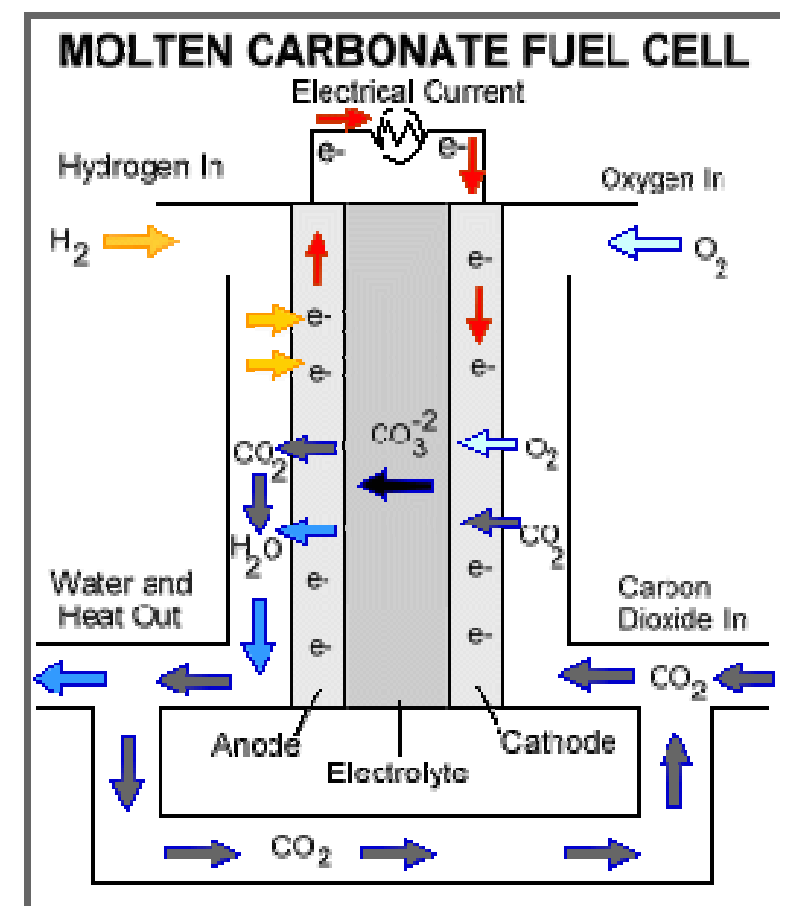

\subsubsection{Células a Combustível de Membrana Trocadora de Prótons (PEMFC)}

É a mais indicada para pequenas plantas estacionárias e veículos automotores, devido à elevada densidade de potência quando o combustível é o hidrogênio $(\sim 1 \mathrm{~kW} / \mathrm{kg})$ e por operar a baixas temperaturas $\left(25\right.$ a $\left.80{ }^{\circ} \mathrm{C}\right)$. (6) Este tipo de célula utiliza como eletrólito uma membrana trocadora de prótons (geralmente um polímero perfluorsulfonado, Nafion ${ }^{\circledR}$, Du Pont), e eletrodos de difusão de gás, constituídos por camadas eletrocatalíticas depositadas sobre meios difusores de reagentes. $\mathrm{O}$ ânodo da PEMFC pode ser alimentado com hidrogênio gasoso ou soluções de álcoois e o cátodo com oxigênio. Utilizando-se $\mathrm{H}_{2}$ no ânodo e $\mathrm{O}_{2}$ no cátodo há uma 


\section{$\underline{\text { Capítulo I }}$}

diferença de potencial teórico ou termodinâmico em circuito aberto de $1,23 \mathrm{~V}$ a temperatura ambiente o que possibilita o aproveitamento de energia como trabalho útil. Os potenciais de trabalho da célula para este sistema (que correspondem à máxima densidade de potência) situamse entre 0,5 e $0,7 \mathrm{~V}$.

A tecnologia das células a combustível, em particular as que utilizam como eletrólito uma membrana de intercâmbio de prótons (proton Exchange membrane fuel cell, PEMFC), apresenta várias vantagens que as tornam atraentes dispositivos para utilização como conversores de energia para aplicações móveis e estacionárias. A parte mais importante da PEMFC é o conjunto membrana-eletrodo (membrane and electrode assembly, MEA), o qual é composto por dois eletrodos de difusão de gás (EDG) separados por uma membrana polimérica. Esses eletrodos são constituídos por uma camada difusora e uma camada catalisadora, esta última contendo em geral, platina (Pt). Os eletrodos de difusão de gás são responsáveis pela catálise das reações eletroquímicas, reação de oxidação de $\mathrm{H}_{2}(\mathrm{ROH})$ e reação de redução de $\mathrm{O}_{2}(\mathrm{RRO})$, e também pela distribuição dos reagentes para os sítios catalíticos. (19) Um esquema do funcionamento de uma PEMFC está representado na figura 4.

Figura 4 - Esquema de funcionamento de uma célula a combustível do tipo PEMFC

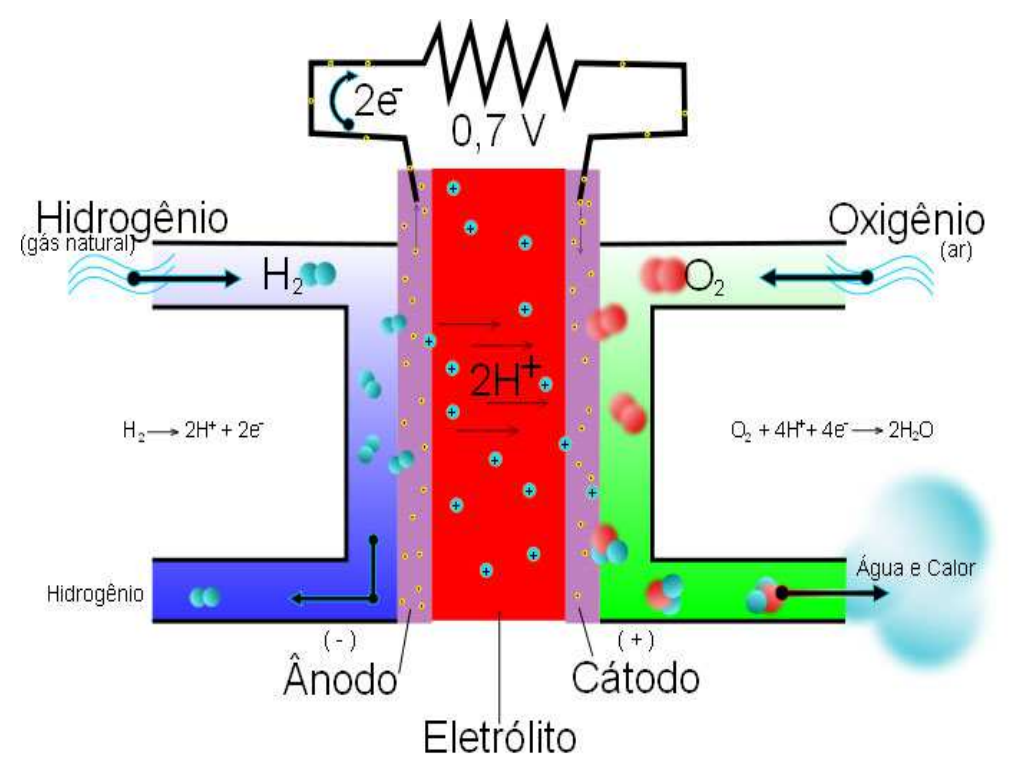

A membrana de Náfion ${ }^{\circledR}$ que consiste de um polímero de tetrafluoretileno, onde em um de seus lados, um éter faz a ligação com um ácido etil sulfônico que se hidrata em contato com a água ou vapor d'água, sendo assim responsável pela condução de prótons e água pela membrana, 


\section{Capítulo I}

sob efeito de um campo elétrico. Este tipo de estrutura combina uma alta estabilidade da cadeia perfluorada (resistência mecânica) com uma extrema hidrofilicidade do grupo sulfônico (alta condutividade protônica (20)).

A aplicação das PEMFCs como fonte primária de energia em residências, veículos elétricos e híbridos, computadores portáteis, telefones celulares etc., tem recebido considerável atenção nos últimos anos. Os progressos no desenvolvimento destes sistemas têm sido impulsionados devido à combinação de avanços significativos de natureza técnica e a implantação de projetos demonstrativos de veículos (utilitários ou passeio) baseados neste tipo de tecnologia.

Este tipo de célula apresenta várias vantagens comparada a outras células a combustível destacando-se as seguintes vantagens:

1) não há líquido corrosivo livre na célula;

2) a manufatura de uma célula é simples;

3) devido à ausência de líquidos livres na membrana, estas células suportam grandes gradientes de pressão;

4) os problemas com corrosão dos materiais que compõem o sistema são mínimos;

5) estes sistemas têm apresentado uma relativa durabilidade.

Em contrapartida, a célula que opera à base de eletrólito polimérico apresenta algumas desvantagens quando comparadas àquelas que operam a maiores temperaturas:

1)os custos da membrana e da célula como um todo, são geralmente maiores comparados aos outros tipos de célula;

2) a administração e gerenciamento de água na membrana é uma condição essencial à operação eficiente;

3) devido à baixas temperaturas de operação, a tolerância a contaminadores, em especial, monóxido de carbono é muito baixa;

4) atualmente não existem garantias de que esse tipo de sistema consiga operar com altos desempenhos, utilizando baixas cargas de catalisador, durante um período que o torne uma fonte energética viável. Sistemas operando em longo prazo com rendimentos aceitáveis precisam ser melhor demonstrados;

5) dificuldade de integração térmica para sistemas que operam associados a reformadores para a produção de hidrogênio. 


\section{$\underline{\text { Capítulo I }}$}

\subsection{Polarização na célula eletroquímica}

A eficiência global da conversão de energia química em trabalho para uma PEMFC operando com $\mathrm{H}_{2} / \mathrm{O}_{2}$ foi melhorada até alcançar valores próximos a 35\%. Em geral, o desempenho de uma célula a combustível e, por consequência, dos seus componentes é dado em função de curvas de polarização, ou curvas da dependência do potencial com a densidade de corrente, conforme apresentada na Figura 1.1. O potencial $\left(\mathrm{E}^{\circ}\right)$ termodinâmico de uma célula é de 1,23 V. Porém, com as perdas existentes, também chamadas de irreversibilidades ou polarizações de operação, o potencial diminui significativamente. $\mathrm{Na}$ célula a combustível estão presentes pelo menos três sobrepotenciais: i) ativação, ii) queda ôhmica e iii) transporte de massa. A polarização por ativação está diretamente relacionada às reações eletroquímicas, ou seja, ocorre quando a reação é controlada pela cinética na superfície do eletrodo. Esta polarização está relacionada principalmente a reação de redução do oxigênio, considerada a reação mais lenta do processo. A polarização por queda ôhmica é decorrente das resistências elétricas impostas pelos eletrodos, eletrólitos e contatos.

Figura 5 Esquema de uma curva de polarização.

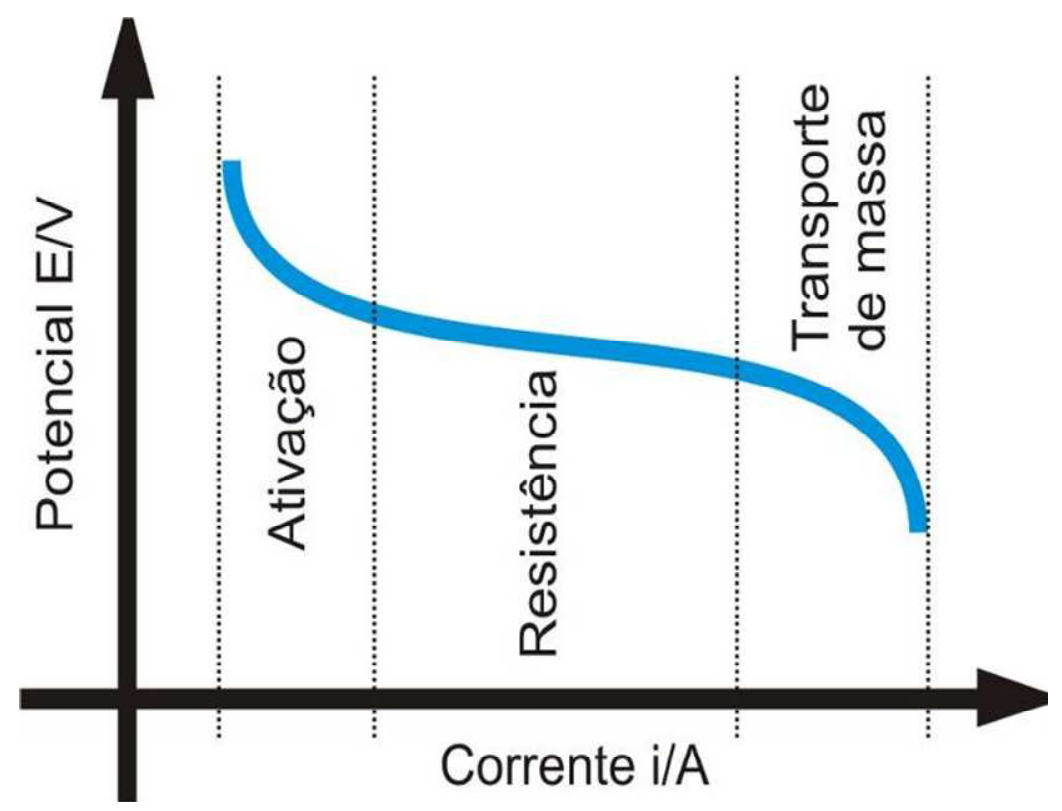

$\mathrm{Na}$ PEMFC a membrana polimérica é a principal responsável por essa resistência, observando-se uma queda do potencial em função da corrente. Essa polarização é governada aproximadamente pela lei de Ohm. Já a polarização por transporte de massa é observada em altas correntes e decorre do esgotamento da espécie reagente na superfície do eletrodo fazendo 


\section{Capítulo I}

com que a velocidade do processo seja determinada pela velocidade de chegada da espécie reagente à superfície. (21)

Outro fator a ser considerado na PEMFC é a umidificação externa dos gases. De uma maneira geral utilizam-se gases umidificados para que não haja queda no desempenho da célula por perda de condutividade da membrana devido à falta de umidificação da mesma. Porém, nas temperaturas usuais da PEMFC isso pode causar um encharcamento dos eletrodos, especialmente no cátodo, onde a água é produzida. Com o aumento da temperatura o gerenciamento da água é facilitado, pois parte da água evapora, sendo mantido apenas o vapor d'água que entra com os reagentes. (22) Considerando que os processos eletrocatalíticos são termicamente ativados é de se esperar que a temperatura exerça influência positiva nas reações eletródicas envolvidas na PEMFC e diminua, portanto, os sobrepotenciais de ativação particularmente o da reação de redução de oxigênio.

\subsection{Eficiência teórica de uma célula a combustível ( $\left.\mathrm{E}_{\text {TEÓRICA }}\right)$}

As células a combustível do tipo PEM, alimentadas com hidrogênio e oxigênio, tem eficiência determinada pela relação entre a energia livre de Gibbs $(\Delta G)$ e a entalpia da reação $(\Delta \mathrm{H})$ :

$\mathrm{E}_{\text {teórica }}=\Delta \mathrm{G} / \Delta \mathrm{H} \quad$ equação 1

$\mathrm{Na}$ equação $1, \mathrm{E}_{\text {teórica }}$ representa a eficiência teórica máxima de uma célula; $\Delta \mathrm{G}$ representa a variação da energia livre de Gibbs (quantidade máxima de energia que pode ser transformada em trabalho elétrico útil) associada a uma reação eletroquímica, e, no caso da reação:

$\mathrm{H}_{2}+1 / 2 \mathrm{O}_{2} \rightarrow \mathrm{H}_{2} \mathrm{O}, \Delta \mathrm{G}$ equivale a $237,1 \mathrm{~kJ}$ para cada mol de água produzida, na forma líquida, a $298 \mathrm{~K}$ e $1 \mathrm{~atm}$ de pressão. $\Delta \mathrm{H}$ representa a variação na entalpia da reação (quantidade de energia total absorvida e liberada em uma reação química) sendo que esta mesma reação gera 285,84 kJ para cada mol de água produzida na forma líquida, a mesma temperatura e pressão. (23)

Contudo, toda essa eficiência não pode ser alcançada devido a polarização de ativação, resistência que a membrana oferece ao transporte dos íons $\mathrm{H}^{+}$resistência ao movimento dos elétrons pelas placas condutoras e pelo circuito externo (ôhmico) e, dificuldade no transporte dos gases reagentes na região de altas correntes (concentração). 


\section{$\underline{\text { Capítulo I }}$}

\subsection{Estabilidade}

O elevado custo dos materiais catalisadores e da membrana/eletrólito é um dos grandes empecilhos para a comercialização das células a combustível tipo PEM. Porém, além do custo, a durabilidade é outro ponto chave a ser superado antes da célula entrar definitivamente no mercado. Até o momento, o tempo de vida operacional para aplicações reais não satisfaz as necessidades de durabilidade exigidas, que é de $5000 \mathrm{~h}$ para carros, $20000 \mathrm{~h}$ para ônibus, e $40000 \mathrm{~h}$ para aplicações estacionárias. $(24,25)$ Para aumentar o tempo de vida da célula do tipo PEM é necessário um profundo entendimento dos mecanismos de falhas de cada componente. $O$ eletrólito utilizado neste tipo de célula é usualmente o $\mathrm{Nafion}^{\circledR}$, uma membrana polimérica composta por uma cadeia de politetrafluoretileno (PTFE) e cadeias laterais de éter vinila com terminações sulfônicas ácidas $\left(\mathrm{SO}_{3} \mathrm{H}\right)$. A presença das cadeias de PTFE confere ao Nafion ${ }^{\circledR}$ excelente estabilidade química e mecânica e os grupamentos sulfônicos conferem condutividade protônica à membrana, comparável a um ácido inorgânico diluído. (26) Entretanto, a condutividade é altamente dependente da quantidade de água presente em sua estrutura. Assim, o grau de hidratação da membrana é fundamental para que o transporte protônico ocorra. A membrana de $\mathrm{Nafion}^{\circledR}$ possibilita que outras moléculas como o oxigênio e alcoóis leves, como o etanol e o metanol, permeiem pela mesma. $(27,28)$ O fenômeno de cruzamento do álcool através da membrana até o cátodo é denominado crossover, sendo este um fenômeno bastante investigado em células do tipo DAFC.(29)

Muitos grupos de pesquisa têm se dedicado à questão de degradação e estabilidade das células a combustível. (30) Como resultado, os estudos realizados apontam vários fatores responsáveis pela queda de desempenho, sendo o principal deles a perda de atividade dos catalisadores na camada catalisadora, que ocorre devido a vários problemas, tais como: corrosão do suporte de carbono, $(31,32)$ perda de catalisador ocasionada por dissolução ou desligamento da partícula catalisadora do suporte (33) e/ou aumento do tamanho de partícula do catalisador devido à sinterização, aglomeração ou redeposição. (34)

Antes de procurar entender os mecanismos de degradação que ocorrem na camada catalisadora, procura-se entender por que os catalisadores sofrem degradação. Dois fatores são apontados como os responsáveis, o primeiro é de origem intrínseca ao catalisador e o segundo relaciona-se às condições de operação da PEMFC. Os catalisadores estão sujeitos à oxidação eletroquímica pelas severas condições de operação, $(35,36)$ um exemplo é o cátodo, está sobre condição fortemente oxidante, elevada quantidade de água, baixo $\mathrm{pH}(<1)$, alta temperatura $(70$ 


\section{$\underline{\text { Capítulo I }}$}

$\left.90{ }^{\circ} \mathrm{C}\right)$, e elevado potencial $(0,6-1,2 \mathrm{~V})$; dentro deste contexto quando a célula a combustível opera fora das condições ideais, como por exemplo, falta de gases reagentes ou com baixa umidificação, os problemas de degradação são ainda mais graves e podem ocasionar danos irreversíveis.

A estabilidade é um requisito fundamental das células a combustível, visando aplicações práticas tanto estacionárias, quanto portáteis. (37) Em geral, este tipo de estudos é realizado mediante estudos chamados "de vida", seguindo-se diferentes estratégias (38): (1) operação a densidade de corrente constante (galvanostático) ou voltagem constante (potenciostático), especialmente adequado para aplicações estacionárias, onde a demanda é mais constante, (2) operação em ciclos sucessivos de liga e desconexão do sistema, com a variante de possíveis mudanças da corrente ou da voltagem, de acordo com as aplicações portáteis. As células a combustível de etanol direto, pelas suas próprias características, principalmente no que se refere à baixa densidade de potência que geralmente apresentam, postulam-se como adequadas para aplicações portáteis, onde, aliás, o uso de um combustível líquido facilita muito o manuseio das mesmas.

\subsection{Degradação do catalisador}

A degradação dos catalisadores envolve dois aspectos: o dos metais catalisadores (usualmente Pt e ligas de Pt) e o do suporte de carbono. Ressalta-se que a degradação de um influencia diretamente a degradação do outro, pois o metal catalisador, em particular a Pt, acelera a oxidação do carbono, e a oxidação do carbono facilita a sinterização da Pt. A aglomeração e o crescimento das partículas também pode ser um dos principais mecanismos da degradação do catalisador na PEMFC. O catalisador à base de Pt usado na PEMFC é de tamanho nanométrico, e é conhecido que nanopartículas apresentam uma forte tendência de se aglomerar devido a sua elevada energia superficial específica. Quanto menor o tamanho da partícula, maior a área superficial específica, e mais fácil para o catalisador se aglomerar e/ou sinterizar. Então quando nanopartículas de Pt aglomeram-se para tornarem-se maiores, a área superficial eletroquímica do catalisador de platina diminui, e consequentemente diminui o desempenho da PEMFC. BORUP et al., (39) examinaram a perda da área superficial ativa do catalisador durante teste em células a combustível e desenvolveram testes acelerados de ciclagem de potencial.

A perda de platina é outro fator importante da degradação da camada catalisadora. Isto pode ser causado por vários fatores tais como a dissolução de Pt, ou mais especificamente no 


\section{$\underline{\text { Capítulo I }}$}

caso de ligas de platina com metais de transição, pode ocorrer a dissolução do material não nobre.

O maior desafio para a utilização de ligas de Pt-M (M = metal de transição) em células a combustível é aumentar a sua estabilidade, principalmente em função do tempo de operação. A dissolução do metal não nobre em meio ácido pode causar uma redução na atividade do catalisador e assim piorar o desempenho da célula. A partir do estudo do mecanismo de perda de catalisador (PtM/C), são propostas pelo menos três causas para a dissolução do metal não nobre nos eletrodos das PEMFCs (22): (i) excesso de metal livre depositado no suporte de carbono durante a preparação da liga, (ii) incompleta ligação deste elemento à Pt devido a baixa temperatura aplicada durante a preparação, (iii) mesmo que um bom grau de liga tenha se formado pode ocorrer desligamento da superfície nas condições de operação da PEMFC, o que leva à formação de uma superfície enriquecida de $\mathrm{Pt}$ uma vez que a liga pode ser termodinamicamente instável nos potenciais da PEMFC e no eletrólito ácido.

\subsection{O Porque do uso do Etanol}

Durante muitos anos o Brasil importou gasolina para sua a frota de veículos. No entanto, em meio a tantas adversidades econômicas enfrentadas no país e com a crise energética global, a busca por fontes alternativas de energia possibilitou que se dirigisse com particular atenção aos álcoois. (40) De toda a produção mundial de etanol, o Brasil juntamente aos Estados Unidos, respondem por $70 \%$ de toda a demanda. A produção de etanol no Brasil está estritamente vinculada ao cultivo da cana-de-açúcar, sendo o produto resultante do processo de fermentação do açúcar.

Atualmente, o etanol é o principal biocombustível renovável obtido a partir da fermentação da biomassa, (41) resultando num processo de carbono neutro. Quando utilizado como combustível esse $\mathrm{CO}_{2}$ volta à atmosfera assim o ciclo do carbono é pouco comprometido e diminui o efeito estufa do planeta. Na célula a combustível a oxidação do etanol gera maior densidade de potência comparada com as máquinas térmicas. A eficiência teórica eletroquímica diminui de $86 \%$ a $70 \%$ na faixa de temperatura de 100 a $1000{ }^{\circ} \mathrm{C}$. A eficiência de Carnot, por sua vez, eleva-se de 0 a $70 \%$ na mesma faixa e somente em temperaturas superiores a $1000{ }^{\circ} \mathrm{C}$ é maior que a eficiência eletroquímica. Portanto, células a combustível a hidrogênio apresentam uma eficiência teórica significativamente maior que máquinas de Carnot, principalmente a baixas temperaturas. 


\section{Capítulo I}

Um grande número de investigações têm se dedicado as células a combustível de etanol direto (direct ethanol fuel cell, DEFC), e vários esforços têm sido dirigidos a superar as suas limitações. (42, 43) No Brasil, o uso direto do etanol como combustível em células é mais conveniente, pois este é produzido em larga escala, possui alta densidade de energia que corresponde a $12 \mathrm{e}^{-}$por molécula na sua eletro-oxidação total, menor volatilidade que o metanol e renovabilidade com alta densidade teórica de energia por massa $\left(8,0 \mathrm{kWh} \mathrm{kg}^{-1}\right)$. O mecanismo geral da reação de eletrooxidação de alcoóis $\mathrm{C} 1$, em termos de sua natureza catalítica, tem como produto final da reação destes combustíveis com oxigênio a produção e dióxido de carbono. Entretanto, a dificuldade de conversão total do etanol a $\mathrm{CO}_{2}$ é o principal problema deste álcool devido à complexidade de ruptura da ligação C-C. (44) A maioria dos trabalhos realizados recentemente envolveram a pesquisa e o desenvolvimento de eletrocatalisadores e membranas para etanol, com progressos significativos alcançados nas últimas duas décadas. (45-47)

As DEFCs apresentam várias limitações. O mecanismo de oxidação do etanol é bastante complexo, e envolve adsorção/oxidação de intermediários etanólicos sobre eletrodos de platina. Estes causam a desativação do eletrodo. Contudo produtos significativos como acetaldeído e ácido acético, são formados como produtos secundários. $(48,49)$ O mecanismo desta reação não é ainda completamente elucidado, por este motivo tem sido relatado que a adição de metais de transição, tais como Sn, para catalisadores à base de Pt promove a oxidação de etanol por adsorção de espécies $\mathrm{OH}$ em potenciais consideravelmente mais baixos em comparação com Pt, permitindo a ocorrência de um mecanismo bifuncional. $(50,51)$ Além disso, o efeito eletrônico causado por um segundo metal sobre os átomos vizinhos de Pt pode levar a um enfraquecimento da ligação de espécies adsorvidas no catalisador bimetálico. (52)

Em uma célula a combustível alimentada diretamente com etanol (DEFC), as seguintes reações deveriam ocorrer nas condições normais de temperatura e pressão (53):

$$
\begin{array}{lll}
\text { Ânodo: } \mathrm{CH}_{3} \mathrm{CH}_{2} \mathrm{OH}+3 \mathrm{H}_{2} \mathrm{O} \rightarrow 2 \mathrm{CO}_{2}+12 \mathrm{H}^{+}+12 \mathrm{e}^{-} & \left(\mathrm{E}_{0}=0,084 \mathrm{~V}\right) & \text { equação 2 } \\
\text { Cátodo: } 3 \mathrm{O}_{2}+12 \mathrm{H}^{+}+12 \mathrm{e}^{-} \rightarrow 6 \mathrm{H}_{2} \mathrm{O} & \left(\mathrm{E}_{0}=1,229 \mathrm{~V}\right) & \text { equação 3 } \\
\text { Total: } \mathrm{CH}_{3} \mathrm{CH}_{2} \mathrm{OH}+3 \mathrm{O}_{2} \rightarrow 2 \mathrm{CO}_{2}+3 \mathrm{H}_{2} \mathrm{O} & \left(\mathrm{E}_{0}=1,145 \mathrm{~V}\right) & \text { equação 4 }
\end{array}
$$

$\mathrm{Na}$ oxidação total do etanol a $\mathrm{CO}_{2}$ tem-se a geração de 12 elétrons por molécula de etanol. 


\section{Capítulo I}

\subsection{Mecanismos da reação de oxidação eletroquímica de etanol em Pt pura}

A oxidação eletroquímica do etanol sobre Pt ainda não está completamente elucidada devido à existência de diferentes rotas de reação cujos rendimentos e produtos dependem do potencial utilizado, da composição, da superfície e da estrutura do eletrodo, da concentração de etanol utilizada, entre outros fatores.(55)

Os possíveis passos para a eletro-oxidação de etanol em solução ácida podem ser resumidos no seguinte esquema de reações paralelas (54):

$$
\begin{array}{ll}
\mathrm{CH}_{3} \mathrm{CH}_{2} \mathrm{OH} \rightarrow\left[\mathrm{CH}_{3} \mathrm{CH}_{2} \mathrm{OH}\right] \mathrm{ad} \rightarrow(\mathrm{R}) \mathrm{ad} \rightarrow \mathrm{CO}_{2} \quad \text { (oxidação completa) } & \text { equação } 5 \\
\mathrm{CH}_{3} \mathrm{CH}_{2} \mathrm{OH} \rightarrow\left[\mathrm{CH}_{3} \mathrm{CH}_{2} \mathrm{OH}\right] \mathrm{ad} \rightarrow \mathrm{CH}_{3} \mathrm{CHO} \rightarrow \mathrm{CH}_{3} \mathrm{COOH} \quad \text { (oxidação parcial) } & \text { equação } 6
\end{array}
$$

Onde (R)ad na equação 5 representa os intermediários adsorvidos na superfície do catalisador. A fragmentação de etanol na superfície do catalisador gera adsorbatos estáveis que têm sido o tema de muitos estudos usando, entre outras, as técnicas de espectroscopia de infravermelho in situ (FTIR) e espectrometria de massa eletroquímica diferencial (DEMS). (55)

Entretanto, existem alguns mecanismos propostos que sugerem a existência de três possíveis rotas de reação distintas e paralelas para a oxidação eletroquímica do etanol em meio ácido:

-Uma que leva diretamente a formação de $\mathrm{CO}_{2}$, a mais eficiente e capaz de gerar 12 elétrons;

-Outra que leva a formação de acetaldeído $\left(\mathrm{CH}_{3} \mathrm{CHO}\right)$ capaz de gerar 2 elétrons, que pode ser oxidado a ácido acético $\left(\mathrm{CH}_{3} \mathrm{COOH}\right)$ gerando mais de 2 elétrons ou oxidado a dióxido de carbono $\left(\mathrm{CO}_{2}\right)$ gerando mais 10 elétrons:

-Outra que pode levar diretamente a ácido acético $\left(\mathrm{H}_{3} \mathrm{COOH}\right)$ gerando 4 elétrons.

Os estudos da eletrooxidação de etanol tem mostrado que a distribuição dos produtos depende acentuadamente da concentração de etanol. Ácido acético e $\mathrm{CO}_{2}$ são os produtos identificados a baixas concentrações de etanol. Para soluções concentradas, a rota de reação que produz acetaldeído torna-se dominante. Camara e Iwasita (54) sugeriram que o baixo rendimento de ácido acético e de $\mathrm{CO}_{2}$ em concentrações altas de etanol provavelmente se deve a disponibilidade limitada de sítios livres para adsorver água, a qual é a espécie doadora de oxigênio no respectivo processo de oxidação, via mecanismo de Langmuir-Hinshelwood.

Segundo estudos de Schmiemann at al., (56) a adsorção de etanol ocorre dissociativamente, ou seja, a qubra da ligação C-C ocorre durante a adsorção. Os resultados das 


\section{$\underline{\text { Capítulo I }}$}

medidas de DEMS com etanol marcado isotopicamente mostraram, que os produtos da remoção oxidativa e redutiva do adsorbato de etanol foram somente $\mathrm{CO}_{2}$ e metano, respectivamente. Os autores concluiram que a espécie adsorvida fortemente é o CO.

Lamy e colaboradores, (57) relataram que os eletrocatalisadores de $\mathrm{PtSn} / \mathrm{C}$ são mais ativos que os eletrocatalisadores $\mathrm{PtRu} / \mathrm{C}$ na oxidação de etanol. Várias composições do catalisador bimetálico $\mathrm{PtSn} / \mathrm{C}$ foram testadas e observou-se atividade maior na oxidação de etanol na faixa de composições atômicas de 10 a $20 \%$ de estanho. A densidade de corrente aumentou e o sobrepotencial da reação de oxidação de etanol decresceu em relação à platina pura. A atividade do eletrodo aumentou e o envenenamento do eletrodo por CO, proveniente do etanol, foi reduzido.

\subsection{Objetivo}

O objetivo principal deste trabalho foi : estudar o desempenho e a estabilidade de um sistema DEFC com base em catalisadores $\mathrm{Pt}_{\mathrm{x}} \mathrm{Sn} / \mathrm{C}$ preparados com diferentes concentrações de agente redutor. Dentro deste objetivo geral, dois foram objetivos específicos deste trabalho:

- Estudar do desempenho de um sistema DEFC baseado em catalisadores $\mathrm{Pt}_{\mathrm{x}} \mathrm{Sn} / \mathrm{C}$ preparados com diferentes composições e concentrações de agente redutor.

- Estudar a estabilidade de um sistema DEFC baseado no catalisador $\mathrm{Pt}_{3} \mathrm{Sn}_{1} / \mathrm{C}$. 


\section{EXPERIMENTAL}

\section{Preparação dos catalisadores}

\subsection{Tratamento do suporte de carbono}

Como suporte dos catalisadores foi utilizado pó de carbono Vulcan XC-72R. O pó de carbono possui cerca de $240 \mathrm{~m}^{2} \mathrm{~g}^{-1}$ de área superficial. (12) Este material possui impurezas que são grupos funcionais alifáticos como $\mathrm{CH}, \mathrm{CH}_{2}, \mathrm{CH}_{3}$ que influenciam negativamente na eletrocatálise. Fez-se tratamento térmico para remover essas impurezas, utilizando-se um forno tubular, com rampa de aquecimento programável através de controladores de temperatura. O carbono foi colocado em cadinho de porcelana e introduzido em um tubo de quartzo suprido por um fluxo constante de argônio. A temperatura foi elevada até $850{ }^{\circ} \mathrm{C}$ permanecendo nessa temperatura durante 5 horas. (58)

\subsection{Preparação dos catalisadores}

Os catalisadores de $\mathrm{Pt}-\mathrm{Sn} / \mathrm{C}$ foram preparados por redução química de precursores metálicos em solução pelo método do ácido fórmico (MAF), (59) um procedimento de síntese de elétrocatalisadores suportados patenteado pelo grupo de Eletroquímica de São Carlos. Foi preparada uma suspensão de carbono Vulcan XC-72R de ácido fórmico e aquecida em banho térmico a $80^{\circ} \mathrm{C}$. Nas sínteses empregou-se ácido fórmico 0,5, 1,0 e 2,0 molar em uma proporção de $60 \%$ de metal sobre carbono. A esta suspensão foram adicionadas as soluções de $0,25 \mathrm{~mol} \mathrm{~L}^{-1}$ de ácido hexacloroplatínico $\left(\mathrm{H}_{2} \mathrm{PtCl}_{6} \cdot 6 \mathrm{H}_{2} \mathrm{O}\right)$ (Aldrich) e aproximadamente $0,1 \mathrm{~mol} \mathrm{~L}^{-1}$ de cloreto de estanho $\left(\mathrm{SnCl}_{2}\right)$ (Merk). Após o término da reação e decantado o precipitado, o sobrenadante incolor foi retirado e o precipitado lavado com água deionizada e posteriormente filtrado e seco por $2 \mathrm{~h}$ a $90{ }^{\circ} \mathrm{C}$.

\subsection{Caracterização física dos catalisadores}

A caracterização física dos catalisadores foi feita por fluorescência de raios X (XRF), difração de raios X (DRX), espectroscopia de fotoelétrons de raios X (XPS) e microscopia eletrônica de transmissão (TEM). 


\section{Capítulo II Experimental}

\subsubsection{Fluorescência de raios $\mathrm{X}$}

As análises de XRF foram realizadas para confirmar a relação atômica $\mathrm{Pt} / \mathrm{Sn}$ e para verificar a ausência de impurezas. A análise foi conduzida em um espectrômetro S4 Bruker AXS Explorer em uma potência de $1 \mathrm{~kW}$ e equipado com uma fonte de $\mathrm{Rh}$ de raios-X, um analisador de LiF 220 de cristal e um colimador divergência 0,12 graus.

\subsubsection{Difração de raios-X}

Para a determinação de parâmetros cristalográficos, como o parâmetro de rede, a, distância entre os núcleos de Pt e tamanho médio dos cristais foi empregada a técnica de difração de Raios-X. (60)

A análise estrutural por difração de raios-X de alta intensidade foi realizada utilizando-se um difratômetro de raios X (DRX) Rigaku Modelo Ultima IV "(Rigaku Corp, Japão) operando com radiação $\mathrm{Cu} \mathrm{Ka}(\lambda=0.15406 \mathrm{~nm})$ gerada a $40 \mathrm{kV}$ e $20 \mathrm{~mA}$. Os difratogramas foram coletados a $3^{\circ} \mathrm{min}^{-1}$ para valores de $2 \theta$ entre 20 e 100 graus.

Com o intuito de se obter o tamanho médio de cristalito, assume-se uma configuração esférica das partículas e utiliza-se a equação de Scherrer, equação 7 (61):

$\mathrm{D}=\mathrm{k} \lambda / \beta \cos \theta$

equação 7

onde: $\mathrm{D}=$ tamanho médio dos cristais na direção do plano de difração; $\mathrm{K}=$ constante de proporcionalidade; $\lambda=$ comprimento de onda da radiação; $\theta=$ angulo de difração; $\beta=$ parâmetros que depende da largura a meia altura do pico de difração.

\subsubsection{Microscopia eletrônica de transmissão (MET)}

A Microscopia Eletrônica de Transmissão foi realizada usando um microscópio Philips CM12 com resolução espacial de $0.2 \mathrm{~nm}$. Para essas análises o porta amostra utilizado foi uma grade de cobre com 0,5 cm de diâmetro recoberta por um filme de carbono. Preparou-se uma suspensão de cada catalisador em 2-propanol, que foi homogeneizada em um sistema de ultrassom. Posteriormente, uma alíquota da amostra foi depositada sobre a grade de cobre. Em média, foram medidas digitalmente cerca de 200 partículas em cada amostra para construção dos histogramas e o cálculo do tamanho médio de partícula. 


\section{Capítulo II Experimental}

\subsubsection{Espectroscopia de fotoelétrons de raios $\mathrm{x}$ (XPS)}

O limite de detecção na técnica de XPS não é, usualmente, superior a $1 \%$ em percentagem atômica, sendo a espessura de análise de $10 \mathrm{~nm}$. Esta é uma técnica muito importante quando se tem por objetivo obter análises quantitativas, bem como, informações sobre ligações químicas dos elementos na superfície. A estimativa das concentrações de elementos é feita a partir do número de fotoelétrons emitidos. O espectro obtido através da técnica de XPS permite obter uma distribuição eletrônica dos átomos superficiais do sólido em análise, permitindo a obtenção de energias características de todos os átomos.

As análises de XPS foram realizadas com o objetivo de identificar as fases de Pt e Sn na superfície dos eletrocatalisadores sintetizados pelo método do ácido fórmico, e assim correlacionar as características superficiais com os resultados eletroquímicos. Os espectros foram obtidos com energias de 58,7 eV para análise elementar (composição) e 11,75 eV para a determinação dos estados de oxidação. A avaliação quantitativa de cada pico foi realizada dividindo a área do pico integrado por fatores de sensibilidade atómicas, que foram calculados a partir da ionização de seções transversais. Os resultados foram interpretados usando a biblioteca on-line implementada no software MULTIPAK PHI 6,1 e o Manual PHI de espectroscopia de fotoelétrons de raios-X. (62) Os experimentos foram realizados usando um espectrômetro Physical Electronics (PHI) 5800-01. Uma fonte monocromática Alka de raios-X foi utilizada a uma potência de $350 \mathrm{~W}$. A pressão na câmara de análise do espectrómetro foi de $1 \times 10^{-9}$ Torr durante as análises. O pico de $\mathrm{Ag} 3 \mathrm{~d}_{5 / 2}$ de uma folha de $\mathrm{Ag}$ foi usado, depois do "sputtering" em argônio, para verificar a calibração da escala de energia de ligação (BE). A avaliação quantitativa de cada pico foi feita dividindo a área do pico integrado por fatores de sensibilidade atômicos, que foram calculados a partir da ionização de seções transversais, a profundidade de escape livre médio de elétrons e as funções de transmissão medidos do espectrômetro.

\subsection{Preparação dos eletrodos para a célula eletroquímica}

Os eletrodos utilizados para experimentos em célula são eletrodos de difusão de gás (EDG) (24) de alta área superficial, constituídos por aglomerados de nanopartículas de platina (ou platina juntamente com outro metal) dispersas em carbono de alta área superficial e Teflon ${ }^{\circledR}$ (politetrafluoretileno). O desempenho de um eletrodo de difusão de gás é governado por fatores intrínsecos relacionados com a eficiência do catalisador utilizado e pelos fatores fenomelógicos ligados à estrutura da camada catalisadora. As partículas do catalisador, o eletrólito e o reagente 


\section{Capítulo II Experimental}

gasoso interagem em uma tripla fase reacional, cujas propriedades podem resultar no aparecimento de fenômenos difusionais ou ôhmicos internos que limitam a eficiência do eletrodo, especialmente em altas densidades de corrente. Estes foram confeccionados contendo duas camadas porosas, a camada difusora colocada em contato com o reagente e a camada catalisadora colocada em contato com a membrana. A camada difusora cumpre as funções básicas de distribuir o gás reagente, facilitar a remoção dos produtos e conectar eletricamente a camada catalisadora aos circuitos externos. Na maioria dos casos, a camada difusora também atua como suporte mecânico do eletrodo. A segunda camada, a camada catalisadora, cumpre a função de promover eficientemente a reação eletroquímica e, conseqüentemente, as características de área eletroquímica efetiva e eletrocatálise são as propriedades mais importantes. Os eletrodos foram preparados com carga de $2 \mathrm{mg}$ de $\mathrm{Pt} \mathrm{cm}^{-2}$ no cátodo e $1 \mathrm{mg}$ de $\mathrm{Pt} \mathrm{cm}^{-2}$ no ânodo.

\subsection{Investigação Eletroquímica}

\subsubsection{Estudo fundamental em camada ultra-fina}

\subsubsection{Voltametria cíclia em meio ácido}

A técnica de voltametria cíclica é uma técnica experimental em que um ciclo de varredura de potencial é imposto ao eletrodo de trabalho e a resposta observada em forma de corrente. Esta técnica possibilita a caracterização in situ da superfície eletródica, tornando-se um instrumento útil para a caracterização de eletrocaralisadores. O estudo eletroquímico dos catalisadores preparados foi realizado utilizando-se um potenciostato AUTOLAB PGSTAT $320 \mathrm{~N}$. Os experimentos foram realizados em temperatura ambiente $\left(26 \pm 1{ }^{\circ} \mathrm{C}\right)$ em uma célula eletroquímica convencional de três eletrodos. Um eletrodo reversível de hidrogênio (ERH) foi utilizado como eletrodo de referência e como contra-eletrodo foi usado uma rede de platina platinizada. Como eletrodo de trabalho foi empregado um eletrodo de camada ultra-fina contendo $28 \mu \mathrm{g}$ de metal $\mathrm{cm}^{-2}$ (63) A preparação do eletrodo consiste na deposição de um pequeno volume de uma suspensão aquosa do catalisador sobre uma superfície de carbono vítreo (área geométrica $=0,196 \mathrm{~cm}^{2}$ ), previamente polida com $\alpha$-alumina $0,3 \mu \mathrm{m}$. A suspensão foi preparada misturando sob a ação de um ultra-som o catalisador, uma solução diluída de Nafion ${ }^{\circledR}$ (Aldrich, 0,05 \% em massa) e 2-propanol. 


\section{Capítulo II Experimental}

\subsubsection{Oxidação de CO adssorvido (Stripping de CO)}

Com o intuito de oxidar uma monocamada de CO adsorvido, realizou-se por 10 minutos a adsorção do gás a um potencial de $20 \mathrm{mV}$, utilizando $\mathrm{CO}$ dissolvido, fez-se a remoção borbulhando um gás inerte (Argônio) por 50 minutos, durante o experimento o potencial manteve-se a $20 \mathrm{mV}$, seguido do início da varredura potenciodinâmica a $20 \mathrm{mVs}^{-1}$ entre os potenciais de 0,05 e $1,0 \mathrm{~V}$.

O stripping de $\mathrm{CO}$, além de fornecer um valor mais preciso de área eletroquimicamente ativa, permite a avaliação da tolerância ao envenenamento, visto que o monóxido de carbono é a principal espécie contaminadora presente na eletro-oxidação de alcoóis em eletrodos a base de Pt.

\subsubsection{Estudo em célula unitária}

Para os estudos em célula unitária, foram empregados eletrodos de difusão gasosa (EDG) por apresentarem boa condutividade eletrônica e elevada área superficial, permitindo um fluxo gasoso com baixa resistência difusional. (64) Para serem utilizados na célula, sobre os EDG foram depositadas as camadas catalíticas, em apenas um dos lados.

\subsubsection{Camada difusora}

A camada difusora é a que mantém contato com os canais de difusão de gás e por onde o gás afluente penetra no eletrodo, difundindo-se para a camada catalítica. (65) A preparação da camada catalítica consiste da deposição quantitativa de uma tinta contendo pó catalisador sobre um lado do EDG. Para preparar a camada difusora, o pó de carbono e uma suspensão de politetrafluoretileno (PTFE) na proporção de 70 e 30\% em massa, respectivamente, e com uma cobertura de $6 \mathrm{mg} \mathrm{cm}^{-2}$ foram divididos igualmente nas duas faces do tecido de carbono. Quantidades apropriadas de pó de carbono e PTFE foram pesadas separadamente em dois béqueres, onde são adicionados cerca de $20 \mathrm{ml}$ de água visando a formação de uma dispersão homogênea. A mistura foi mantida em ultrassom por aproximadamente 10 minutos e posteriormente foi adicionado $\mathrm{H}_{2} \mathrm{SO}_{4} 0,5 \mathrm{~mol} \mathrm{~L}^{-1}$ (gota-a-gota) até que atinjiu $\mathrm{pH}=3$. A diminuição do pH visa a formação de flocos que auxiliam no processo de filtração. Em seguida, a suspensão foi deixada em repouso por cerca de uma hora até a completa sedimentação do material. 


\section{Capítulo II Experimental}

A primeira das suspensões foi depositada por filtração sobre uma das faces do tecido de grafite previamente tratado. O processo de filtragem é repetido até que o sobrenadante (água) se torne transparente e conseqüentemente sem flocos. Em seguida, a segunda suspensão foi depositada do outro lado do tecido, usando procedimento semelhante ao descrito acima. Após a filtragem, o compósito foi tratado em forno a $280{ }^{\circ} \mathrm{C}$ por meia hora para remoção do agente dispersante contido na solução de politetrafluoretileno e finalmente sinterizado a $330^{\circ} \mathrm{C}$ por meia hora em atmosfera de ar.

\subsubsection{Preparação do conjunto membrana-eletrodos (MEA)}

O MEA (do inglês "Membrane Electrode Assembly") é o conjunto formado pelo eletrólito, os dois eletrodos e espaçadores, para compensar a altura dos eletrodos em relação à membrana. Como membrana trocadora de prótons, foi utilizado Nafion ${ }^{\circledR} 117$ que, para ser utilizada na célula a combustível, passou por um tratamento prévio com a finalidade de ativar os sítios de troca protônica. Este tratamento encontra-se descrito na literatura (24) e consiste basicamente em mergulhar a membrana em banhos de ácido nítrico e posteriormente peróxido de hidrogênio, a quente. Após isso, um EDG é colocado de cada lado deste eletrólito sólido, mantendo-se a camada catalítica de cada um voltada para a membrana, com a finalidade de que prótons, ao serem formados no ânodo possam ser transportados pela membrana até o cátodo. Finalmente, para compensar a altura dos EDG sobre a membrana, é utilizado um espaçador de cada lado. Este conjunto é prensado a quente $\left(130{ }^{\circ} \mathrm{C}, 1000 \mathrm{~kg} \mathrm{~cm}^{-2}\right)$ durante dois minutos com o objetivo de unir todos os seus constituintes, e recebe o nome de MEA.

\subsubsection{Montagem da célula}

Inicialmente, o MEA é disposto entre duas placas de grafite, cada uma com canais de difusão gasosa, por onde o gás percorre e penetra no EDG. Além disso, destas placas também saem fios condutores pelos quais é feito o controle do potencial da célula, pois o grafite é um ótimo condutor eletrônico e, neste caso, encontra-se muito próximo dos eletrodos, diminuindo, portanto, as perdas por queda ôhmica. Este conjunto de placas de grafite e MEA é acomodado entre duas placas de alumínio, para facilitar o manuseio da célula e para realizar o controle da corrente elétrica do sistema. Como a membrana de Nafion ${ }^{\circledR}$ deve operar sempre umidificada, todo o gás que penetra pelos canais de difusão gasosa deve estar saturado com água. Para 


\section{Capítulo II Experimental}

satisfazer este propósito utilizaram-se duas garrafas de umidificação: uma para o cátodo e outra para o ânodo, cada uma disposta previamente à respectiva placa de alumínio.

\subsubsection{Sistema de coleta dos produtos de reação}

Para determinar os produtos de reação da DEFC, uma instalação analítica descrita na literatura (66) foi montada. A figura 6 representa o set-up que foi usado para capturar os produtos de saída. Em um primeiro frasco, etanol, ácido acético e acetaldeído, em solução puderam ser diretamente analisados por HPLC. No segundo frasco, o acetaldeído foi transportado por um fluxo de nitrogênio partindo do primeiro frasco e reagindo com um excesso de 0,45\% em peso de 2,4 - Dinitrofenilhidrazina (DNPH) numa solução de HCl 2,0 M. O precipitado cor de laranja foi então solubilizado em acetato de etila e analisado por HPLC. No terceiro frasco, $\mathrm{O} \mathrm{CO}_{2}$ formado foi transportado pelo fluxo de nitrogênio onde reagiu com uma solução de hidróxido de sódio 1,0 M, para formar $\mathrm{CO}_{3}^{2-}$. Os íons de $\mathrm{CO}_{3}^{2-}$, puderam ser detectados por HPLC, devido à formação de um pico negativo.

Figura 6 Conjunto experimental para coleta dos produtos de reação na saída da DEFC.

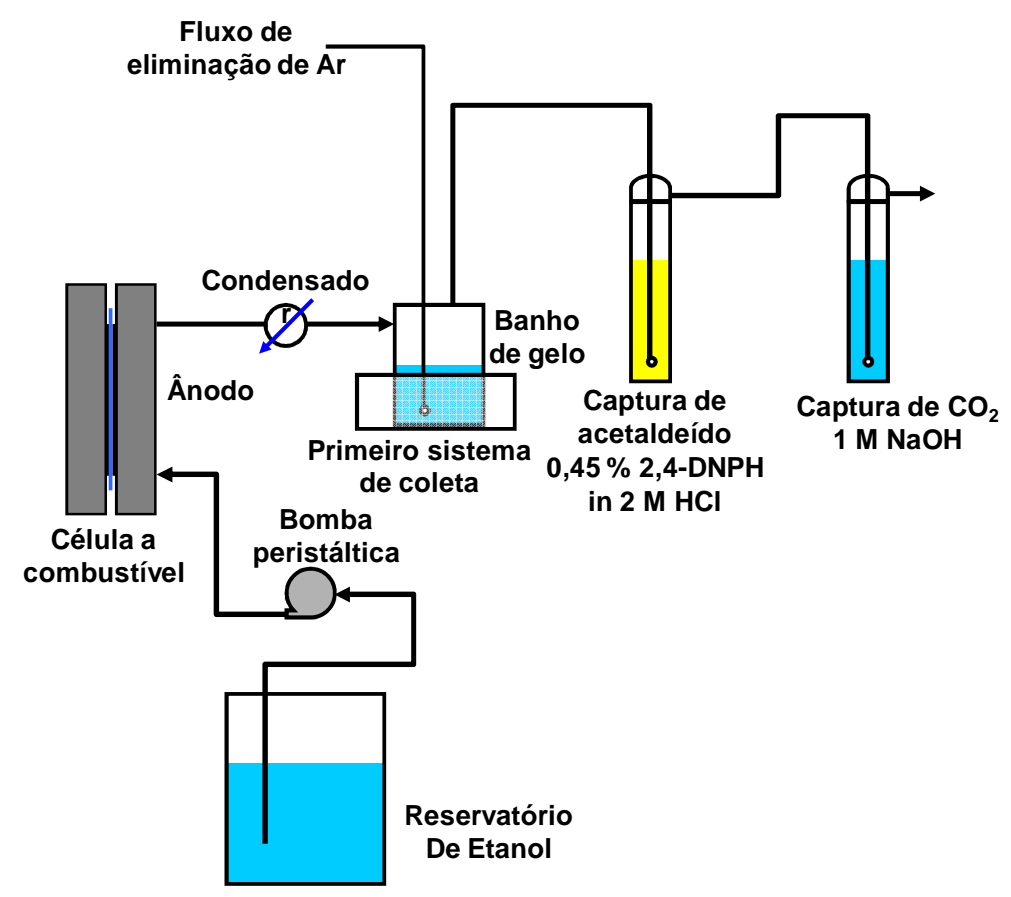




\section{CARACTERIZAÇÃO FÍSICA}

\section{Caracterização físico-química dos catalisadores}

Os padrões de DRX de todos os catalisadores de $\mathrm{PtSn} / \mathrm{C}$ preparados sob diferentes concentrações de agente redutor 0,5M, 1M e 2M, são apresentados nas figuras 7, 8 e 9. Em geral, mostraram os picos característicos da estrutura cúbica de face centrada da Pt cristalina (CFC). O tamanho médio de cristalito foi calculado a partir da equação de Scherrer e da reflexão (2 20 ). Observou-se que, para o catalisador $\mathrm{Pt}_{9} \mathrm{Sn}_{1} / \mathrm{C}$ preparado com 0,5M de ácido fórmico, o tamanho de cristalito é de 4,2 nm, e que para o catalisador $\mathrm{Pt}_{3} \mathrm{Sn}_{1} / \mathrm{C}$ o tamanho de cristalito é de 4,1 nm. Já para o catalisador $\mathrm{Pt}_{1} \mathrm{Sn}_{1} / \mathrm{C}$ preparado nas mesmas condições, o tamanho de cristalito é de 3,5 nm. (67) Os parâmetros de rede dos catalisadores $\mathrm{Pt}_{1} \mathrm{Sn}_{1} / \mathrm{C}$ e $\mathrm{Pt}_{3} \mathrm{Sn}_{1} / \mathrm{C}$ foram de $0.3939 \mathrm{~nm}$ e $0.3958 \mathrm{~nm}$, foram maiores do que os de catalisadores $\mathrm{Pt}_{9} \mathrm{Sn}_{1} / \mathrm{C}$, que apresentou um parametro de rede de $0.3915 \mathrm{~nm}$. Isto indica que houve uma maior incorporação de átomos de $\mathrm{Sn}$ no reticulado cristalino de Pt (68) e consequentemente formação de liga.

Figura 7 Difratogramas de raios $\mathrm{X}$ para $\mathrm{PtSn} / \mathrm{C}$ sintetizados por ácido fórmico 0,5M.

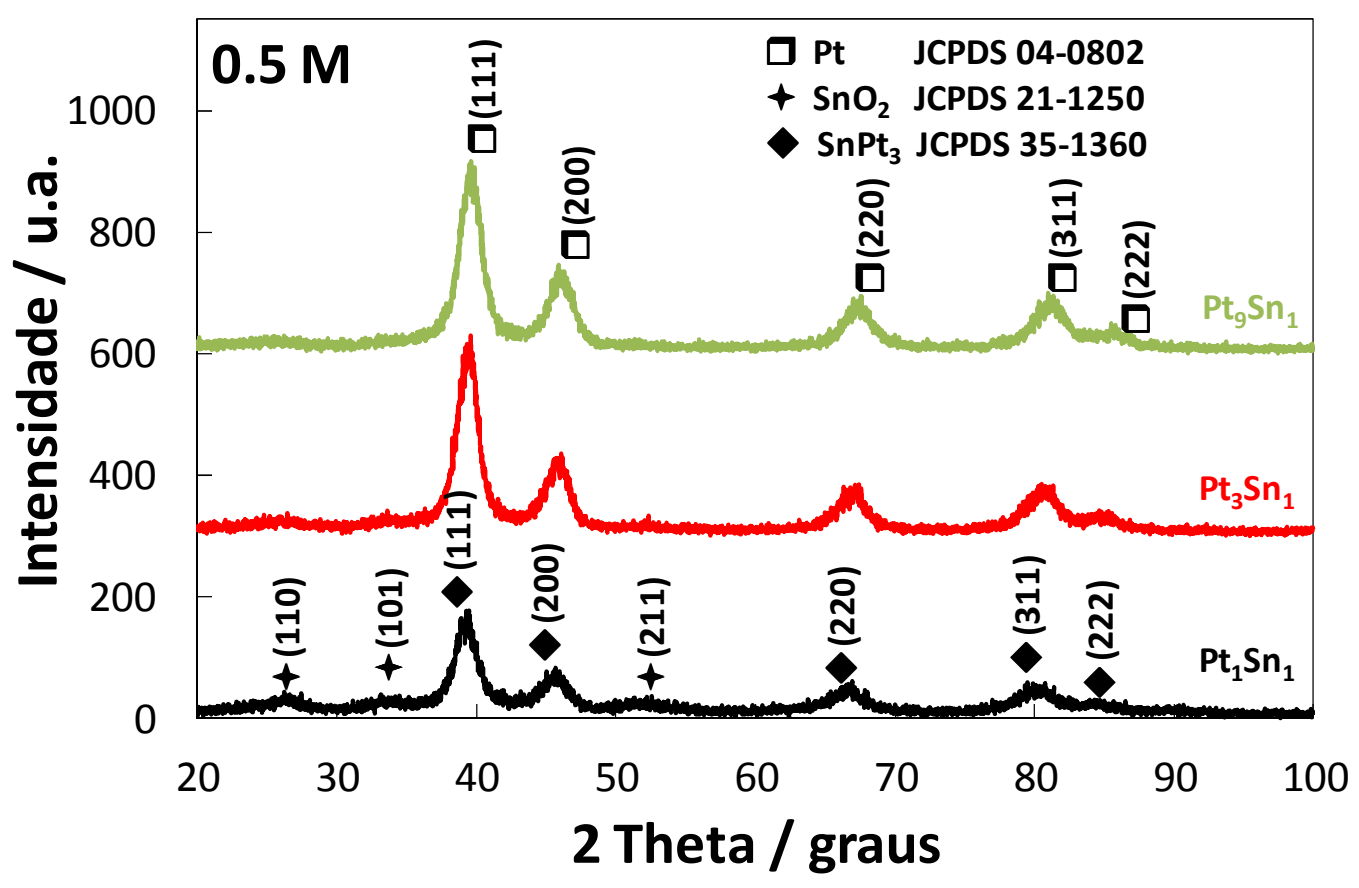


Figura 8 Difratogramas de raios X para PtSn/C sintetizados por ácido fórmico 1M.

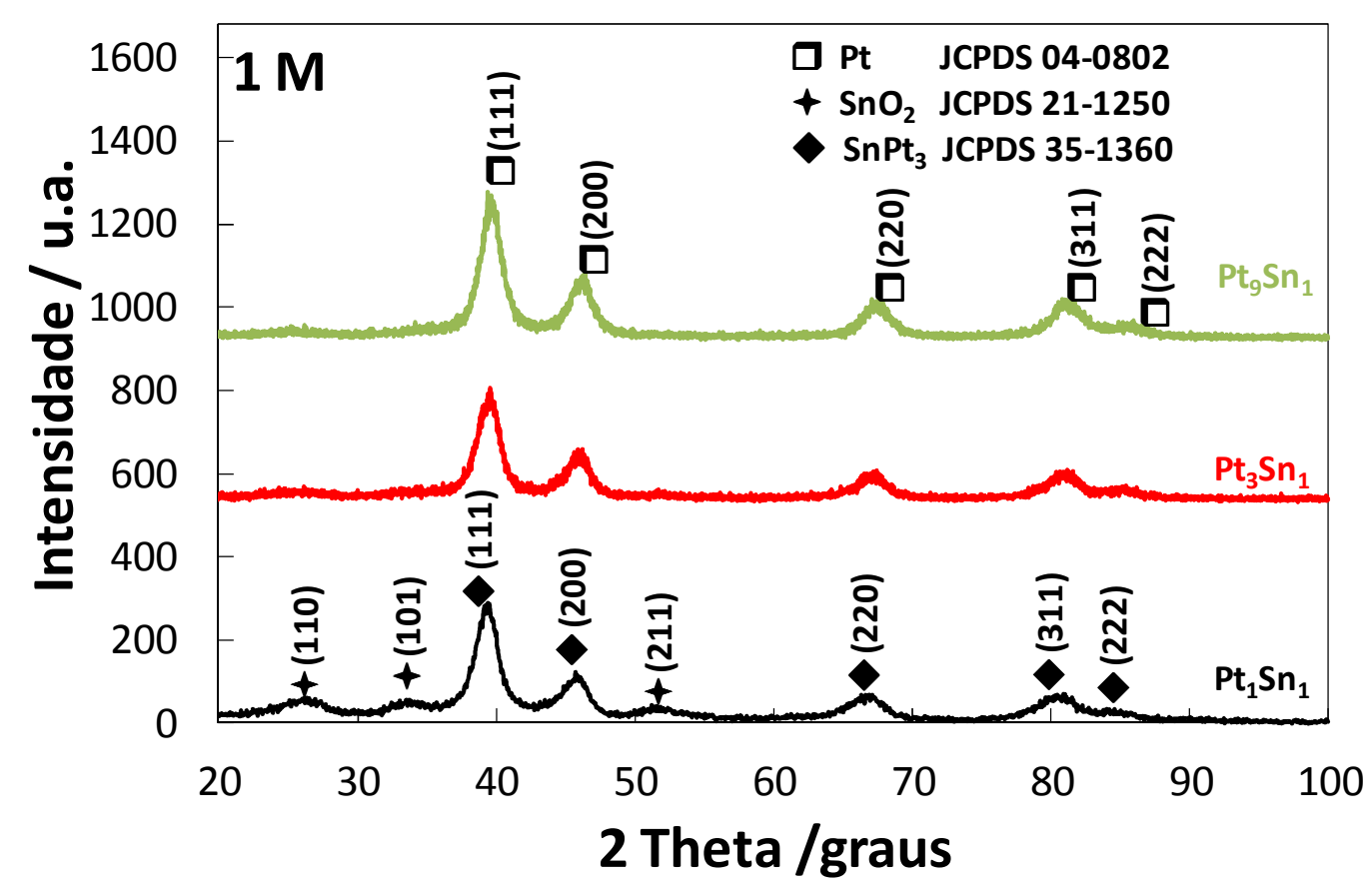

Figura 9 Difratogramas de raios X para PtSn/C sintetizados por ácido fórmico 2M.

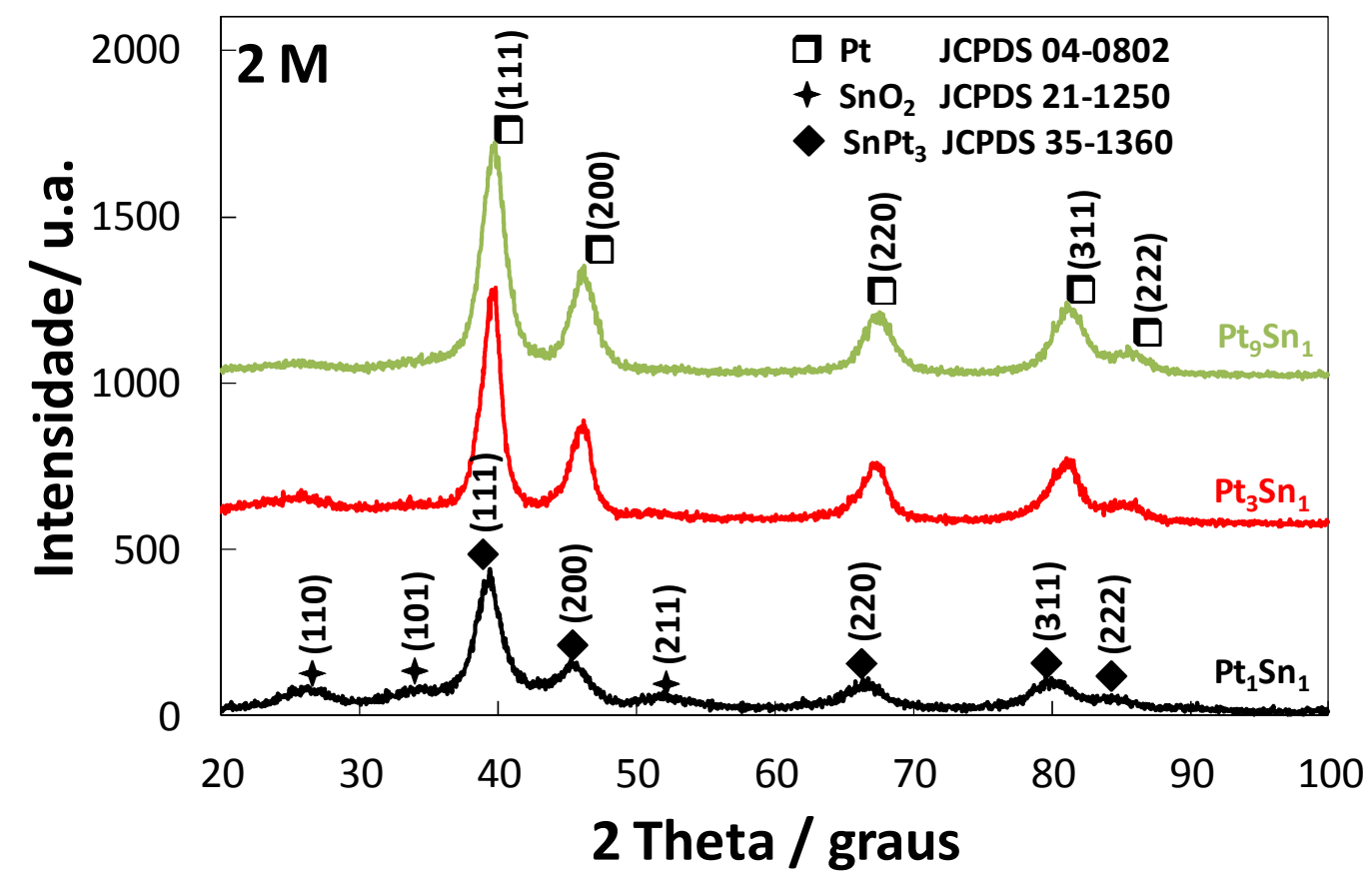




\section{Capítulo III Caracterização Física}

A difração de raios-X é uma técnica importante porque pode ser usada para encontrar as posições relativas dos átomos em um sólido, o que contribui para o entendimento geral da estrutura e as propriedades físicas e químicas. A concentração de agente redutor parece não afetar a estrutura global dos catalisadores de $\mathrm{PtSn} / \mathrm{C}$, bem como o tamanho de cristalito, influenciando somente no grau de liga. Admitindo-se que para os materiais Pt-Sn se cumpre a lei de Vegard pode-se calcular o grau de liga destes materiais e ainda determinar a quantidade de Sn não ligado à Pt. Os valores médios de tamanhos de cristalitos, parâmetro de rede e grau de ligação Pt-Sn estão apresentados na tabela 1.

Tabela 1 Composição química e propriedades estruturais dos catalisadores de $\mathrm{PtSn} / \mathrm{C}$.

\begin{tabular}{|c|c|c|c|c|c|}
\hline $\begin{array}{c}\text { Concentração } \\
\text { Nominal }\end{array}$ & $\begin{array}{c}\text { Composição } \\
\text { Bulk } \\
\text { (XRF) }\end{array}$ & $\begin{array}{c}\text { Parâmetro } \\
\text { de rede } \\
\text { (nm) }\end{array}$ & $\begin{array}{c}\text { Tamanho de } \\
\text { cristalito } \\
\text { XRD (nm) }\end{array}$ & $\begin{array}{c}\text { Tamanho de } \\
\text { partícula TEM } \\
\text { (nm) }\end{array}$ & $\begin{array}{c}\text { Grau de liga } \\
\text { (\%) }\end{array}$ \\
\hline $\mathrm{Pt}_{9} \mathrm{Sn}_{1} / \mathrm{C}-0.5 \mathrm{M}$ & $\mathrm{Pt}_{90} \mathrm{Sn}_{10} / \mathrm{C}$ & 0.3915 & 4.2 & 4.0 & 1.1 \\
\hline $\mathrm{Pt}_{3} \mathrm{Sn}_{1} / \mathrm{C}-0,5 \mathrm{M}$ & $\mathrm{Pt}_{83} \mathrm{Sn}_{17} / \mathrm{C}$ & 0.3958 & 4.1 & 5.0 & 13.4 \\
\hline $\mathrm{Pt}_{1} \mathrm{Sn}_{1} / \mathrm{C}-0,5 \mathrm{M}$ & $\mathrm{Pt}_{54} \mathrm{Sn}_{46} / \mathrm{C}$ & 0.3939 & 3.5 & 3.0 & 7.2 \\
\hline $\mathrm{Pt}_{9} \mathrm{Sn}_{1} / \mathrm{C}-1 \mathrm{M}$ & $\mathrm{Pt}_{91} \mathrm{Sn}_{9} / \mathrm{C}$ & 0.3913 & 4.2 & 3.1 & 0.6 \\
\hline $\mathrm{Pt}_{3} \mathrm{Sn}_{1} / \mathrm{C}-1 \mathrm{M}$ & $\mathrm{Pt}_{76} \mathrm{Sn}_{24} / \mathrm{C}$ & 0.3951 & 4.1 & 4.3 & 11.1 \\
\hline $\mathrm{Pt}_{1} \mathrm{Sn}_{1} / \mathrm{C}-1 \mathrm{M}$ & $\mathrm{Pt}_{53} \mathrm{Sn}_{47} / \mathrm{C}$ & 0.3930 & 3.5 & 5.0 & 4.3 \\
\hline $\mathrm{Pt}_{9} \mathrm{Sn}_{1} / \mathrm{C}-2 \mathrm{M}$ & $\mathrm{Pt}_{90} \mathrm{Sn}_{10} / \mathrm{C}$ & 0.3911 & 3.1 & 4.0 & - \\
\hline $\mathrm{Pt}_{3} \mathrm{Sn}_{1} / \mathrm{C}-2 \mathrm{M}$ & $\mathrm{Pt}_{74} \mathrm{Sn}_{26} / \mathrm{C}$ & 0.3961 & 4.5 & 4.0 & 14.4 \\
\hline $\mathrm{Pt}_{1} \mathrm{Sn}_{1} / \mathrm{C}-2 \mathrm{M}$ & $\mathrm{Pt}_{55} \mathrm{Sn}_{45} / \mathrm{C}$ & 0.3924 & 4.0 & 5.5 & 2.5 \\
\hline
\end{tabular}

A equação usada para calcular o grau de liga é:

$$
\mathrm{x}=\left[\left(\mathrm{a}-\mathrm{a}_{0}\right) /\left(\text { as- } \mathrm{a}_{0}\right)\right] \mathrm{xs} \quad \text { equação } 7
$$

Onde a é o parâmetro de rede da amostra, $a_{0}$ é o parâmetro de rede da platina, as é o parâmetro de rede da liga $\mathrm{Pt}_{3} \mathrm{Sn}$ e xs é a fração de $\mathrm{Sn}$ na amostra.

O grau de liga foi maior nas composições de $\mathrm{Pt}_{3} \mathrm{Sn}_{1}$ em comparação com as amostras de $\mathrm{Pt}_{9} \mathrm{Sn}_{1}$ e $\mathrm{Pt}_{1} \mathrm{Sn}_{1}$. Estanho na forma oxidada $\mathrm{SnO}_{2}$ foi encontrado nas amostras com o maior teor de estanho $\left(\mathrm{Pt}_{1} \mathrm{Sn}_{1}\right)$. Provavelmente, uma grande ocorrência de óxidos na composição 1:1 foi a causa do reduzido grau de liga entre Pt e Sn nessas composições. A presença de óxidos de estanho nos eletrocatalisadores binários é de extrema importância, pois estes poderiam facilitar a oxidação dos intermediários fortemente adsorvidos sobre a superfície de platina. Estes óxidos poderiam resultar numa melhor atividade do eletrocatalisador para as reações estudadas, além do 


\section{$\underline{\text { Capítulo III Caracterização Física }}$}

início da oxidação do combustível ocorrer em menores potenciais quando comparado com platina pura.

\subsection{Caracterização da superfície através de XPS}

Esta técnica de caracterização permite a identificação dos elementos presentes numa dada amostra em análise, O XPS fornece informações sobre a densidade dos estados eletrônicos do catalisador metálico, partindo de pequenas variações nas energias de ligação. A energia de ligação dos elementos está relacionada com o meio em que estão inseridos, podendo-se extrair informação sobre do estado eletrônico do próprio átomo.

A estrutura eletrônica de um metal é modificada pela adição de outros metais, pois estes alteram a tensão do retículo cristalino ou permitem a transferência de carga entre os componentes da liga.

Os espectros de XPS dos catalisadores de PtSn/C em um grande intervalo de energia são apresentados na figura 10. Os espectros revelam os picos dominantes de C, utilizado como suporte; a presença de $\mathrm{O}$, estanho e platina. Foram identificadas as intensidade dos fotoelétrons na amostra em função da energia de ligação que está apresentada na tabela 3. Nos picos são indicados os nomes do elemento correspondentes ao nível eletrônico de onde provém o fotoelétron.

Em geral a Pt é encontrada na valência zero $\left(\mathrm{Pt}^{0}\right)$ e forma iônica $\left(\mathrm{Pt}^{2+}\right.$ e $\left.\mathrm{Pt}^{4 *}\right)$. Na figura 10 pode-se observar os espectros do orbital $4 \mathrm{f}$ da Pt que foram deconvoluídos em dois dubletos. A figura 11 corresponde aos diferentes estados de oxidação da Pt 4f ${ }_{7 / 2}$ e Pt 4f $5 / 2$. A linha com maior intensidade está centralizada em $71,1 \mathrm{eV}$ e pode ser atribuída à Pt de valência zero, no estado metálico, valor bem próximo ao valor listado na literatura. (62) 


\section{Capítulo III Caracterização Física}

Figura 10 Espectros de XPS para $\mathrm{PtSn} / \mathrm{C}$ com diferentes composições atômicas em 0.5M, 1M e $2 \mathrm{M}$ de agente redutor.




Capítulo III Caracterização Física

Tabela 2 Composição atômica superficial derivada dos resultados de XPS. Ao lado da amostra se indica a concentração de ácido fórmico usada na síntese.

\begin{tabular}{|c|c|c|c|}
\hline Amostra & $\begin{array}{c}\text { Conteúdo de Pt na } \\
\text { superfície (\%) }\end{array}$ & $\begin{array}{c}\text { Conteúdo de Sn na } \\
\text { superfície (\%) }\end{array}$ & $\begin{array}{c}\text { Fração metálica de Sn na } \\
\text { superfície (\%) }\end{array}$ \\
\hline $\mathrm{Pt}_{9} \mathrm{Sn}_{1} / \mathrm{C}-0.5 \mathrm{M}$ & 85 & 15 & 2.1 \\
\hline $\mathrm{Pt}_{3} \mathrm{Sn}_{1} / \mathrm{C}-0,5 \mathrm{M}$ & 65 & 35 & 10.5 \\
\hline $\mathrm{Pt}_{1} \mathrm{Sn}_{1} / \mathrm{C}-0,5 \mathrm{M}$ & 25 & 75 & 5.25 \\
\hline $\mathrm{Pt}_{9} \mathrm{Sn}_{1} / \mathrm{C}-1 \mathrm{M}$ & 91 & 9 & 1.8 \\
\hline $\mathrm{Pt}_{3} \mathrm{Sn}_{1} / \mathrm{C}-1 \mathrm{M}$ & 65 & 35 & 5.25 \\
\hline $\mathrm{Pt}_{1} \mathrm{Sn}_{1} / \mathrm{C}-1 \mathrm{M}$ & 35 & 65 & 5.85 \\
\hline $\mathrm{Pt}_{9} \mathrm{Sn}_{1} / \mathrm{C}-2 \mathrm{M}$ & 92 & 8 & 1.28 \\
\hline $\mathrm{Pt}_{3} \mathrm{Sn}_{1} / \mathrm{C}-2 \mathrm{M}$ & 42 & 58 & 13.34 \\
\hline $\mathrm{Pt}_{1} \mathrm{Sn}_{1} / \mathrm{C}-2 \mathrm{M}$ & 27 & 73 & 8.76 \\
\hline
\end{tabular}

\subsection{Deconvolução dos espectros de XPS}

Através da deconvolução de espectros de XPS, mostrada para $\mathrm{Pt}^{0}$ na figura 11 , verificouse a presença de Pt metálica em todas as amostras, a linha com maior intensidade está centralizada em (BE $71 \mathrm{eV}$ ). Os catalisadores preparados com 0,5 M HCOOH mostraram o menor teor de espécies de Pt oxidada (Tabela 2).

Figura 11 Deconvolução de espectros XPS de $\mathrm{Pt}^{0}$ picos na região de energia de ligação de 82-66 $\mathrm{eV}$.

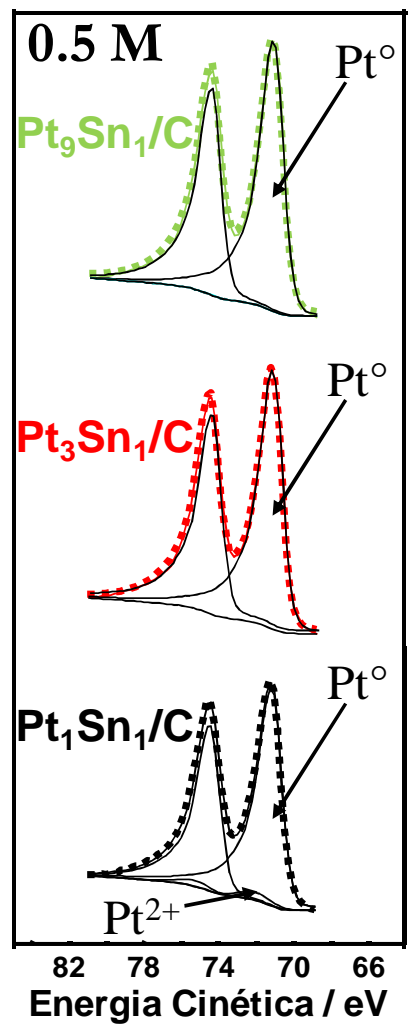

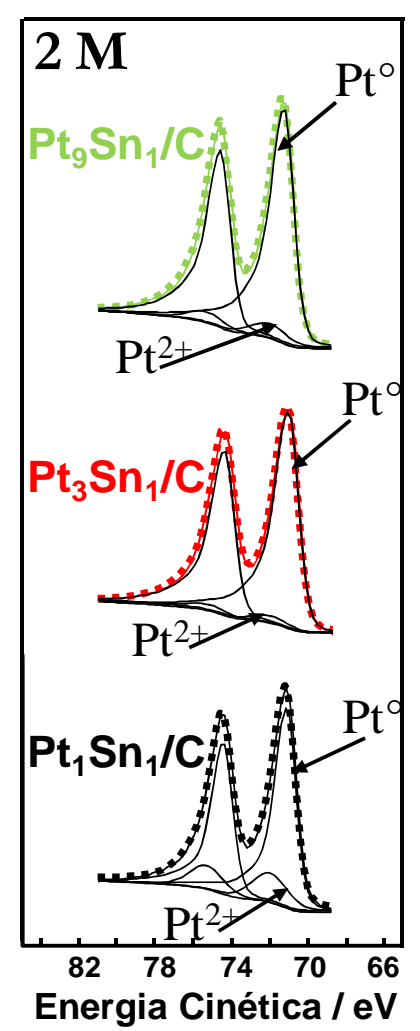


Capítulo III Caracterização Física

Tabela $3 \mathrm{BE}$ e as intensidades relativas de diferentes espécies provenientes dos espectros de XPS nos vários catalisadores de Pt-Sn/C

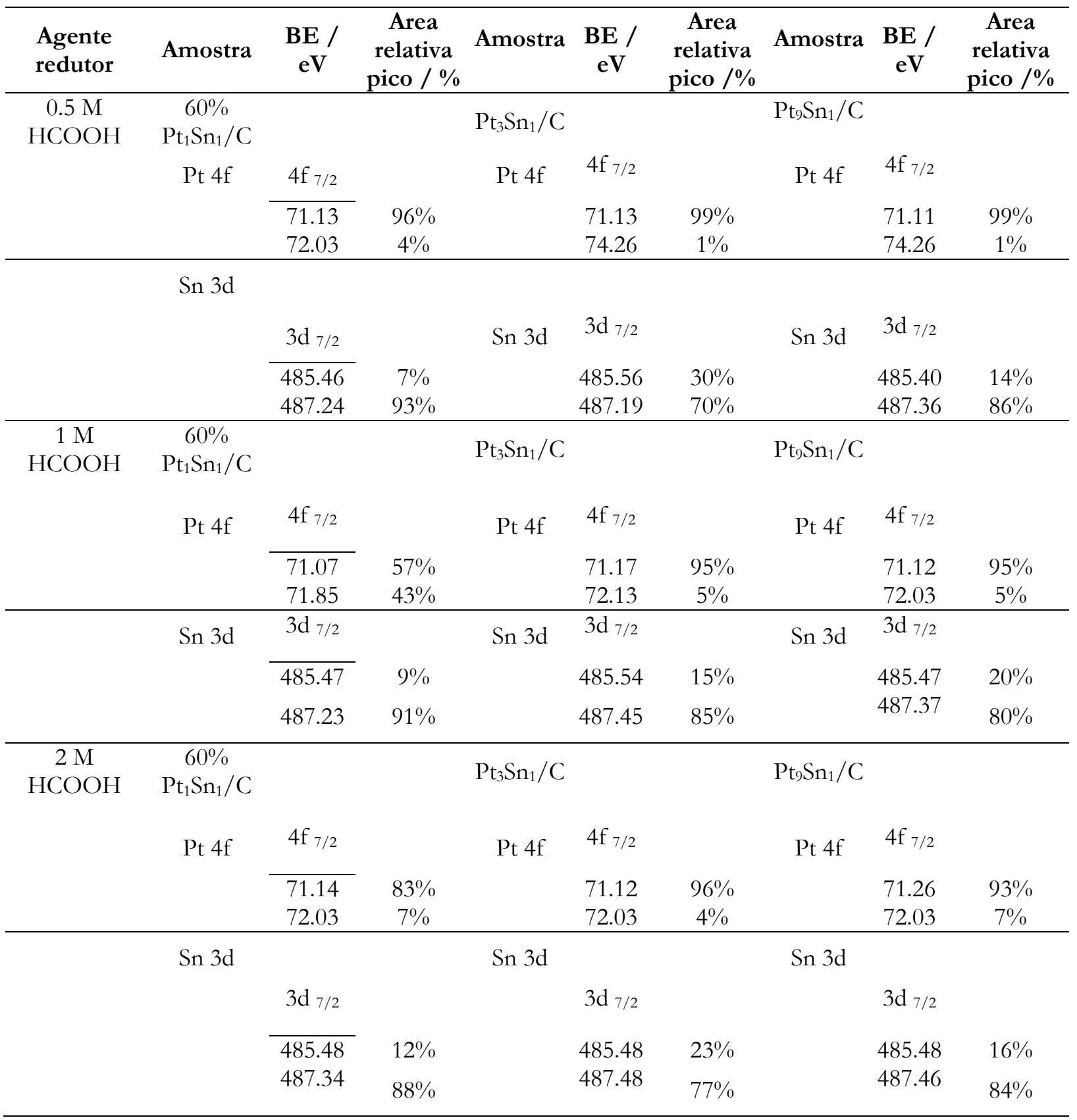




\section{Capítulo III Caracterização Física}

Figura 12 Deconvolução de XPS SN${ }^{4+}$ picos na região de energia de ligação de 500-480 eV.
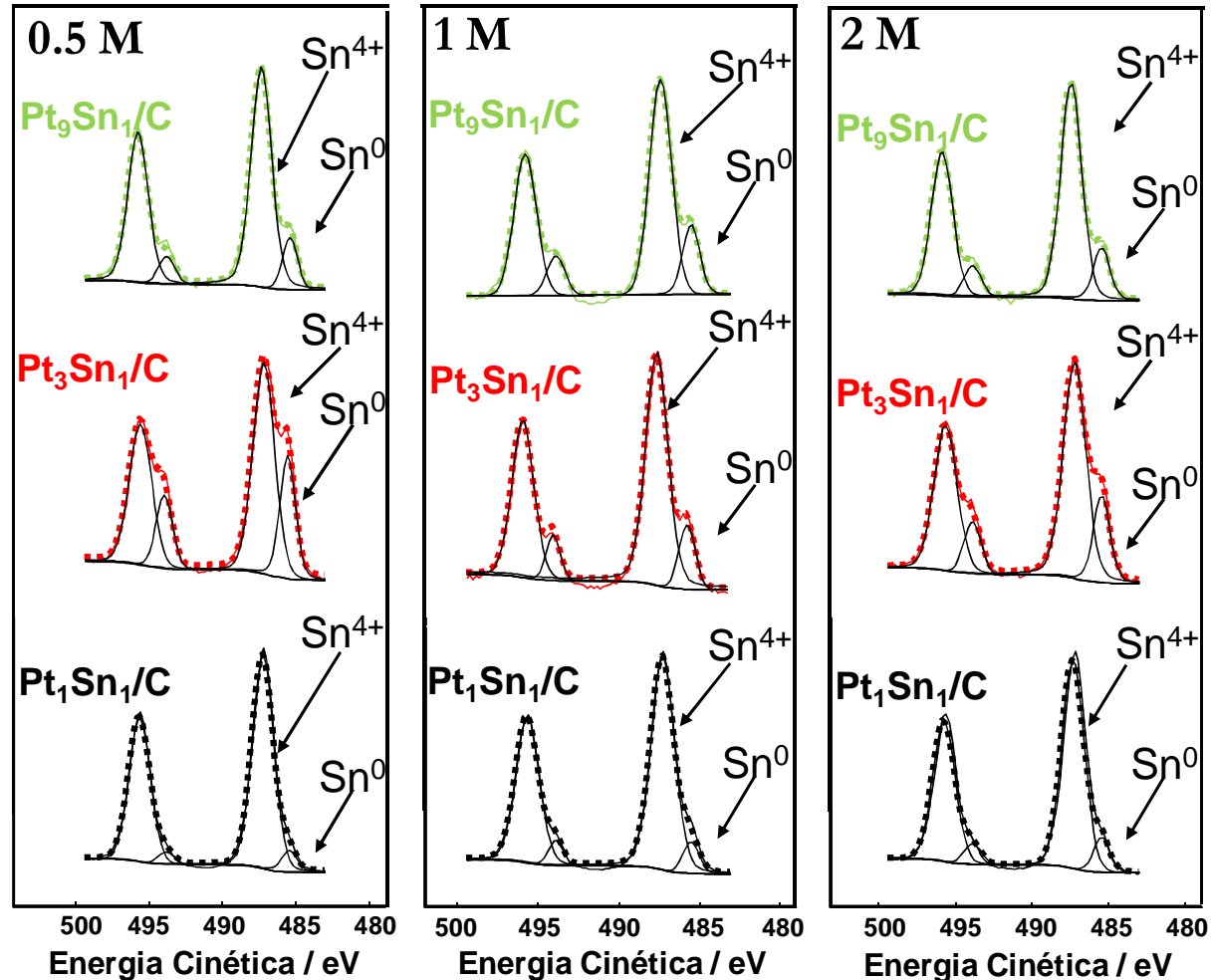

Sn é encontrado na forma oxidada principalmente sobre a superfície (BE $487 \mathrm{eV}$ ) indicando a ocorrência predominante de $\mathrm{Sn}^{4+}$ nas camadas mais exteriores das nanopartículas de catalisador (Tabela 2). No entanto, um percentual adequado de estanho metálico também foi observado $(485,5 \mathrm{eV})$. A fração relativa de $\mathrm{Sn}^{\circ}$ como pode ser vista através da figura 12, pareceu ser influenciada pela concentração do agente redutor apenas para as formulações $\mathrm{Pt}_{1} \mathrm{Sn}_{1}$ que apresentaram o maior conteúdo de estanho. Nas outras amostras, a concentração do redutor $\mathrm{HCOOH}$ não desempenhou qualquer papel relevante.

A presença de Sn na forma de liga foi identificada através da técnica de difração de raios-x e sua ocorrência na camada mais externa foi confirmada por XPS. No entanto, estes resultados devem ser tratados com cautela, pois os átomos de Sn presentes na camada mais superior são facilmente oxidados durante a formação da interface eletrodo-eletrólito. Isto torna difícil a determinação exata da influência da concentração de ácido fórmico sobre o estado de oxidação da superfície.

Vários grupos de pesquisa investigaram a oxidação de etanol em catalisadores de Pt-Sn suportado sobre carbono preparados por métodos de co-impregnação e redução, $(46,79)$ o método de Bonneman $(80,81)$ e um processo modificado por poliol. $(82,83)$ Em todos os casos, a maioria do Sn estava em um estado oxidado não-ligado. 


\section{Capítulo III Caracterização Física}

\subsection{Análise termogravimétrica (TGA) em atmosfera de ar.}

Neste estudo, a técnica de análise termogravimétrica foi usada como ferramenta para determinar a carga metálica presente no eletrocatalisador. (69) A análise evidencia as alterações das propriedades físicas ou químicas da amostra que é monitorada em função do tempo e temperatura, quando a temperatura da amostra é programada.

Figura 13 Perfil de TG-DSC dos catalisadores PtSn /C.
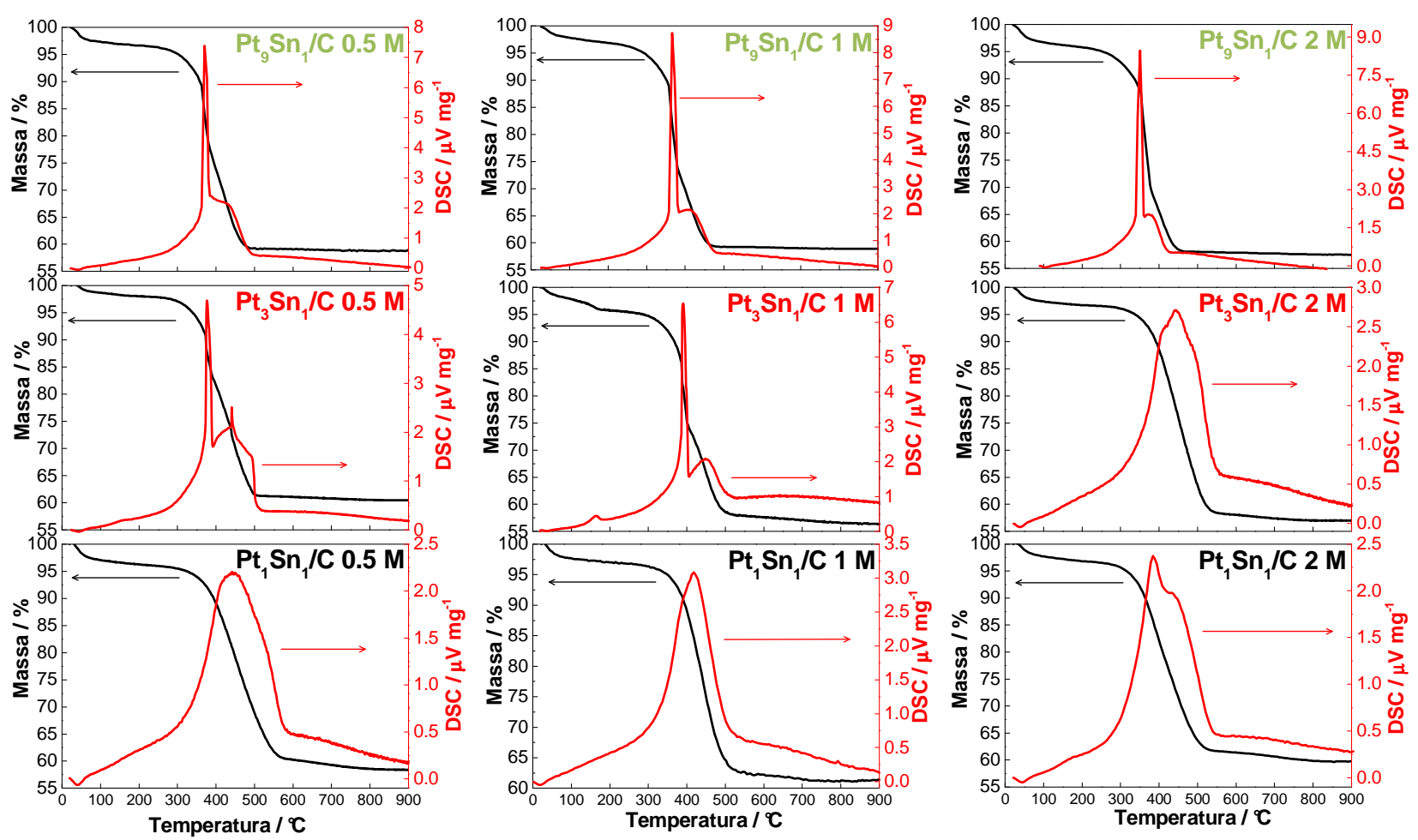

As análises de TG-DSC mostram uma ligeira perda de massa acima de $100{ }^{\circ} \mathrm{C}$ que está associada fisicamente e quimicamente a água adsorvida enquanto que acima de $300{ }^{\circ} \mathrm{C}$ ocorre a decomposição dos grupos funcionais, bem como uma fração amorfa de carbono black. A temperaturas mais elevadas $\left(\sim 450{ }^{\circ} \mathrm{C}\right)$ as camadas de grafeno parcialmente ordenados no carbono black se decompõem para formar $\mathrm{CO}_{2}$ na presença de ar. Em torno de $600{ }^{\circ} \mathrm{C}$ a perda de peso torna-se constante. $\mathrm{O}$ teor de carbono residual queima lentamente até $900{ }^{\circ} \mathrm{C} \mathrm{em}$ ar, até atingir uma perda de peso correspondente ao conteúdo nominal que corresponde a $60 \%$ de metal. 


\section{Capítulo III Caracterização Física}

\subsection{Microscopia eletrônica de transmissão de baixa resolução (MET)}

A técnica de microscopia eletrônica de transmissão foi utilizada para determinar as faixas de distribuição de tamanhos de partículas e avaliar a dispersão destes no suporte de carbono.

A análise das micrografias mostra boa distribuição das nanoparticulas no suporte de carbono para a maior parte dos materias estudados. Os eletrocatalisdores apresentam tamanhos de nanoparticulas entre 3,0 e 5,5 nm observando-se que não houve grande variação no tamanho das partículas.

Figura 14 Micrografias obtidas por microscopia eletrônica de transmissão e histogramas da frequência do tamanho médio de partículas dos eletrocatalisadores de Pt-Sn preparados com $0.5 \mathrm{M}$ de $\mathrm{HCOOH}$.



\section{Capítulo III Caracterização Física}

Através da Figura 14 pôde-se observar a morfologia das partículas. No caso dos catalisadores de $\mathrm{PtSn} / \mathrm{C}$ sintetizados com $0.5 \mathrm{M}$ de $\mathrm{HCOOH}$, obteve-se para o material $\mathrm{Pt}_{9} \mathrm{Sn}_{1} / \mathrm{C}$ um tamanho médio de partícula de $4 \mathrm{~nm}$, para $\mathrm{Pt}_{3} \mathrm{Sn}_{1} / \mathrm{C}$ foi de $5 \mathrm{~nm}$ e, para $\mathrm{Pt}_{1} \mathrm{Sn}_{1} / \mathrm{C} 3 \mathrm{~nm}$, como apresentado na Tabela 1. Os catalisadores dispersos em Vulcan XC72 mostraram boa dispersão para algumas composições e a ocorrência de aglomeração em outras amostras, como no caso do $\mathrm{Pt}_{1} \mathrm{Sn}_{1} /$ C. O crescimento anormal de algumas partículas pode ser devido a uma fraca deposição de Pt sobre o suporte relacionado com o método de preparação e alta concentração de metal. Neste estudo, a melhor dispersão foi obtida para baixos teores de Sn, ao contrário de altas concentrações de Sn onde se obtiveram partículas mal distribuídas mostrando vários graus de aglomeração. Já para elevadas concentrações de Sn, e uma alta concentração do agente redutor (2 M) se obteve uma morfologia uniforme em termos de distribuição e tamanho de partícula. Nenhuma evidencia de cristalinidade foi encontrada, indicando caráter predominantemente amorfo, de acordo com osresultados de DRX.

As morfologias dos catalisadores de PtSn $1 \mathrm{M}$ estão apresentadas na Figura 15, neste caso os catalisadores apresentaram particulas entre 3,0 nm e 5,0 nm, com boa dispersão.

A análise das micrografias mostrou duas características fundamentais dos materiais preparados: primeiro que o método de redução por ácido fórmico produz partículas de diversos tamanhos, sendo que o tamanho de cristalito dos materiais mistos está na faixa de 3 a 5 nm.Também se observa um grande número de partículas pequenas. O segundo ponto a se destacar é o fato dos catalisadores apresentarem uma distribuição não uniforme com a presença de regiões aglomeradas. Estas duas características apresentadas pelos materiais preparados tiveram grande influência no desempenho destes catalisadores frente à reação de oxidação de etanol, como será discutido nos estudos eletroquímicos que serão posteriormente apresentados 
Capítulo III Caracterização Física

Figura 15 Micrografias obtidas por microscopia eletrônica de transmissão e histogramas da freqüência do tamanho médio de partículas dos eletrocatalisadores de Pt-Sn preparados com 1M de $\mathrm{HCOOH}$.
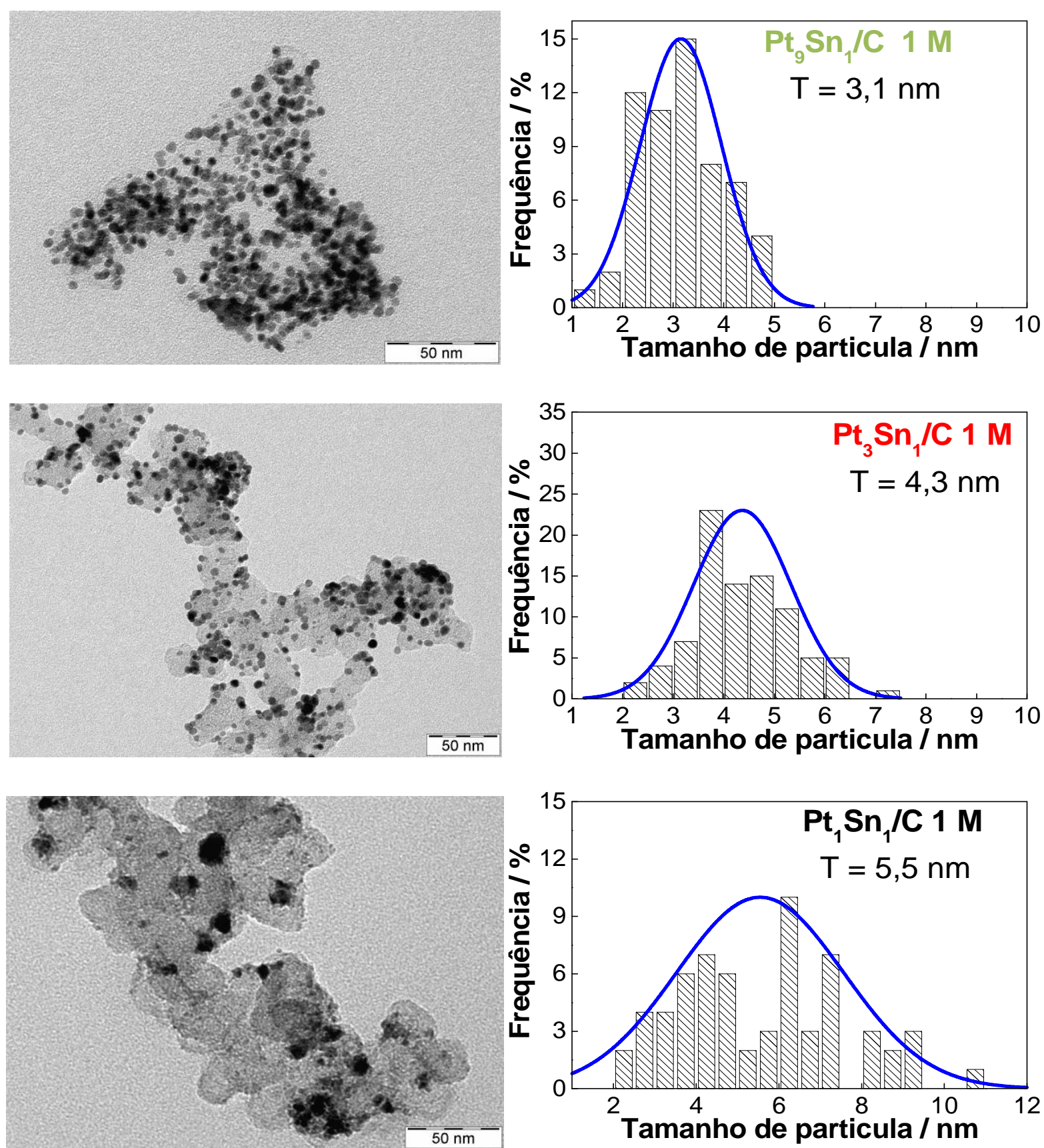


\section{Capítulo III Caracterização Física}

Figura 16 Micrografias obtidas por microscopia eletrônica de transmissão e histogramas da freqüência do tamanho médio de partículas dos eletrocatalisadores de Pt-Sn preparados com $2 \mathrm{M}$ de $\mathrm{HCOOH}$.
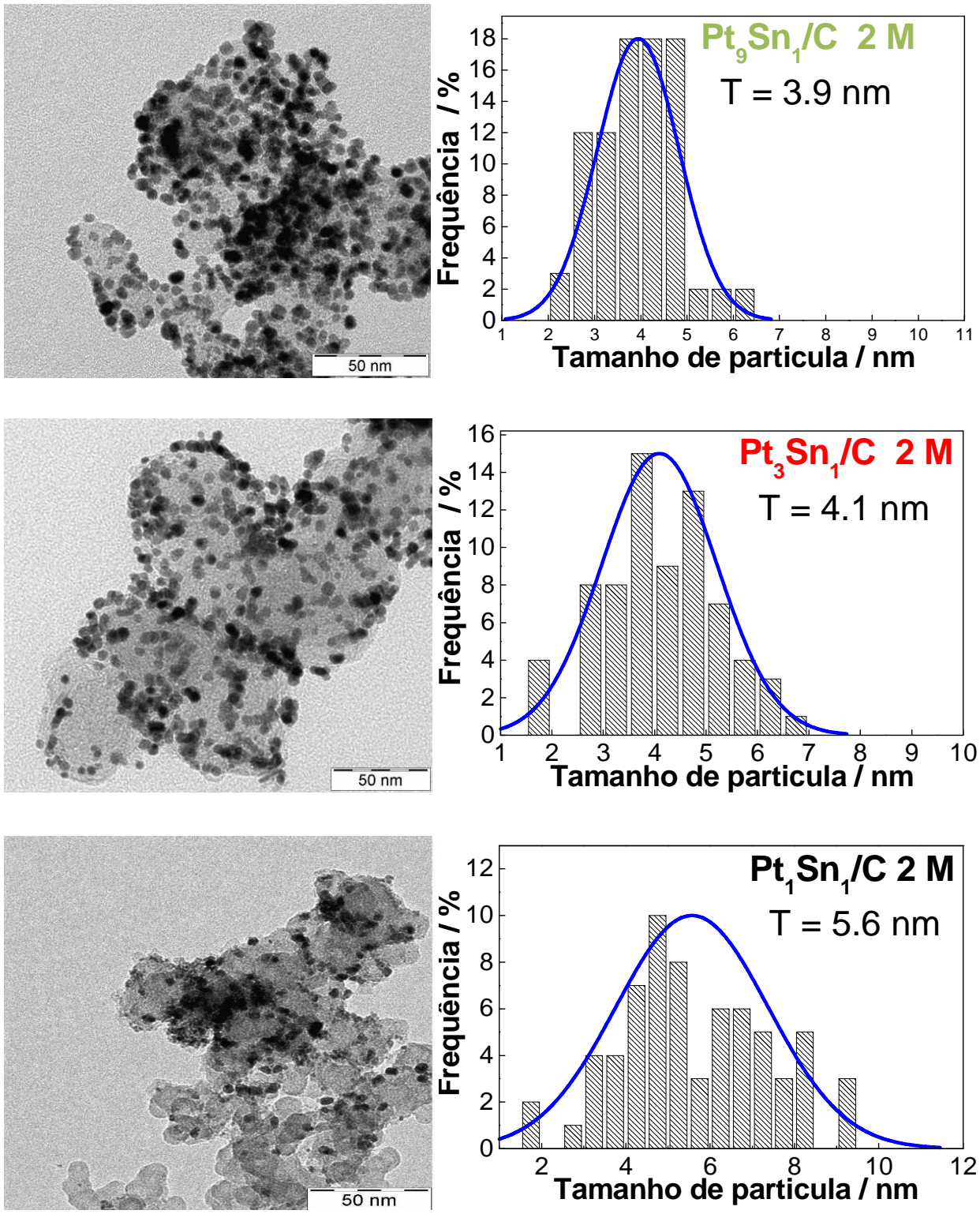


\section{Capítulo IV}

\section{PARTE I - ELETROOXIDAÇÃO DE ETANOL}

\subsection{Reação de eletrooxidação de etanol}

Para se verificar a influência da concentração de ácido fórmico usada no método de preparação dos catalisadores nas características eletroquímicas dos materiais estes foram analisados em duas temperaturas $70{ }^{\circ} \mathrm{C}$ e $90{ }^{\circ} \mathrm{C}$ em célula a combustível de ETOH/O $\mathrm{O}_{2}$ com um fluxo de $2 \mathrm{ml} / \mathrm{min}$. A figura 17 apresenta as curvas de polarização e densidade de potência dos eletrocatalisadores PtSn/C contendo três amostras sintetizadas com $0.5 \mathrm{M}$ de $\mathrm{HCOOH}$.

Figura 17 Curvas de polarização dos catalisadores de PtSn preparados com 0.5M de HCOOH. Catalisadores com $1 \mathrm{mg}$ de $\mathrm{Pt} \mathrm{cm}^{-2}$ no cátodo e $2 \mathrm{mg} \mathrm{de} \mathrm{Pt} \mathrm{cm}^{-2}$ no ânodo.
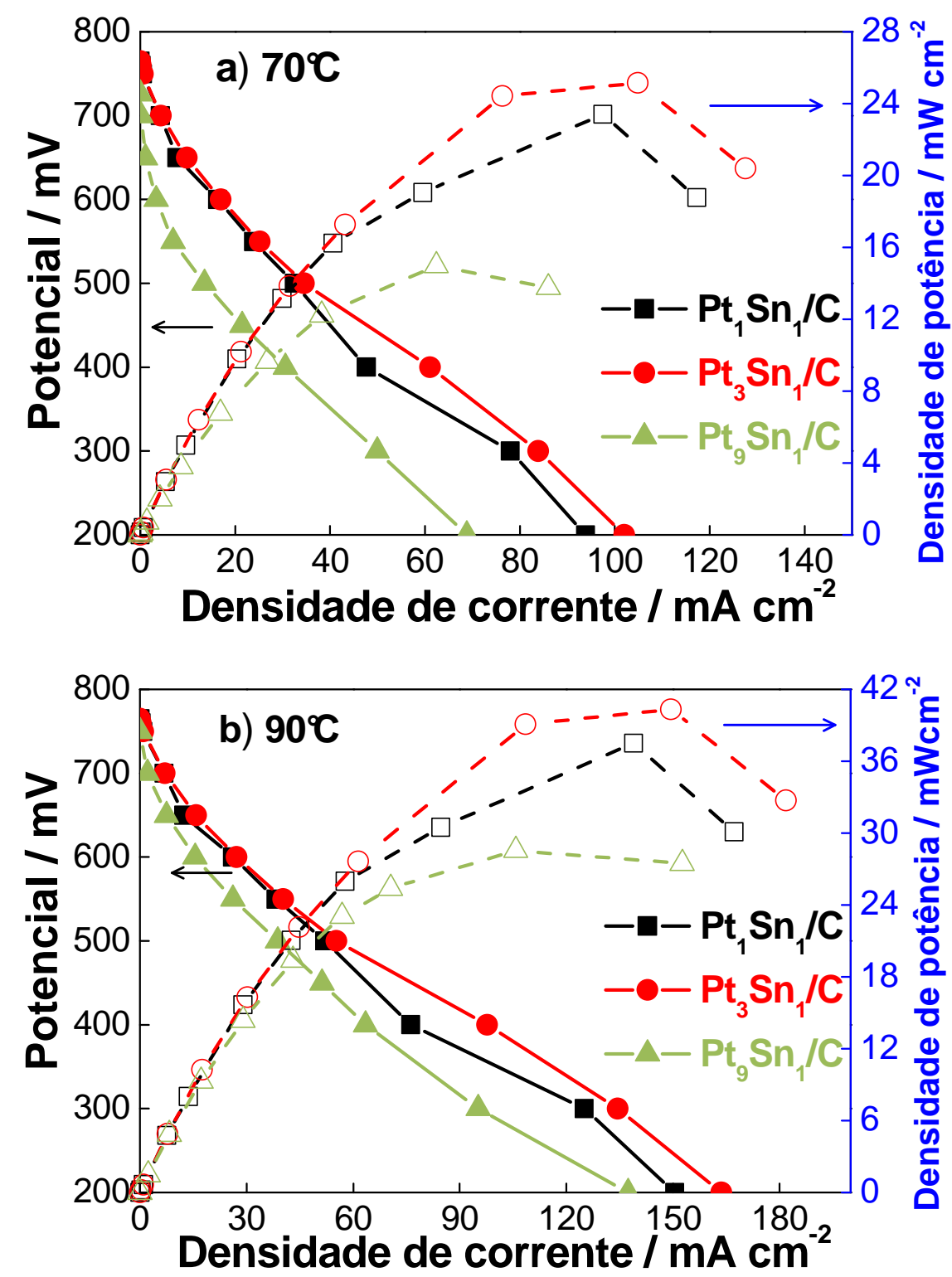


\section{Capítulo IV}

Como se pode observar na figura 17 a $70{ }^{\circ} \mathrm{C}$, os potenciais de circuito aberto (OCV) de $\mathrm{Pt}_{1} \mathrm{~S}_{1} / \mathrm{C}$ e $\mathrm{Pt}_{3} \mathrm{Sn}_{1} / \mathrm{C}$ foram de $0.77 \mathrm{~V}$ e são ligeiramente superiores ao catalisador $\mathrm{Pt}_{9} \mathrm{~S}_{1} / \mathrm{C}$ que foi de $0.66 \mathrm{~V}$. As curvas de polarização em $70{ }^{\circ} \mathrm{C}$ para todos os catalisadores mostraram desempenho inferiores quando comparados aos de $90{ }^{\circ} \mathrm{C}$. O catalisador $\mathrm{Pt}_{3} \mathrm{Sn}_{1} / \mathrm{C}$ e $\mathrm{Pt}_{1} \mathrm{Sn}_{1} / \mathrm{C}$ mostram desempenho superior na região de controle de ativação comparado ao $\mathrm{Pt}_{9} \mathrm{Sn}_{1} / \mathrm{C}$.

A $70{ }^{\circ} \mathrm{C}$ a figura 18 , mostra as curvas de polarização dos catalisadores preparados com $1 \mathrm{M}$ de $\mathrm{HCOOH}$. Observa-se que os materiais $\mathrm{Pt}_{3} \mathrm{Sn}_{1} / \mathrm{C}$ e $\mathrm{Pt}_{1} \mathrm{Sn}_{1} / \mathrm{C}$, apresentam um desempenho superior na região de controle de ativação comparados com $\mathrm{Pt}_{9} \mathrm{Sn}_{1} / \mathrm{C}$.

Figura 18 Curvas de polarização dos catalisadores de PtSn preparados com 1M de $\mathrm{HCOOH}$. Catalisadores com $1 \mathrm{mg}$ de $\mathrm{Pt} \mathrm{cm}{ }^{-2}$ no cátodo e $2 \mathrm{mg}$ de $\mathrm{Pt} \mathrm{cm}^{-2}$ no ânodo.
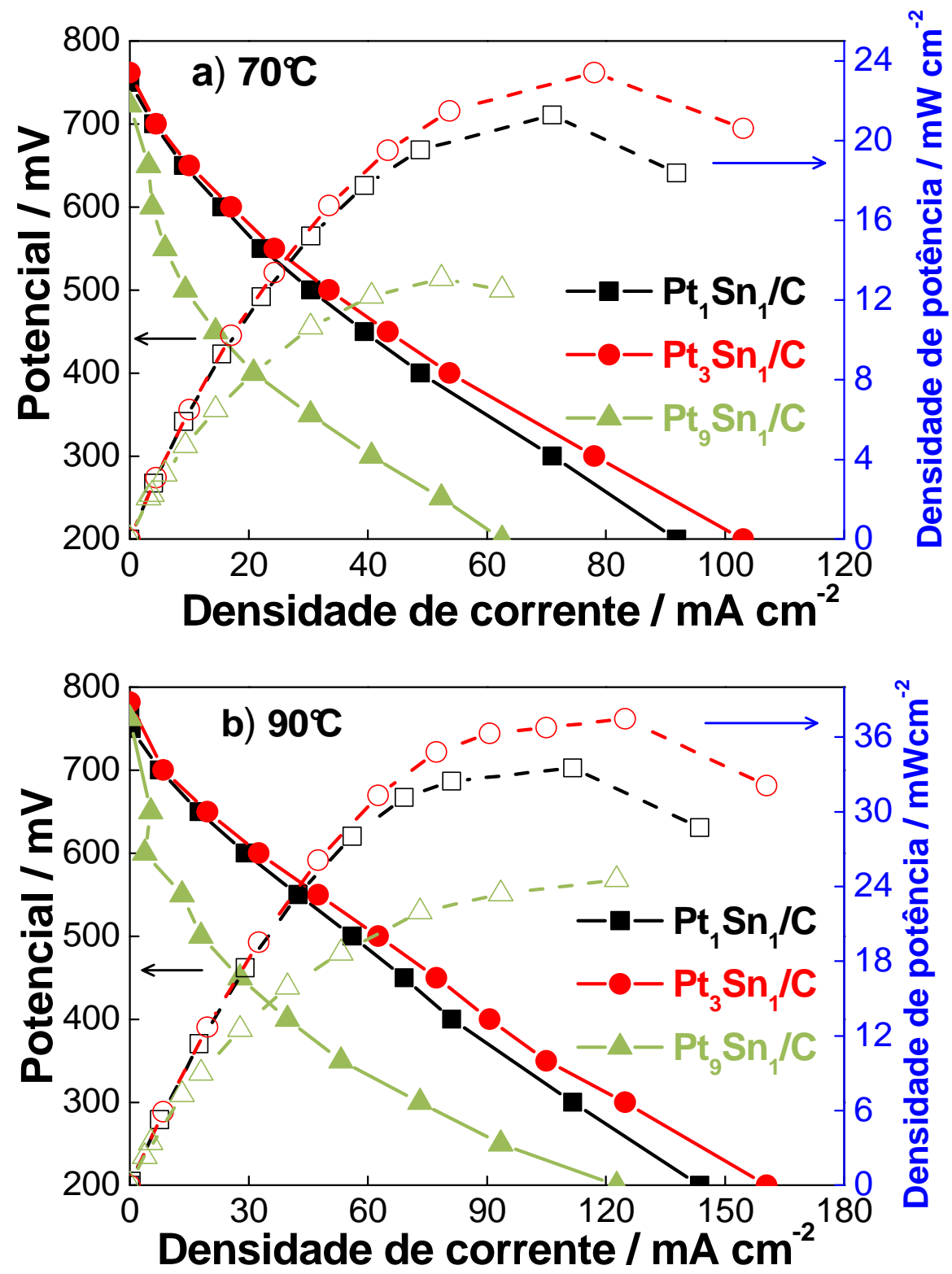
Com o aumento da temperatura, a cinética de oxidação de álccois e a redução de oxigênio é favorecida, a densidade máxima de potência foi de $26 \mathrm{mWcm}^{-2}$ em $70{ }^{\circ} \mathrm{C}$ e de $41 \mathrm{mWcm}^{2}$ a 90 ${ }^{\circ} \mathrm{C}$ para o catalisador $\mathrm{Pt}_{3} \mathrm{Sn}_{1} / \mathrm{C}$. Algumas investigações mostraram que a melhora da reação de oxidação etanol (ROE) foi devida à modificação da estrutura da Pt pela presença de Sn, como por exemplo através da presença de fases PtSn na liga. (49) A eletro-oxidação de alcoóis em meio ácido (isto é, no caso de células de combustível de membrana de troca protônica) necessita da presença de platina, para quebra da ligação C-H e no caso específico de etanol para quebra da ligação C-C. A densidade máxima de potência foi de $24 \mathrm{mWcm}^{-2} \mathrm{em}$ uma temperatura de $70{ }^{\circ} \mathrm{C}$ e $36 \mathrm{mWcm}^{-2}$ a $90{ }^{\circ} \mathrm{C}$. A $90{ }^{\circ} \mathrm{C}$ o desempenho eletroquímico mostra-se melhor. Isto foi confirmado em todos os confrontos $0,5 \mathrm{M}, 1 \mathrm{M}$ e $2 \mathrm{M}$, primeiramente porque trabalhando a temperaturas mais elevadas, a reação ocorre com mais facilidade devido ao favorecimento da cinética.

A figura 19, apresenta as curvas de polarização e densidade de potência dos eletrocatalisadores $\mathrm{PtSn} / \mathrm{C}$ com composições distintas no ânodo da célula preparadas com $2 \mathrm{M}$ de $\mathrm{HCOOH}$. Os catalisadores estudados nesta fase mostraram-se menos ativos que os estudados na fase anterior, o aumento da concentração de agente redutor durante a preparação do catalisador, provoca alterações significativas na razão global $\mathrm{Sn} / \mathrm{Pt}$ sobre a superfície, como observado pelas análises de XPS. Relatou-se na literatura que os catalizadores de PtSn/C com a maioria do Sn no estado oxidado não-ligado poderiam fornecer a promoção notável do desempenho do ânodo de células combustíveis de álcool direto. (70-72) No presente caso, a amostra exibe uma grande quantidade de $\mathrm{Sn}$ metálico na região perto da superfície, isto é, $\mathrm{Pt}_{3} \mathrm{Sn}_{1}$ reduzido com $2 \mathrm{M}$ de $\mathrm{HCOOH}$, é a que mais se identifica na série $2 \mathrm{M} \mathrm{HCOOH}$, mas não na lista geral de catalisadores. Provavelmente, a razão menos favorável de $\mathrm{Pt} / \mathrm{Sn}$ na superfície para este catalisador específico desempenha um papel negativo na reação estudada. 
Figura 19 Curvas de polarização dos catalisadores de $\mathrm{PtSn}$ preparados com $2 \mathrm{M}$ de $\mathrm{HCOOH}$, catalisadores com $1 \mathrm{mg}$ de $\mathrm{Pt} \mathrm{cm}{ }^{-2}$ no cátodo e $2 \mathrm{mg} \mathrm{de} \mathrm{Pt} \mathrm{cm}^{-2}$ no ânodo.
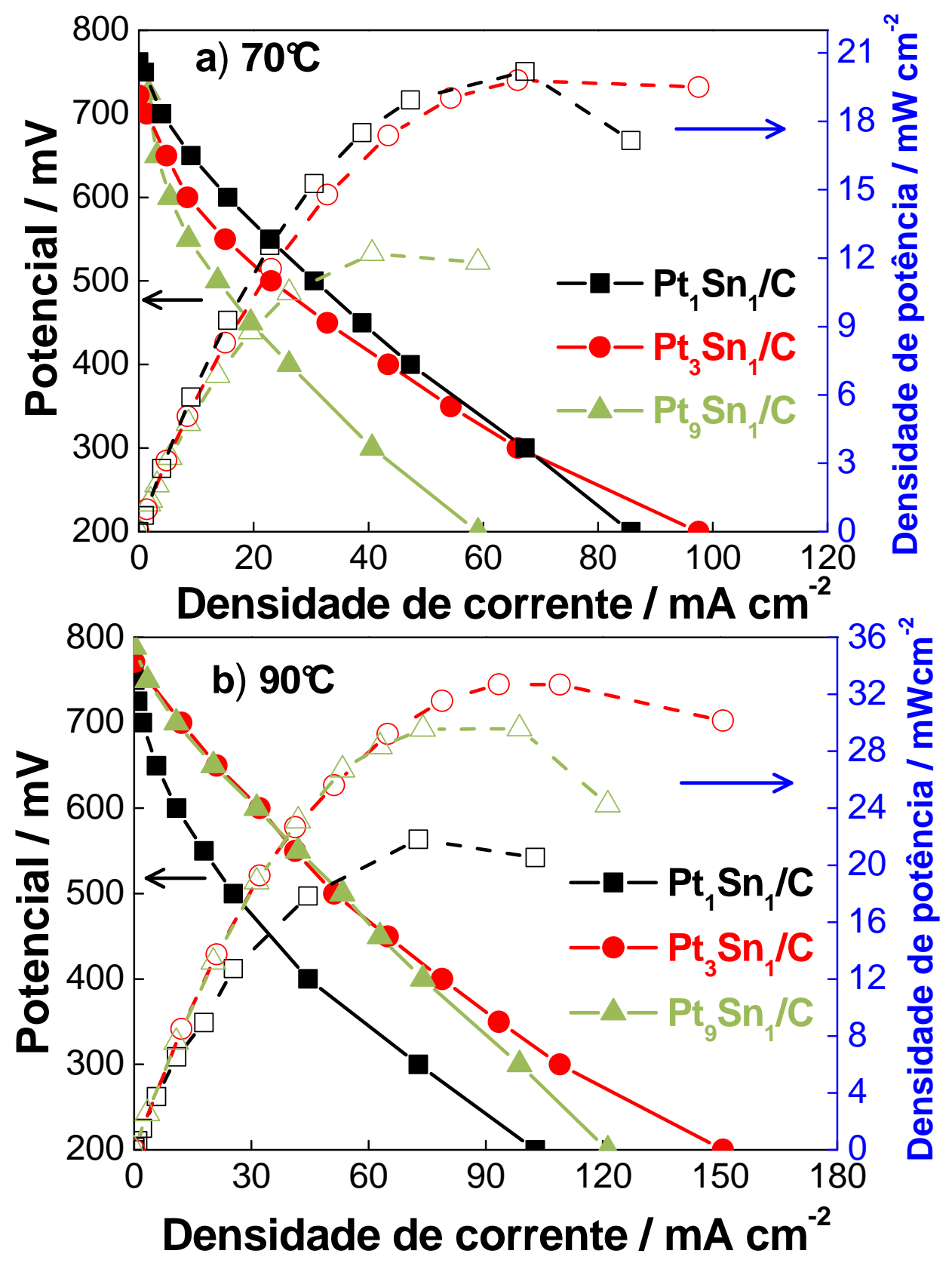

Curvas de voltametria de varredura linear foram realizadas com a célula a combustível alimentada com solução de etanol no ânodo e com hidrogênio no cátodo. Com esse sistema o ânodo opera como eletrodo de trabalho e o cátodo opera como eletrodo de referência reversível de hidrogênio e como eletrodo auxiliar ao mesmo tempo. (73) O eletrodo de trabalho foi submetido a varredura de potenciais desde 5 a $600 \mathrm{mV} \mathrm{a} 10 \mathrm{mV} \mathrm{s}^{-1}$ a fim de verificar o potencial 


\section{Capítulo IV}

de início da oxidação do álcool nos diferentes materiais preparados. $\mathrm{Na}$ figura 20, são apresentadas as voltametrias de varredura linear parar os materiais preparados com $0,5 \mathrm{M}$ de $\mathrm{HCOOH}$.

Figura 20 Voltametria de varredura linear dos materiais Pt-Sn preparados com 0,5M de $\mathrm{HCOOH}$, eletrodos com $1 \mathrm{mg}$ de $\mathrm{Pt} \mathrm{cm}^{-2}$ no cátodo e $2 \mathrm{mg}$ de $\mathrm{Pt} \mathrm{cm}^{-2}$ no ânodo, célula alimentada com etanol $1 \mathrm{~mol} \mathrm{~L}^{-1}$ a $2 \mathrm{ml} \mathrm{min}^{-1}$ no ânodo e hidrogênio no cátodo. $\mathrm{V}=10 \mathrm{mV} / \mathrm{s}$ temperatura da célula: a) $\mathrm{T} 70{ }^{\circ} \mathrm{C}$ e b) $\mathrm{T} 90^{\circ} \mathrm{C}$.



\section{Capítulo IV}

Para ambas temperaturas estudadas $70{ }^{\circ} \mathrm{C}$ e $90{ }^{\circ} \mathrm{C}$, o catalisador $\mathrm{Pt}_{3} \mathrm{Sn}_{1} / \mathrm{C}$ apresentou o inicio da eletrooxidação de etanol a menores potenciais que $\mathrm{Pt}_{9} \mathrm{Sn}_{1} / \mathrm{C}$ e $\mathrm{Pt}_{1} \mathrm{Sn}_{1} / \mathrm{C}$.

Figura 21 Voltametria de varredura linear dos materiais Pt-Sn preparados com 1M de HCOOH, eletrodos com $1 \mathrm{mg}$ de $\mathrm{Pt} \mathrm{cm}{ }^{-2}$ no cátodo e $2 \mathrm{mg} \mathrm{de} \mathrm{Pt} \mathrm{cm}^{-2}$ no ânodo,.célula alimentada com etanol $1 \mathrm{~mol} \mathrm{~L}^{-1}$ a $2 \mathrm{ml} \mathrm{min}^{-1}$ no ânodo e hidrogênio no catodo. $\mathrm{V}=10 \mathrm{mV} / \mathrm{s}$ temperatura da célula $=$ a) $\mathrm{T} 70{ }^{\circ} \mathrm{Ce} \mathrm{b)} \mathrm{T} 90^{\circ} \mathrm{C}$.
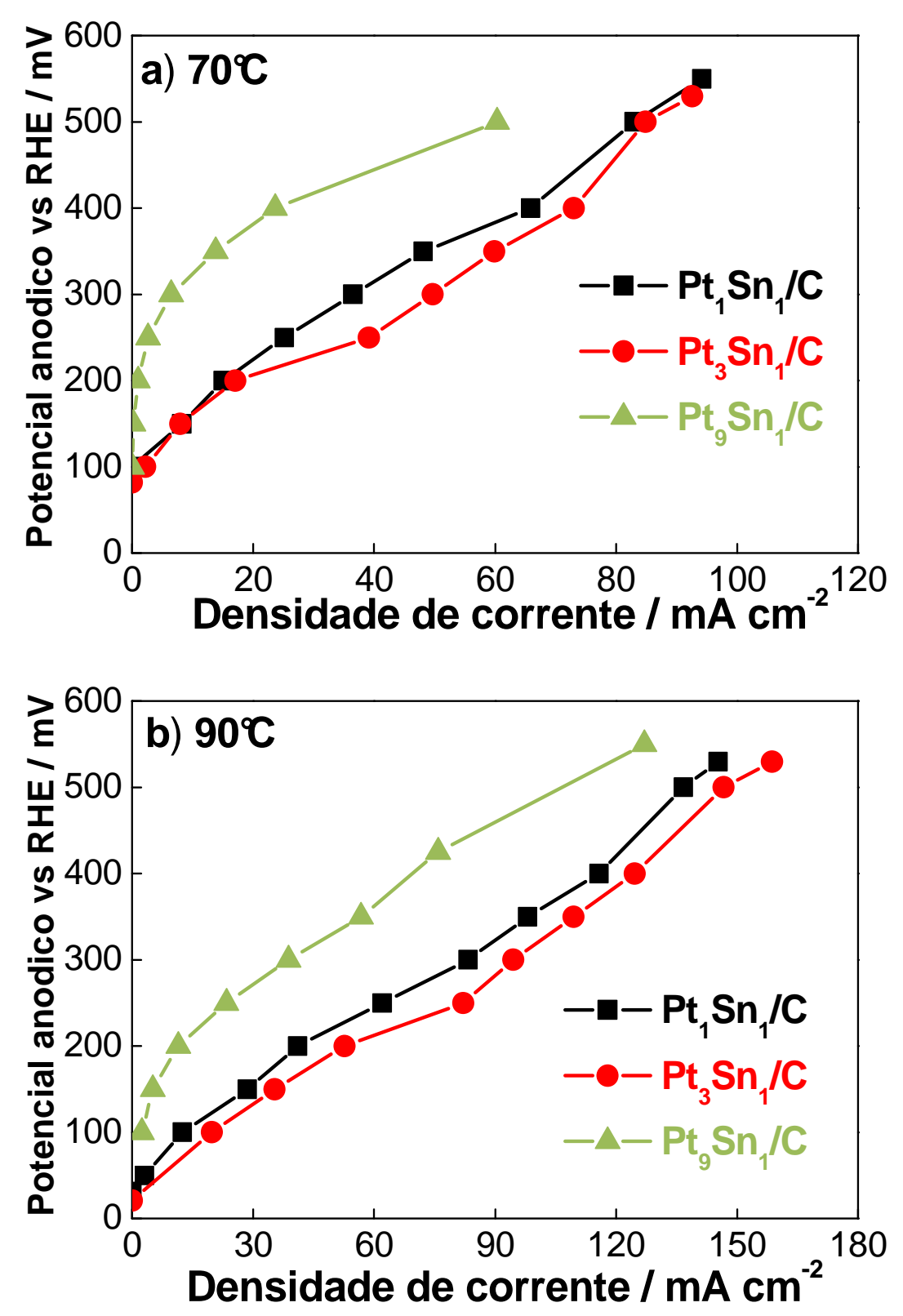

A correlação entre os dados de voltametria linear e de cronoamperometria sugere que, tanto em termos de potencial como de corrente, o eletrocatalisador PtSn/C de composição 3:1 é 


\section{Capítulo IV}

o mais efetivo e ativo na oxidação de etanol. Muitas vezes um catalisador se mostra eficiente para uma reação em um sistema fundamental, mas quando utilizado em um sistema prático o material apresenta um desempenho bastante diferente do esperado. $(77,78)$ Principalmente o material de $\mathrm{Pt}_{3} \mathrm{Sn}$ que se mostra bastante dependente da temperatura de operação.

Figura 22 Voltametria de varredura linear dos materiais Pt-Sn preparados com 2M de HCOOH, eletrodos com $1 \mathrm{mg}$ de $\mathrm{Pt} \mathrm{cm}^{-2}$ no cátodo e $2 \mathrm{mg}$ de $\mathrm{Pt} \mathrm{cm}^{-2}$ no ânodo,.célula alimentada com etanol $1 \mathrm{~mol} \mathrm{~L}^{-1}$ a $2 \mathrm{ml} \mathrm{min}^{-1}$ no ânodo e hidrogênio no cátodo. $\mathrm{V}=10 \mathrm{mV} / \mathrm{s}$ temperatura da célula = a) $\mathrm{T} 70{ }^{\circ} \mathrm{C} \mathrm{e} \mathrm{b)} \mathrm{T} 90{ }^{\circ} \mathrm{C}$.
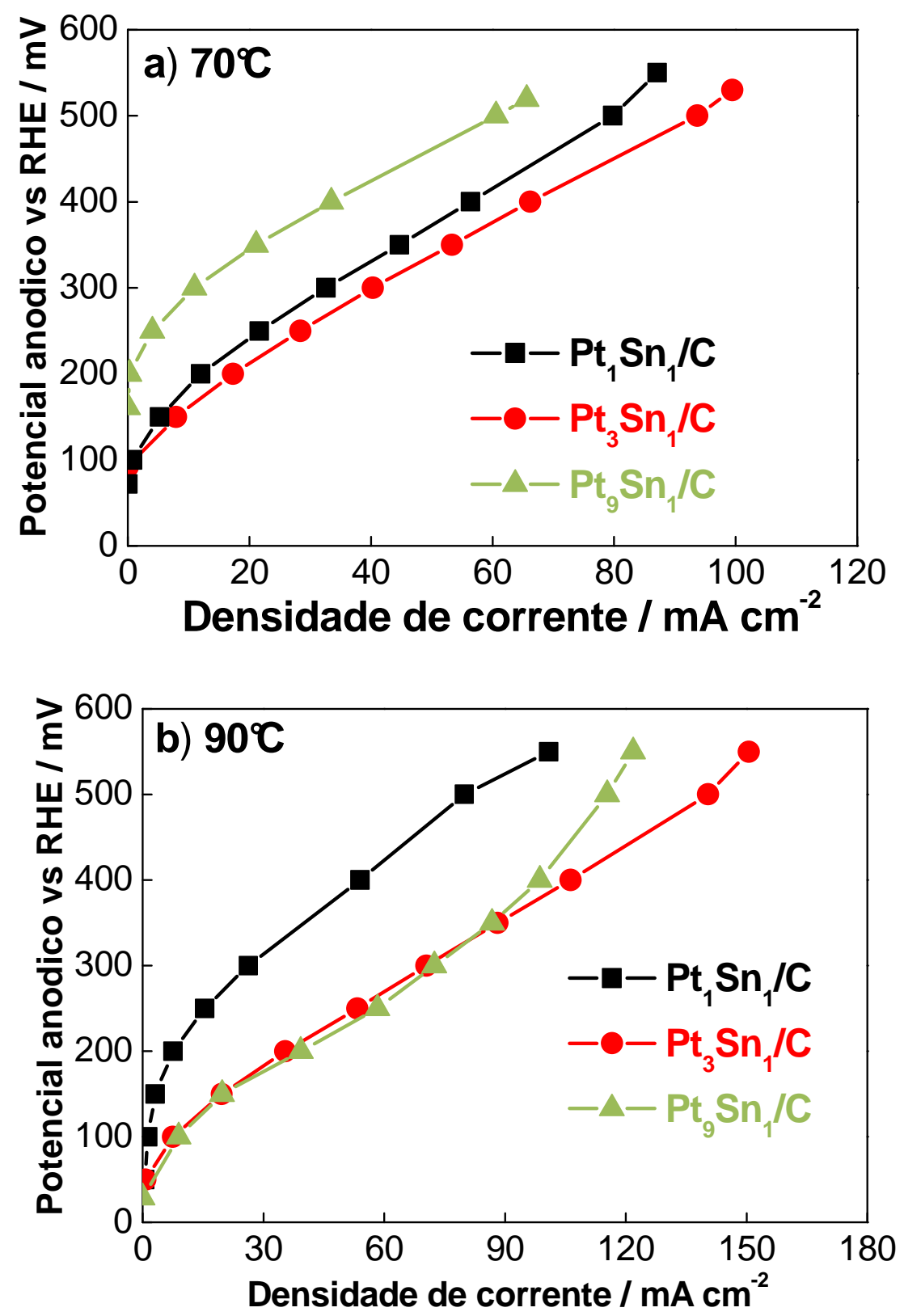

Observando os dados de voltametria linear, verifica-se que há necessidade de um equilíbrio adequado entre Sn e Pt principalmete na superfície, e assim foram analisados por XPS 


\section{$\underline{\text { Capítulo IV }}$}

a quantidade metálica e de óxidos. Estes resultados confirmam que a metodologia é bastante promissora para a preparação dos catalisadores. No entanto, como uma segunda evidência, parece também que as amostras com o maior teor de Sn metálico ou Sn ligado mostram um melhor desempenho especialmente em altas correntes. Provavelmente, o conteúdo elevado de $\mathrm{SnO}_{2}$ ocorre tanto na massa como na região perto da superfície dos catalisadores provocando um aumento de restrições ôhmicas ou modificando a cobertura de resíduos etanólicos. É difícil discriminar entre estes dois efeitos, ou seja, a razão $\mathrm{Pt} / \mathrm{Sn}$ na superfície e o conteúdo de $\mathrm{SnOx}$ ligado ao Sn.

Zhou et al; em um estudo com catalisadores de $\mathrm{PtSn}$ verificaram que o desempenho destes materiais em células unitárias de etanol direto eram diferentes um do outro, trabalhando com diferentes temperaturas. Verificou-se que, o material $\mathrm{Pt}_{3} \mathrm{Sn}_{2} / \mathrm{C}$ apresentou melhor desempenho a $60^{\circ} \mathrm{C}$, enquanto que as células a combustível com etanol direto com o catalisador $\mathrm{Pt}_{2} \mathrm{Sn}_{1} / \mathrm{C}$ e $\mathrm{Pt}_{3} \mathrm{Sn}_{2} / \mathrm{C}$ exibiram desempenhos semelhantes a $75^{\circ} \mathrm{C}$. Além disso, a $90^{\circ} \mathrm{C}$, $\mathrm{Pt}_{2} \mathrm{Sn}_{1} / \mathrm{C}$ foi identificado como um catalisador anódico mais adequado para as células a combustível de etanol direto em termos de densidade máxima de potência. Os autores atribuiram estes resultados os parâmetros de rede e efeitos ôhmicos, que estão relacionados com o conteúdo Sn, sendo desta maneira pensados como os principais fatores que influenciam a atividade do catalisador e, conseqüentemente, o desempenho das células a combustível de etanol direto.(74)

Colmati et al, $(68,74,75)$ observaram que Pt-Sn é mais ativo para a reação de oxidação de etanol tendo início em aproximadamente $100 \mathrm{mV}$ vs. ERH enquanto que outros materias bimetálicos, como por exemplo no caso do Pt Ru a reação tem início apenas em $300 \mathrm{mV}$ vs. ERH a uma temperatura de célula de $90{ }^{\circ} \mathrm{C}$. (76)

A cronoamperometria foi utilizada para estudar o efeito do tempo de operação na atividade eletrocatalítica em eletrodos de trabalho contendo diferentes composições atômicas de metais frente à eletrooxidação de etanol a um determinado potencial constante de $0.4 \mathrm{~V}$. Os resultados encontraram-se nas Figura 23-25. As cronoamperometrias mostram que os eletrocatalisadores avaliados apresentaram-se bastante ativos e estáveis. No potencial analisado, observa-se o destaque em termos de densidade de corrente do material $\mathrm{Pt}_{3} \mathrm{Sn}_{1} / \mathrm{C}$ frente aos outros catalisadores. 
Capítulo IV

Figura 23 Cronoamperometrias a 0,4 V dos materiais Pt-Sn preparados com 0,5M de HCOOH, eletrodos com $1 \mathrm{mg}$ de $\mathrm{Pt} \mathrm{cm}^{-2}$ no cátodo e $2 \mathrm{mg}$ de $\mathrm{Pt} \mathrm{cm}^{-2}$ no ânodo,.célula alimentada com etanol $1 \mathrm{~mol} \mathrm{~L}^{-1}$ a $2 \mathrm{ml} \mathrm{min}{ }^{-1}$ no ânodo e oxigênio no cátodo. temperatura da célula $=$ a) $\mathrm{T} 70^{\circ} \mathrm{C}$ e b) $\mathrm{T} 90^{\circ} \mathrm{C}$.



\section{Capítulo IV}

Figura 24 Cronoamperometrias a 0,4 V dos materiais Pt-Sn preparados com $1 \mathrm{M}$ de $\mathrm{HCOOH}$, eletrodos com $1 \mathrm{mg}$ de $\mathrm{Pt} \mathrm{cm}^{-2}$ no cátodo e $2 \mathrm{mg}$ de $\mathrm{Pt} \mathrm{cm}^{-2}$ no ânodo,.célula alimentada com etanol $1 \mathrm{~mol} \mathrm{~L}^{-1}$ a $2 \mathrm{ml} \mathrm{min}^{-1}$ no ânodo e oxigênio no cátodo. temperatura da célula = a) $\mathrm{T} 70{ }^{\circ} \mathrm{C}$ e b) $\mathrm{T} 90^{\circ} \mathrm{C}$.
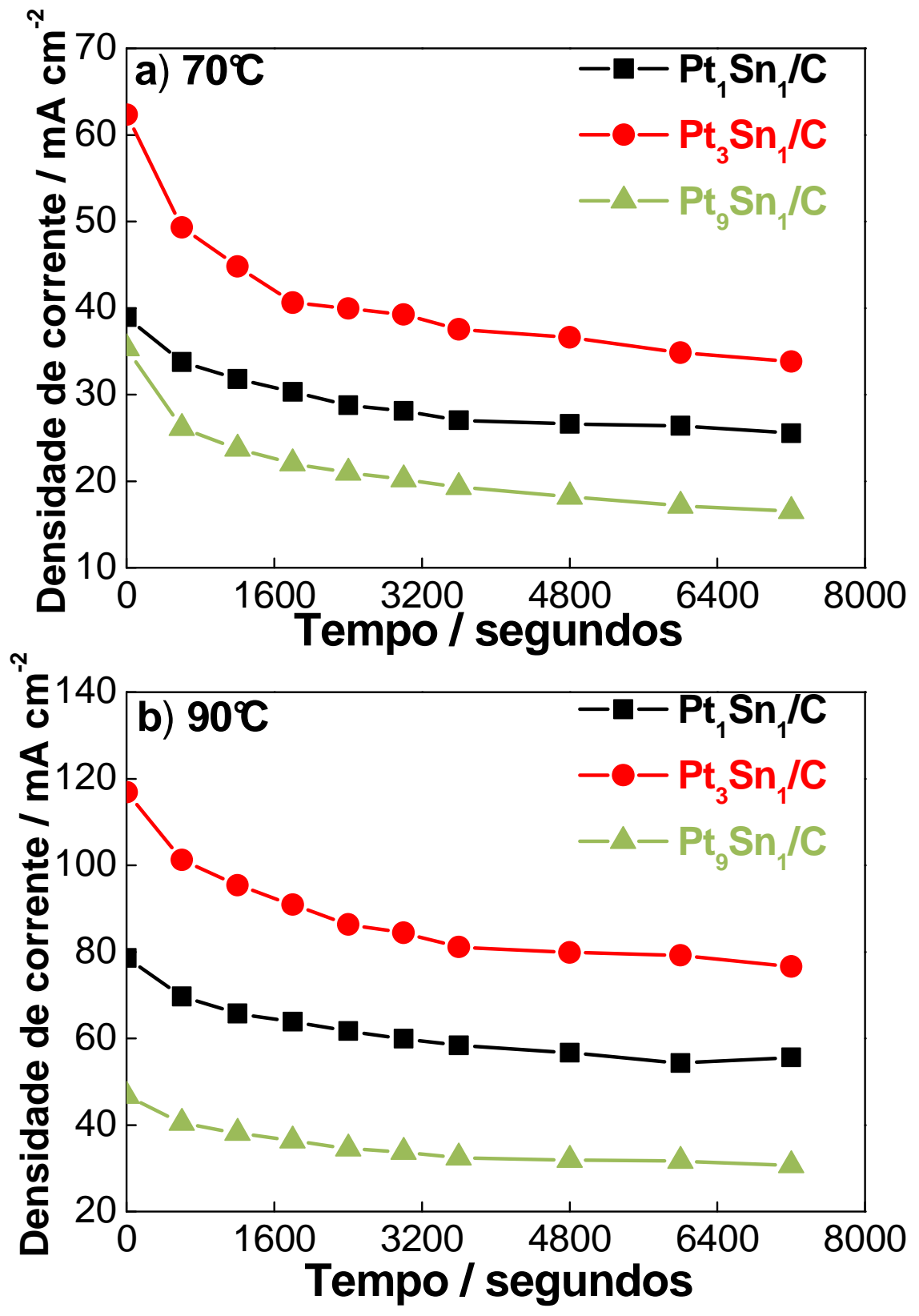

Resultados controversos sobre o efeito do teor de Sn nos catalisadores de Pt-Sn no desempenho da célula foram relatados. Outro fator importante e visualizado por Mayrhofer et al.; (33) e que interfere na atividade dos catalisadores foi visualizada pelas análises de TEM onde o desprendimento de partículas inteiras e a migração estão relacionados uns com os outros, uma 


\section{Capítulo IV}

vez que pode ser vista como uma consequência de um enfraquecimento das interações entre as nanopartículas metálicas e o suporte de carbono.

Figura 25 Cronoamperometrias a 0,4 V dos materiais Pt-Sn preparados com $2 \mathrm{M}$ de HCOOH, eletrodos com $1 \mathrm{mg}$ de $\mathrm{Pt} \mathrm{cm}{ }^{-2}$ no cátodo e $2 \mathrm{mg}$ de $\mathrm{Pt} \mathrm{cm}^{-2}$ no ânodo,.célula alimentada com etanol $1 \mathrm{~mol} \mathrm{~L}^{-1}$ a $2 \mathrm{ml} \mathrm{min}{ }^{-1}$ no ânodo e oxigênio no cátodo. temperatura da célula $=$ a) $\mathrm{T} 70^{\circ} \mathrm{C}$ e b) $\mathrm{T} 90^{\circ} \mathrm{C}$.


Lamy et al. (46) prepararam eletrocatalisadores $\mathrm{Pt}-\mathrm{Sn} / \mathrm{C}$ com relações atómicas Pt: Sn variando de 90:10 a 50:50 e observaram uma composição ótima de estanho na faixa Sn 10-20 \%. 
Capítulo IV

Inversamente, Zhou et al. (48) descobriram que Pt-Sn/C com proporções molares Pt:Sn de 66:33, 60:40 e 50:50 são mais ativos que eletrocatalisadores com razões molares 75:25 e 80:20, com a composição óptima na gama de 33 - 40 \%, dependendo da temperatura de operação da DEFC.

No entanto, a maioria dos resultados na literatura referem-se à concentração em massa. Os nossos resultados mostram que há um efeito primordial das características da superfície na determinação do desempenho de eletrocatalisadores para a oxidação eletroquímica de etanol.

\subsection{Produtos da reação de oxidação de etanol}

Figura 26 Produtos de reação formados durante a operação: a) $70^{\circ} \mathrm{C}$ e b) $90^{\circ} \mathrm{C}$.

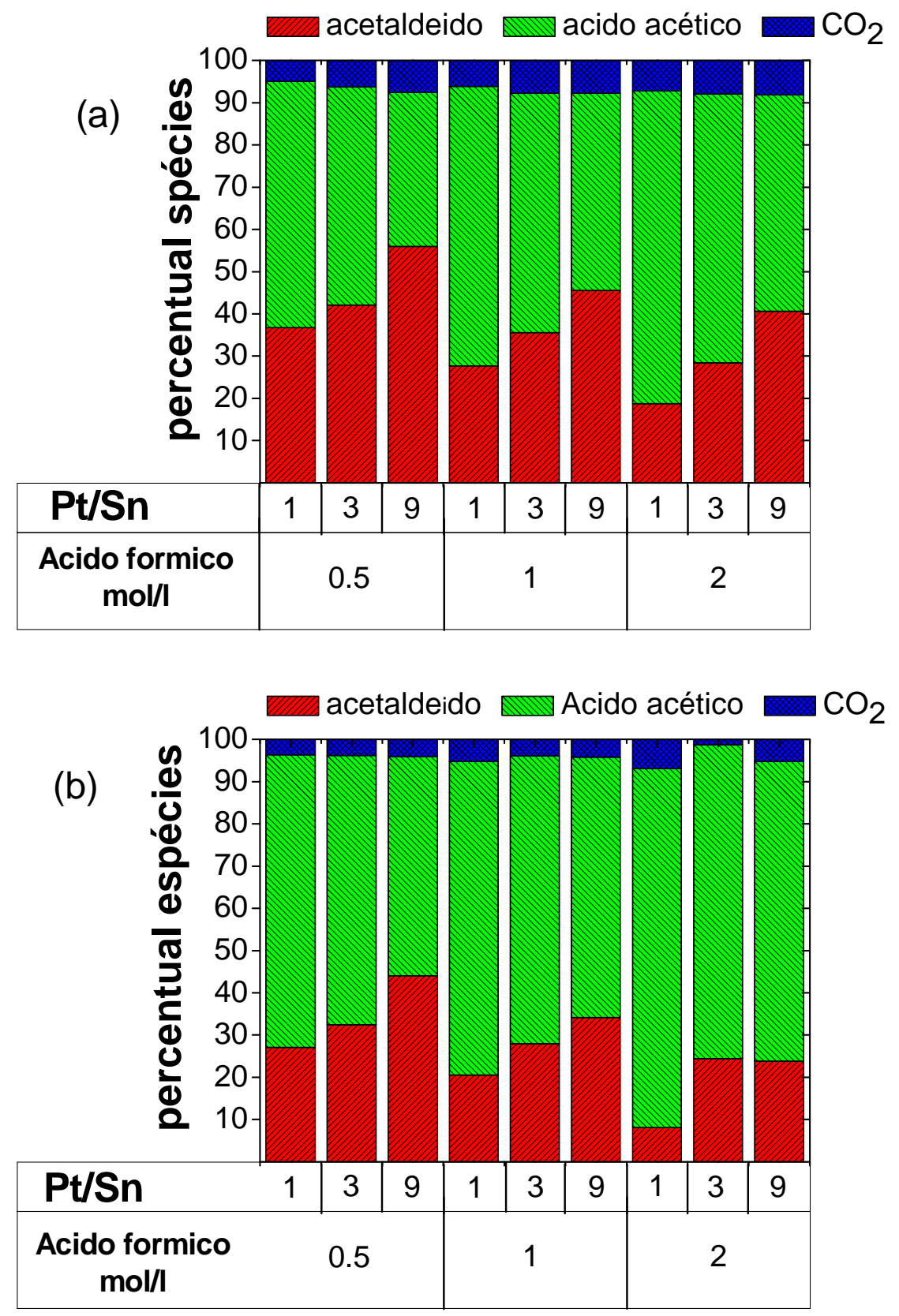




\section{Capítulo IV}

Os resultados relativos aos produtos de reação formados pela operação de eletrocatalisadores diferentes mostram que os produtos de reação principais são ácido acético e acetaldeído, enquanto que um menor teor de $\mathrm{CO}_{2}$ é formado. Ao aumentar a temperatura, como relatado em outros estudos (84-87) o teor de ácido acético aumenta com relação ao acetaldeído, mas infelizmente para estes catalisadores não há aumento significativo do rendimento de $\mathrm{CO}_{2}$ com o aumento da temperatura. Geralmente, o etanol se adsorve em sítios de platina que conduzem a uma espécie $\mathrm{Pt}_{-} \mathrm{CH}_{3}-\mathrm{CO}$, e que o $\mathrm{Sn}$ ativa água em potenciais inferiores produzindo espécies $\mathrm{OH}$ adsorvidas. Mas, um promotor adicional parece ser necessário para o último passo. $\mathrm{Na}$ verdade, a clivagem da ligação C-C é a condição principal para alcançar bons resultados. Assim, os esforços particulares devem ser dirigidos para a formulação de catalisadores que possuam capacidade de promover a cisão de ligações C-C. Para além do controle do tamanho de partícula e da distribuição de tamanho de partícula, de importância fundamental são a optimização da composição da superfície, o grau de formação da liga e o teor de óxido de nos catalisadores. Por conseguinte, é necessário escolher o método de preparação para se obter as características desejadas de morfologia, propriedades físicas, e características de superfície.

Os produtos de reação formados durante a operação com diferentes eletrocatalisadores são mostrados na figura 26 e consistem principalmente em ácido acético e acetaldeído, enquanto que um menor percentual de $\mathrm{CO}_{2}$ foi formado.

Aumentando a temperatura, o percentual de ácido acético vs acetaldeído aumentou, mas infelizmente para estes catalisadores não houve aumento significativo do rendimento de $\mathrm{CO}_{2} \mathrm{com}$ a temperatura. No entanto, comparando os resultados obtidos para as diferentes formulações de catalisadores, é evidente que a seletividade para o aumento de ácido acético aumentou com o teor de Sn no catalisador e diminui com a diminuição da concentração do agente redutor utilizado na preparação de catalisadores. Assim, a melhor composição nominal, em termos de desempenho é o $\mathrm{Pt}_{3} \mathrm{Sn}_{1}$ obtido na presença de uma baixa concentração $(0,5 \mathrm{M})$ de agente redutor. Pode-se observar na Figura 26 que tanto a composição $\mathrm{Pt}_{1} \mathrm{Sn}_{1}$ nominal e uma grande concentração de agente redutor $(2 \mathrm{M})$ proporcionaram o rendimento mais elevado de ácido acético e acetaldeído em vez de $\mathrm{CO}_{2}$. 
Capítulo IV

\section{PARTE II - ESTUDO DE ESTABILIDADE}

\subsection{Estudos em camada ultrafina}

Voltametria cíclica em eletrólito suporte: Os voltamogramas cíclicos dos eletrocatalisadores $\mathrm{Pt} / \mathrm{C}$ e $\mathrm{Pt}_{3} \mathrm{Sn} / \mathrm{C}$ em meio ácido e na ausência de etanol são apresentados na figura 28. O perfil de corrente-potencial da interface eletrodo-solução em meio ácido é de grande importância em eletrocatálise, uma vez que fornece importantes informações a respeito da superfície do metal em contato com a solução.

Figura 27 Voltamogramas cíclicos dos eletrocatalisadores $\mathrm{Pt} / \mathrm{C}$ e $\mathrm{Pt}_{3} \mathrm{Sn} / \mathrm{C}$ em solução de 0,5 mol $\mathrm{L}^{-1}$ de $\mathrm{H}_{2} \mathrm{SO}_{4}$.

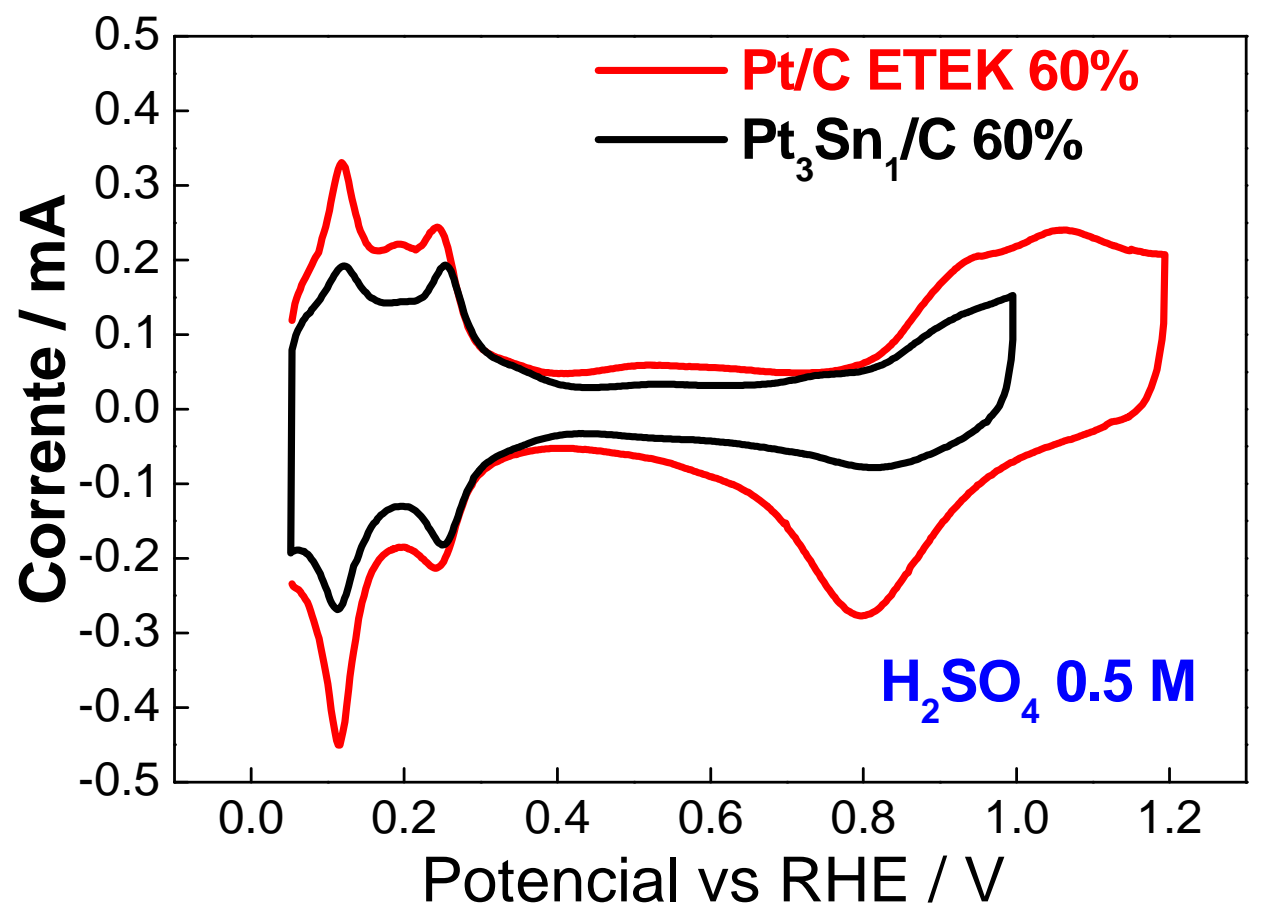

O voltamograma cíclico do eletrocatalisador de $\mathrm{PtSn}$ não apresenta uma região de adsorção de hidrogênio que é formado pela redução dos íons $\mathrm{H}^{+}$presentes na solução (varredura catódica) e de dessorção de hidrogênio (varredura anódica) entre $(0,05$ a 0,4 V) bem definida em comparação com o eletrocatalisador de Pt. Este processo é reversível, uma vez que as cargas envolvidas em ambos os processos são idênticas e não se observam deslocamentos entre os máximos dos picos de adsorção e oxidação de hidrogênio nas varreduras catódica e 


\section{Capítulo IV}

respectivamente, com o aumento da velocidade de varredura. O eletrocatalisador PtSn mostrou uma região de adsorção/dessorção reduzida, este efeito pode estar relacionado com a presença de Sn recobrindo os sítios de platina, devido provavelmente a que a redução da platina ocorre a uma velocidade maior do que a do estanho.

Cronoamperometrias: Os experimentos de cronoamperometria foram realizados para avaliar o comportamento dos eletrocatalisadores ao longo do tempo (figura 29). Os resultados foram obtidos em $0,5 \mathrm{~mol} \mathrm{~L}^{-1}$ de $\mathrm{H}_{2} \mathrm{SO}_{4}$ e $1 \mathrm{~mol} \mathrm{~L}^{-1}$ de etanol em potencial de $0,5 \mathrm{~V}$ versus ERH considerando 3600 segundos. Este potencial é escolhido por estar contido na faixa de interesse tecnológico das células a combustível de etanol direto $(0,3-0,6 \mathrm{~V})$.

Figura 28 Curvas amperométricas em $1 \mathrm{~mol} \mathrm{~L}^{-1}$ de etanol em solução de 0,5 mol L ${ }^{-1}$ de $\mathrm{H}_{2} \mathrm{SO}_{4}$ para os eletrocalisadores de $\mathrm{Pt} / \mathrm{C}$ e $\mathrm{Pt}_{3} \mathrm{Sn} / \mathrm{C}$.

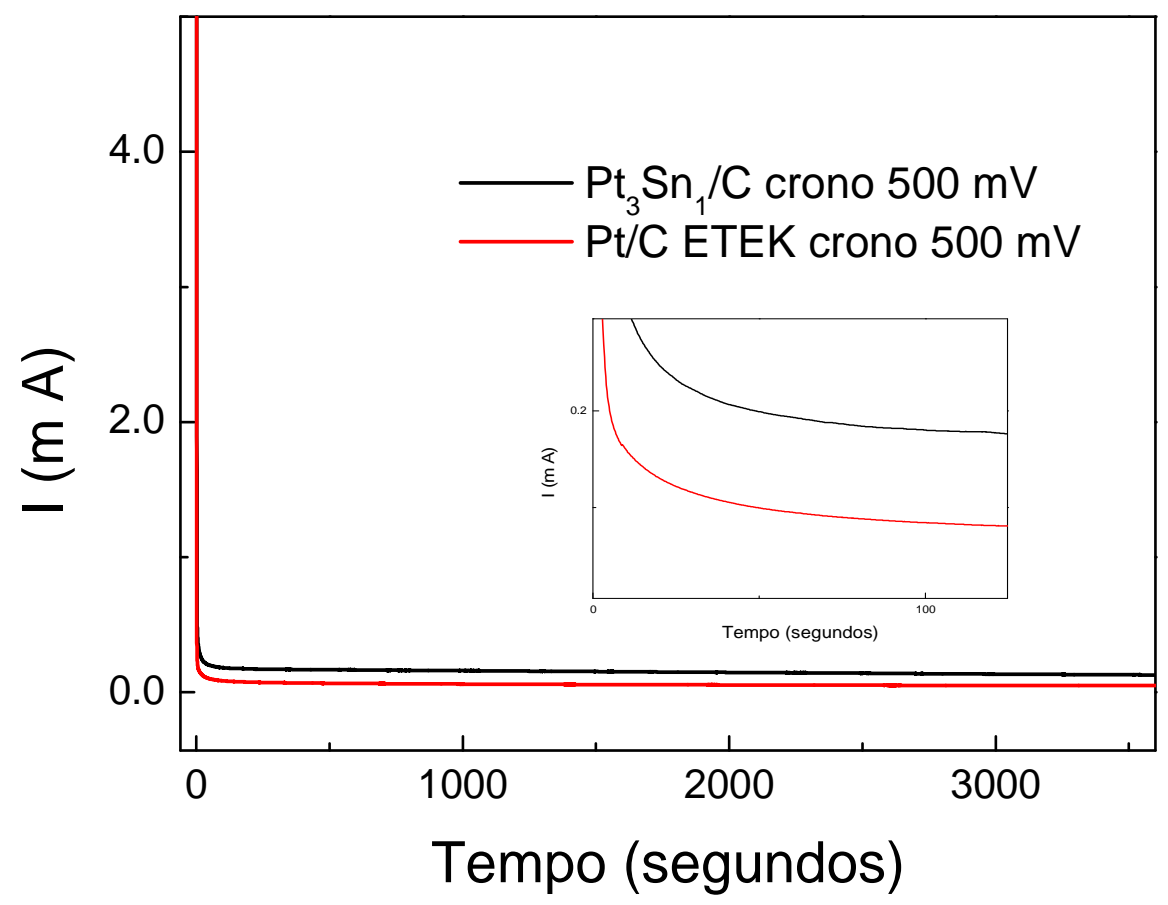

Nas curvas cronoamperométricas há uma acentuada queda de corrente inicial nos primeiros 2 minutos, posteriormente os valores de corrente praticamente permaneceram constantes até o final das análises. As cronoamperometrias sugerem que os eletrocatalisadores avaliados apresentam-se bastante ativos e estáveis. Observa-se que o eletrocatalisador de PtSn apresenta valores de corrente de oxidação de etanol ligeiramente superior à corrente gerada pelo eletrocatalisador comercial E-TEK. 


\section{Capítulo IV}

Stripping de CO: O stripping de CO para o catalisador de Pt, apresentado na figura 29, mostra a região entre 0,05 e $0,7 \mathrm{~V}$ a ausência de picos referentes à dessorção de hidrogênio, definindo-se somente correntes de carregamento da dupla camada. Este fato evidencia que a adsorção de CO foi efetiva, bloqueando completamente so sítios de Pt. Também pode-se observar que se define um pico entre 0,8 e $0,9 \mathrm{~V}$, este pico é mais estreito que o pico encontrado para o catalisador de PtSn, provavelmente pode estar relacionado com o menor tamanho de partícula e ausência de aglomeração observados por TEM. Camara et al (88) propõem que o stripping de $\mathrm{CO}$ pode ter relação bem próxima com a distribuição do tamanho de partículas, onde a oxidação de $\mathrm{CO}$ sobre partículas menores ocorre em maiores potenciais e vice e versa. $\mathrm{O}$ catalisador de $\mathrm{Pt} / \mathrm{C}$, obteve uma área ativa de $8,87 \mathrm{~cm}^{2}$.

Figura 29 (-) Stripping de $\mathrm{CO}$ em meio de $\mathrm{H}_{2} \mathrm{SO}_{4} 1 \mathrm{M}$ para os eletrocalisadores de $\mathrm{Pt} / \mathrm{C}$. (一) Voltamograma subsequente ao stripping de CO.

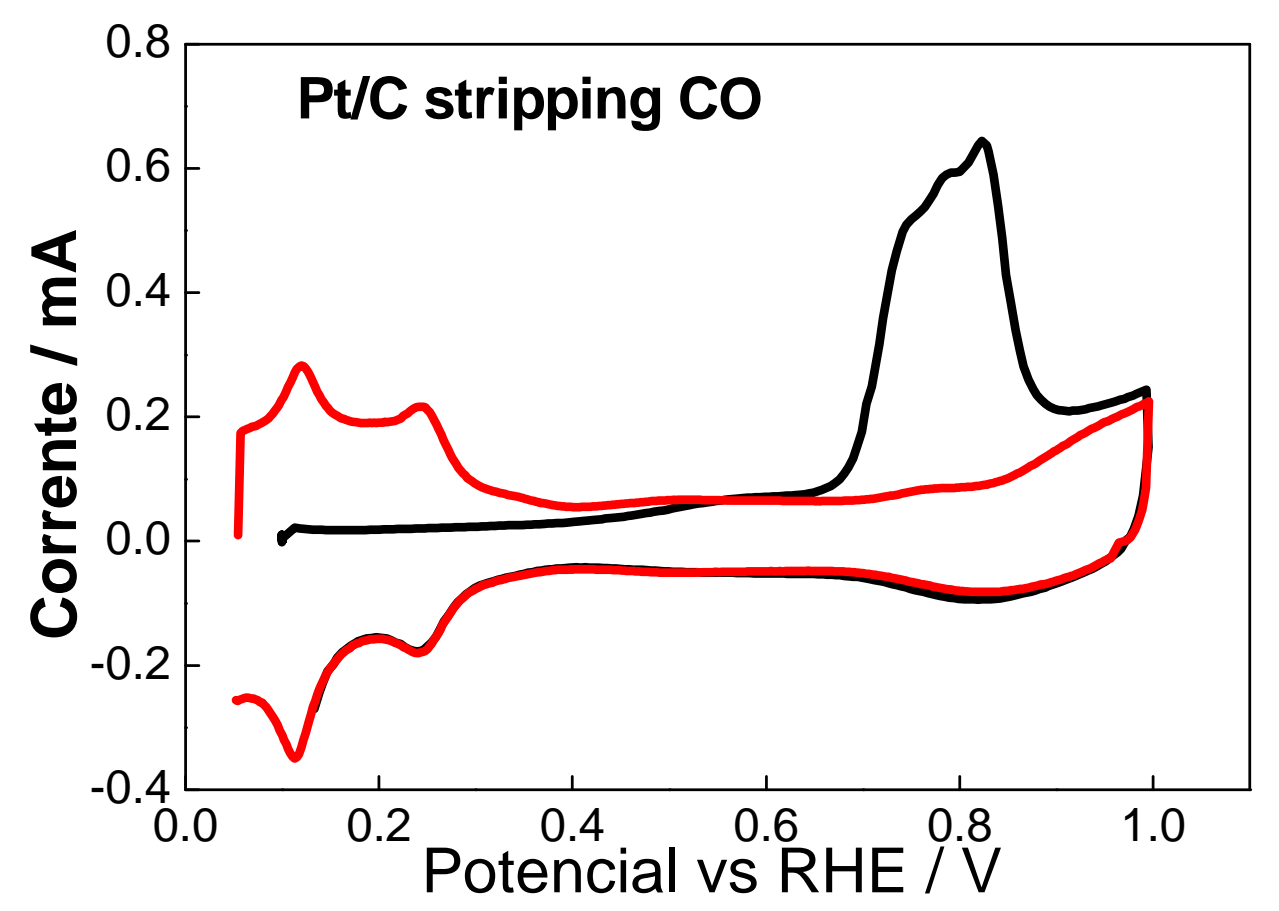

A determinação da área ativa dos eletrocatalisadores suportados é de extrema importância tanto do ponto de vista dos estudos fundamentais, quanto aplicados. No primeiro caso, a determinação da área ativa permite a comparação dos resultados obrtidos para um dado material com os experimentos realiados em dias distintos ou ainda a comparação entre os resultados obtidos com outros materiais ou por autores diferentes. Em termos aplicados, a determinação da área permite se conhecer, por exemplo, os materiais que possuem a maior área ativa por unidade de massa. 


\section{Capítulo IV}

O Voltamograma de stripping de $\mathrm{CO}$ obtido para $\mathrm{Pt}_{3} \mathrm{Sn} / \mathrm{C}$ é mostrado na figura 30, onde é visto que além do ombro em $0,43 \mathrm{~V}$ há a formação de um pico principal e um secundário em 0,7 e 0,8 V. Se comparado com o material $\mathrm{Pt} / \mathrm{C}$, os processos relacionados ao stripping de CO ou seja o deslocamento do início da oxidação de CO, aparecem em menores sobrepotenciais, indicando um efeito de formação de espécies oxigenadas em potenciais menos positivos do que $\mathrm{Pt} / \mathrm{C}$ em sítios de $\mathrm{SnO}_{2}$. Para $\mathrm{Pt}_{3} \mathrm{Sn} / \mathrm{C}$, obteve-se uma área ativa de $7,78 \mathrm{~cm}^{2}$.

Figura 30 (-) Stripping de $\mathrm{CO}$ em meio de $\mathrm{H}_{2} \mathrm{SO}_{4} 1 \mathrm{M}$ para os eletrocalisadores de $\mathrm{Pt}_{3} \mathrm{Sn} / \mathrm{C}$. (一) Voltamograma subsequente ao stripping de CO.

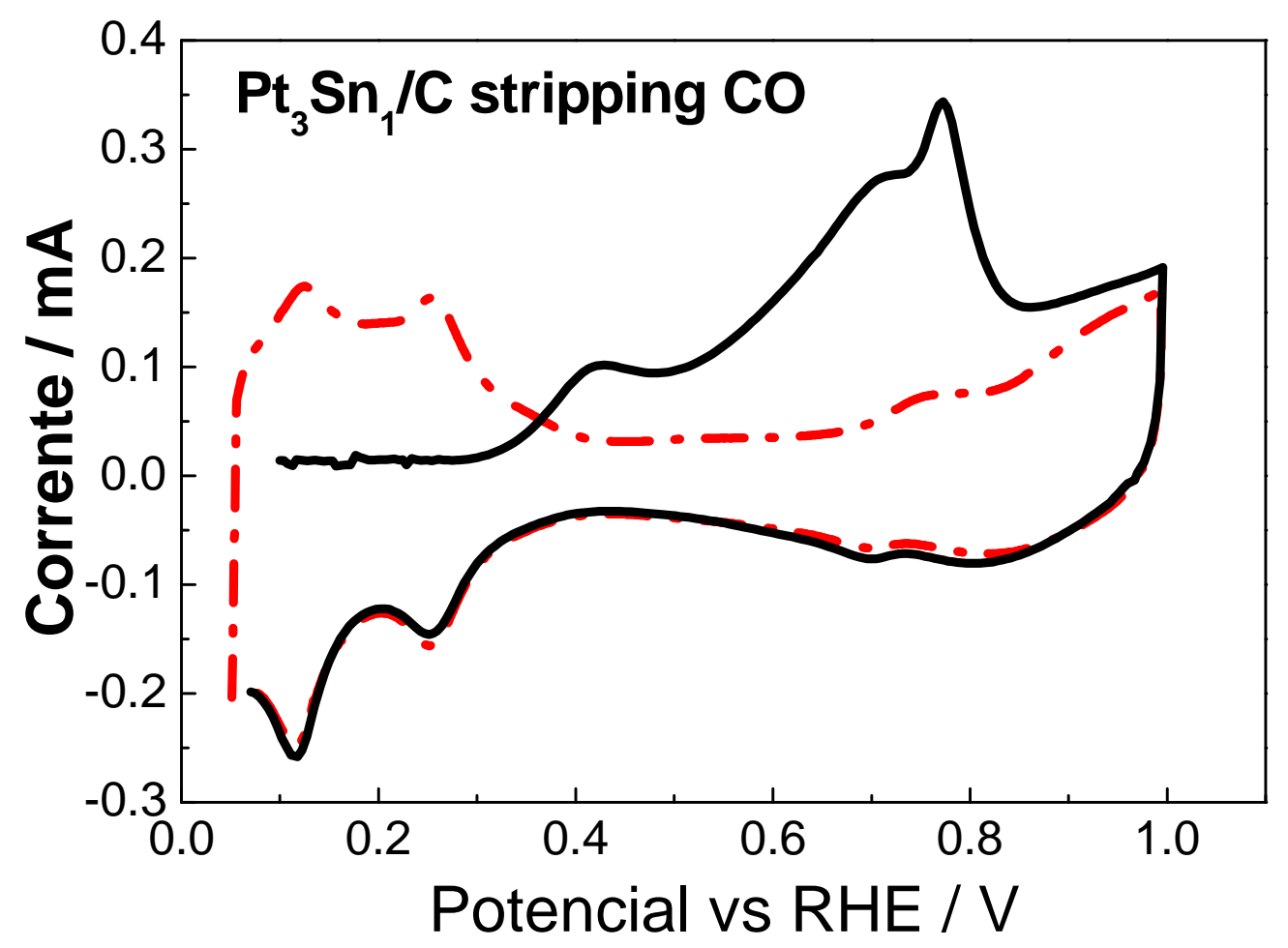

\subsubsection{Estabilidade de um sistema DEFC com base no catalisador $\mathrm{Pt}_{3} \mathrm{Sn}_{1} / \mathrm{C}$}

Com base no estudo feito sobre a eletrooxidação de etanol, decidiu-se fazer um estudo preliminar de estabilidade. Este se realizou levando em consideração os processos "ligado" e “desconexão" da célula, visando as aplicações portáteis mais apropriadas para um sistema desta natureza. Propôs-se um estudo de estabilidade intermitente, no qual foram utilizadas diferentes estratégias de "liga-desliga" do sistema. Durante o estudo, diferentes análises com o intuito de caracterizar o sistema foram consideradas: 1) Curvas de polarização e de impedância durante a 
Capítulo IV

operação da célula, com objetivo de monitorar alguns parâmetros eletroquímicos de interesse: rendimento em termos de densidade de corrente e de potência do sistema. 2) Caracterização estrutural e morfológica do catalisador mediante medidas de difração de raios $\mathrm{X}$ e de microscopia eletrônica de transmissão.

\subsubsection{Estratégia de estudo dos testes de estabilidade}

A estratégia para a realização do ensaio de estabilidade foi a seguinte: operando o sistema a uma temperatura de $90{ }^{\circ} \mathrm{C}$, com oxigênio no cátodo pressurizado a 2 bar relativos, e com uma concentração de etanol $1 \mathrm{M}$, seguiu-se o seguinte protocolo operacional:

a) Primeira parte do ensaio de estabilidade. Antes do início dos testes, o catalisador foi caracterizado por DRX, TEM, voltametria cíclica, e se realizaram curvas de polarização e de impedância. As medidas eletroquímicas foram realizadas nas condições de operação da célula, sendo no último caso o potencial fixado em $0,4 \mathrm{~V}$. Igualmente, realizou-se uma varredura cíclica de potencial entre 0,05 e $0,7 \mathrm{~V}$. Concluída esta pré-caracterização, o sistema foi polarizado a 0,4 V durante 50 horas.

b) Segunda etapa dos testes, transcorridas 50 horas, o sistema foi deixado em circuito aberto, parando-se apassagem de combustível, até esfriamento a temperatura ambiente. Concluído isto, o sistema foi deixado em repouso durante 48 horas, e retomou-se seguindo a estratégia detalhada no item a, com a exceção das medidas de caracterização estrutural. O sistema foi polarizado a $0,4 \mathrm{~V}$ durante 100 horas.

c) Terceira etapa, após 100 horas, o sistema foi desconectado seguindo uma estratégia diferente, consistente em polarizar a 0,2 V, substituindo o combustível etanol por água, e esfriando o sistema até temperatura ambiente, momento no qual é desligado completamente. $\mathrm{O}$ sistema foi deixado novamente por 48 horas em repouso, retomando-se a estratégia descrita no item anterior, polarizando ao sistema durante 50 horas a $0,4 \mathrm{~V}$.

d) Quarta etapa, 50 horas polarizado, totalizando 200 horas, o sistema foi desligado da mesma forma que no item $b$, com a exceção da contínua recirculação do etanol até o esfriamento da célula. O sistema foi novamente deixado em repouso durante 48 horas, após as quais foi realizada a correspondente caracterização eletroquímica, tal como descrito no item c. $\mathrm{O}$ sistema foi novamente polarizado a $0,4 \mathrm{~V}$ por 50 horas.

e) Quinta etapa do ensaio de estabilidade, finalizadas essas 50 horas, somando 250 horas no total, foram realizadas caracterizações eletroquímica, morfológica e estrutural. 


\section{Capítulo IV}

Seguindo este protocolo, pode-se observar na figura 31 o teste de estabilidade a potencial constante de $0.4 \mathrm{~V}$ por $250 \mathrm{~h}$. Como uma primeira evidência, ocorre uma perda de corrente nas primeiras 5 horas de operação, que provavelmente ocorre pela forte adsorção de intermediários, a corrente aumenta ligeiramente durante as horas restantes. Os possíveis motivos dessa melhora não são muito claros, porém, poderia corresponder a uma ativação do catalisador junto com uma melhor hidratação do eletrólito $\mathrm{Nafion}^{\circledR}$, além de uma possível limpeza da superfície pela oxidação das espécies adsorvidas anteriormente citadas.

Figura 31 Teste de estabilidade de $250 \mathrm{~h}$ em 0,4 V, que inclui três ciclos ligado-desconexão intermediários a 50, 155 e 200 h do catalisador de PtSn/C.

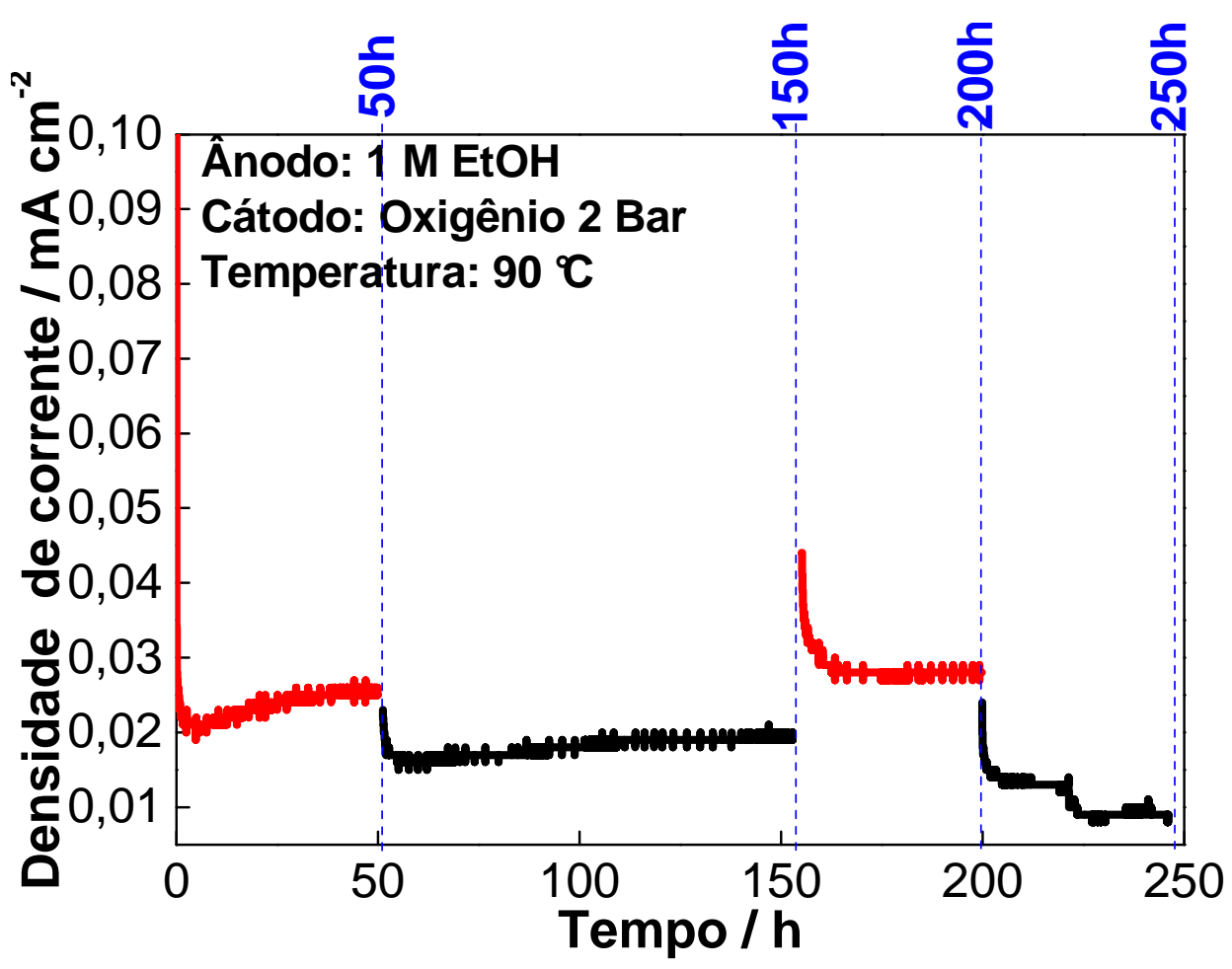

O segundo ciclo após 50 horas de operação mostra um comportamento semelhante, sendo que o desempenho inicial é inferior. Aparentemente o desligamento sob condições de circuito aberto não foi positivo, observando-se um rendimento inferior do sistema durante a seguintes 100 horas. A curva de estabilidade seguiu o mesmo padrão que o mostrado anteriormente. Durante esse procedimento de desconexão do sistema, é provável que os resíduos adsorvidos sobre a superfície do catalisador fiquem ainda retidos, o que poderia justificar essa queda na densidade de corrente quando o sistema foi polarizado. Entretanto, transcorridas 100 horas de operação, o sistema foi desligado bombeando água no ânodo, polarizado a uma 


\section{Capítulo IV}

voltagem de célula de $0,2 \mathrm{~V}$. $\mathrm{Na}$ ausência de combustível, a corrente decresceu até praticamente atingir um valor de zero. Embora a voltagem permanecesse fixada, os potenciais de cada um dos eletrodos variam, seguindo uma progressão que poderia se ajustar à curva da Figura 33.

Figura 32 Esquema representativo da variação dos potenciais do ânodo e do cátodo durante o período de desconexão da célula



É de se esperar a queda na densidade de corrente perante a ausência de combustível. Isto vem acompanhado de um incremento nos sobrepotenciais do ânodo e do cátodo, mantendo constante a diferença de potencial de $0,2 \mathrm{~V}$. O incremento no potencial do ânodo deve favorecer a oxidação dos intermediários de reação, limpando a superfície da platina. De fato, o teste de estabilidade nas horas seguintes mostrou uma melhora significativa no rendimento, provavelmente devido à maior disponibilidade de centros ativos na superfície do catalisador. Da mesma forma que nos casos anteriores, a célula mostrou uma queda inicial no rendimento, acompanhado de uma melhora progressiva até o fim desta etapa.

Em uma etapa seguinte, a desconexão da célula em circuito aberto e recirculação do etanol mostrou efeitos prejudiciais sobre o rendimento da célula, com a perda irreversível no rendimento. Porém, nos instantes iniciais, é possível observar como decai o rendimento ficando ao mesmo nível que na segunda etapa o teste de estabilidade. A queda final no rendimento, embora não existem razões claras para justificar este comportamento, poderia ser devida a uma degradação irreversível do eletrólito. 
Capítulo IV

Portanto, seria aconselhável durante o uso prolongado de um sistema DEFC, no processo de desconexão, realizar um processo de "limpeza" da superfície do ânodo mediante a polarização do sistema a baixas voltagens substituindo etanol por um componente inerte, tal como a água, eliminando qualquer resíduo de acetaldeído ou ácido acético. Por outro lado, o sistema, para tempos curtos de operação a voltagem constante, mostrou um comportamento que poderia ser considerado como razoavelmente bom, sem degradação além da queda inicial sempre presente devido ao envenenamento do catalisador e aos efeitos do cruzamento.

As curvas de polarização registradas antes do teste de resistência e em intervalos de tempo diferentes, especialmente após o desligamento de vários procedimentos são mostradas na figura 33. O perfil da curva de polarização mostra uma aumento dramático do controle de ativação especialmente no final do teste e após os procedimentos de desligamento em circuito aberto.

Como pode ser observado na figura 33, as curvas de polarização mostram um comportamento similar ao observado durante os experimentos de estabilidade. Inicialmente, o sistema apresenta o melhor rendimento, devido a que o catalisador se encontra sem envenenamento e sem resíduos procedentes da oxidação do etanol. Após a operação durante 50 horas, e o processo de desconexão a circuito aberto, observou-se uma considerável queda no rendimento em termos de corrente, pois é de esperar que a superfície catalítica se encontre significativamente contaminada com os resíduos etanólicos.

Figura 33 Curvas de polarização a intervalos diferentes do ensaio de estabilidade

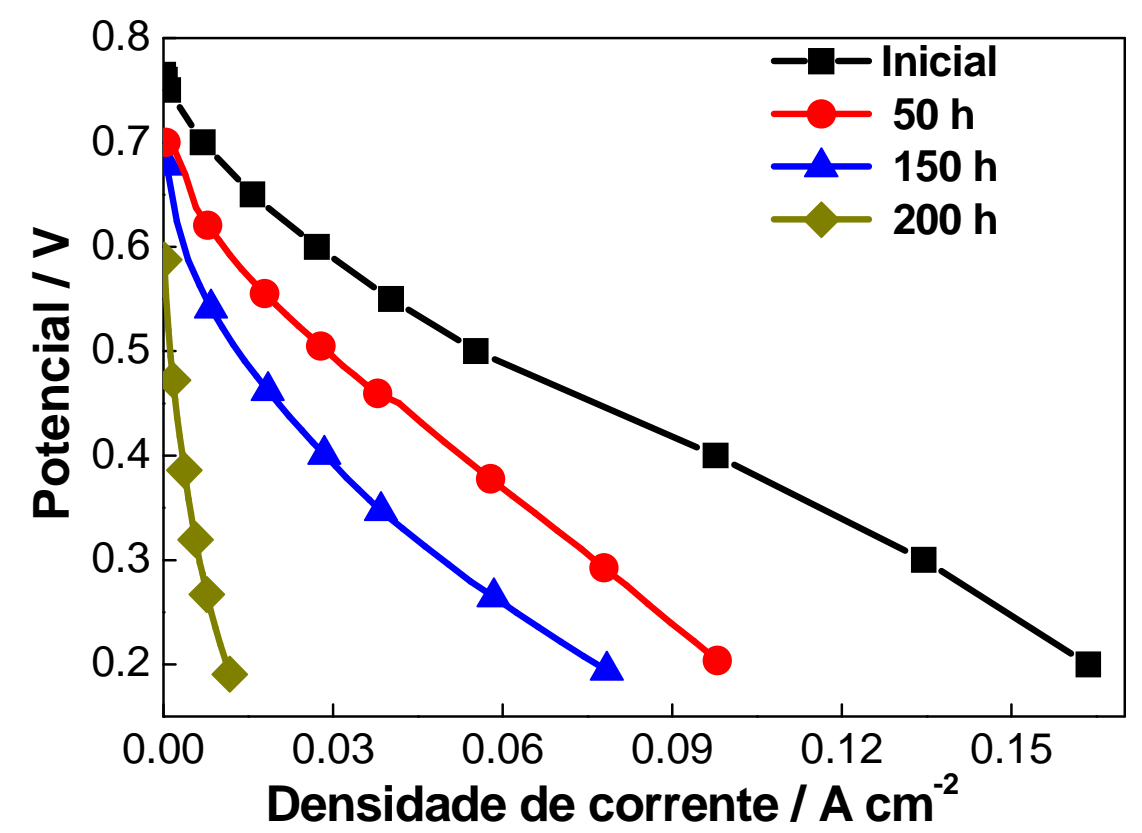




\section{Capítulo IV}

A corroboração deste fato é a melhora depois do processo de desconexão com o sistema polarizado, ajudando à limpeza da superfície do catalisador, e finalmente, o rendimento mais fraco é obtido após o ensaio completo de estabilidade, onde existe uma notável degradação do sistema.

A técnica de impedância eletroquímica é uma poderosa ferramenta que pode fornecer uma quantidade de informações que ajudam no entendimento dos processos superficiais e interfaciais responsáveis pela polarização que ocorre na célula a combustível, tais como aos efeitos resistivos e difusivos que causam redução acentuada no seu desempenho.(89-92)

Espectros de impedância in-situ a diferentes inervalos de tempo e com um intervalo de frequência de $100 \mathrm{kHz}$ a $0.1 \mathrm{~Hz}$ foram registrados. A resistência em série foi determinada a partir da intercepção de alta frequência sobre o eixo real no diagrama de Nyquist. A resistência de transferência de carga foi feita como sendo a diferença entre a baixa frequência de intercepção extrapolada e a intercepção de alta frequência sobre o eixo real. $\mathrm{Na}$ figura 34 pode-se ver a resistência global do sistema, que se mostra menor nos instantes iniciais, aumentando após a operação durante as primeiras 50 horas, e decrescendo após o processo de limpeza da superfície do catalisador. Após 150h observa-se a degradação do sistema. Estes processos indicam que a perda do desempenho durante os vários ciclos não foi devido a degradação da membrana uma vez que a resistência em série é constante e suficientemente baixa $\left(<0,2 \mathrm{ohm} \mathrm{cm}^{2}\right)$. Além disso, uma pequena resposta a alta frequência é designada ao processo catódico que não é significativamente afetado e que, a resposta a baixa frequência atribuída ao ânodo significa que é fortemente afetado demonstrando um aumento da impedância global especialmente após $150 \mathrm{~h}$ e $200 \mathrm{~h}$ de acordo com o decaimento da densidade de corrente do teste de resistência.

Figura 34 Espectros de impedância a intervalos diferentes do ensaio de estabilidade

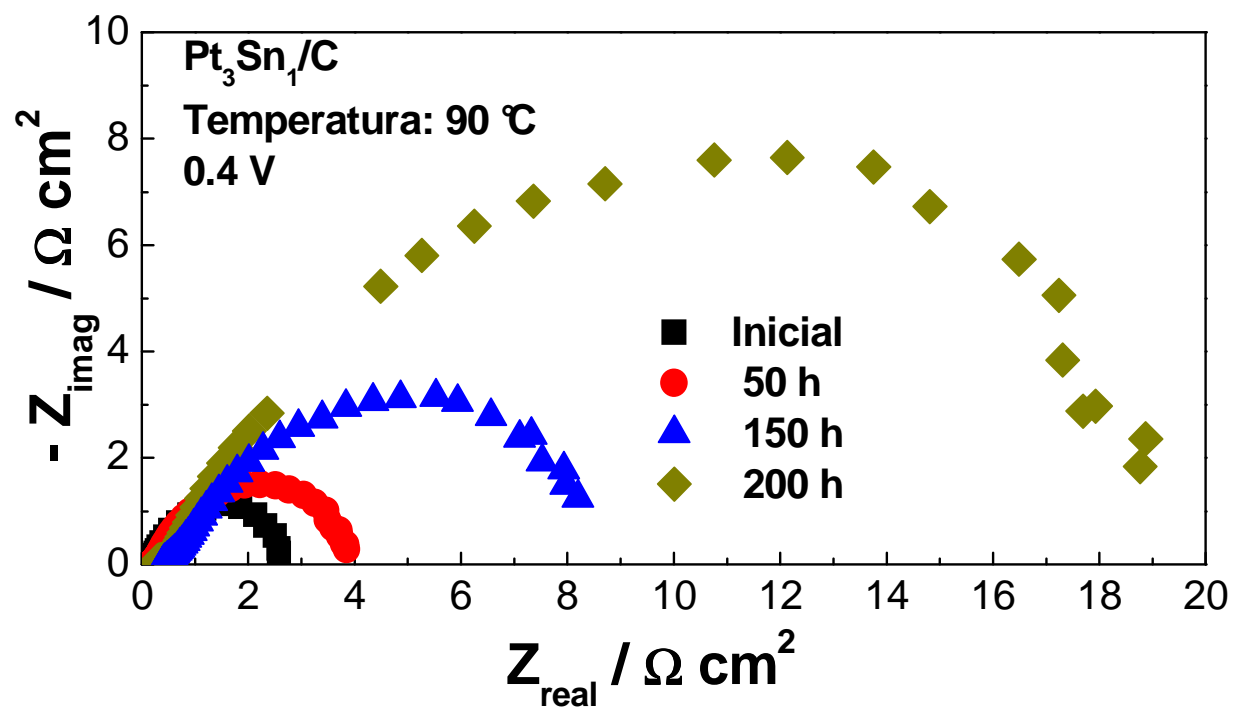




\section{Capítulo IV}

Combinando-se os resultados de EIS antes e após os teste com as análises de microscopia e difração de raios -x, confirma-se que os problemas que ocorrem na camada catalisadora anódica conforme o aumento a resistência de transferência de carga é o principal responsável pela queda de desempenho que ocorre na célula a durante o procedimento intermitente. Estes resultados confirmam a importância do estudo deste processo de ligado/desconexão de um sistema de células a combustível de etanol direto operando de forma intermitente durante um determinado período de tempo. Qualquer processo que favoreça a limpeza da superfície do catalisador ajudará a melhorar o rendimento e a estabilidade do sistema.

Completada a caracterização eletroquímica, é de interesse observar também as mudanças nas características estruturais e morfológicas do catalisador associadas ao processo de estabilidade. Na Figura 35 observam-se os correspondentes difratogramas do catalisador no ânodo e no cátodo.

Figura 35 Difratogramas dos catalisadores utilisados antes e após o teste de estabilidade: (a) no ânodo, (b) no cátodo
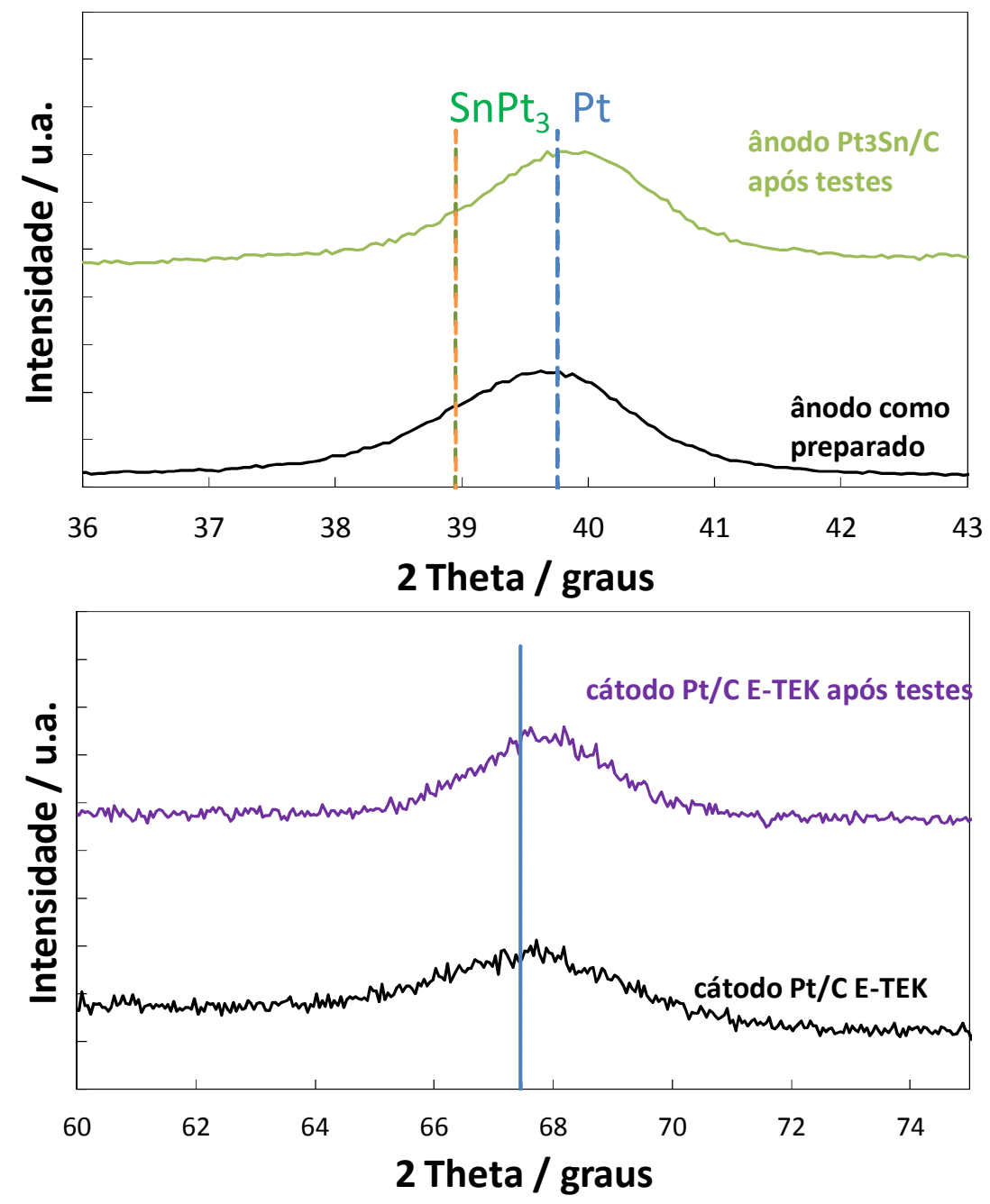


\section{Capítulo IV}

$\mathrm{Na}$ tabela 4, os valores correspondentes ao parâmetro de rede e tamanho do cristalito após testes, podem ser verificados. Observa-se que apenas no caso do último parâmetro, existe mudança, conferindo a estabilidade do catalisador em termos da estabilidade do cristalito. Porém, no caso do parâmetro de rede, para o catalisador do ânodo, existe um deslocamento para maiores valores de 2 Theta, mais próximos ao valor correspondente da platina. Isto poderia indicar que durante o ensaio de durabilidade, perde-se parte da liga $\mathrm{Pt}_{3} \mathrm{Sn} / \mathrm{C}$. O estanho, metal menos nobre que a platina poderia se dissolver, (93) saindo da liga, e, portanto, levando a essa diminuição no parâmetro de rede, especialmente na operação a sobrepotenciais elevados. Eeste processo foi também discutido em outros estudos $(34,94-96)$. Nos processos de parada do sistema o estanho pode se redepositar sobre os cristais já existentes, aumentando o tamanho do cristalito. Este aspecto é crítico, pois pode afetar a capacidade de remoção de espécies de envenenamento adsorvidas no ânodo que aparecem para determinar o passo determinante da cinética de todo o processo. No caso do cátodo, existe um incremento no tamanho do cristalito.

Tabela 4. Tamanho do cristalito e parâmetro de rede dos catalisadores usados no ensaio de durabilidade

\begin{tabular}{|l|c|r|r|c|}
\hline \multirow{2}{*}{ Catalisador } & \multicolumn{2}{|c|}{ Tamanho do cristalito } & \multicolumn{2}{c|}{ Parâmetro de rede } \\
\cline { 2 - 5 } & Antes & Depois & Antes & Depois \\
\hline $\begin{array}{l}\mathrm{Pt}_{3} \mathrm{Sn} / \mathrm{C} \\
(\text { ânodo) }\end{array}$ & $4,1 \mathrm{~nm}$ & $3,9 \mathrm{~nm}$ & $0,3958 \mathrm{~nm}$ & $0,3934 \mathrm{~nm}$ \\
\hline $\mathrm{Pt} / \mathrm{C}$ (cátodo) & $2,53 \mathrm{~nm}$ & $4,01 \mathrm{~nm}$ & $0,3914 \mathrm{~nm}$ & $0,3926 \mathrm{~nm}$ \\
\hline
\end{tabular}

Com o intuito de obter informações mais precisas e confiáveis sobre degradação do catalisador, e exclusivamente para o estudo da estabilidade intrínseca do cátodo, investigações exsitu em células eletroquímicas são ferramentas muito úteis. Tais testes permitem um melhor controle das condições de degradação a que o catalisador é submetido.

Desta forma, foram analisadas imagens de TEM dos diferentes catalisadores antes e depois dos ensaios de estabilidade, junto com a correspondente curva de distribuição de tamanhos de partícula. Na Figura 36 podem-se observar as imagens e os histogramas do catalisador utilizado como ânodo, $\mathrm{Pt}_{3} \mathrm{Sn} / \mathrm{C}$ antes e depois do ensaio de estabilidade.

Um dos mecanismos de degradação, ou seja, crescimento das partículas parece ser dominante para o caso do cátodo que opera sob as condições de elevado potencial. No entanto, 


\section{Capítulo IV}

as indicações de uma sobreposição de vários mecanismos de degradação que ocorrem durante os testes são a causa da desativação do catalisador. Isto é provavelmente devido à composição do material e a concomitante, interação desigual metal-suporte. São observados no cátodo evidências de fenômenos Ostwald ripening, (97) mecanismo definido como o processo em que partículas grandes crescem, partículas menores dissolvem-se e difundem para aderir sobre as partículas maiores, o que resulta em uma redução no número total de partículas, com aumento do tamanho.

Figura 36 Micrografias e histogramas do ânodo após testes de estabilidade.
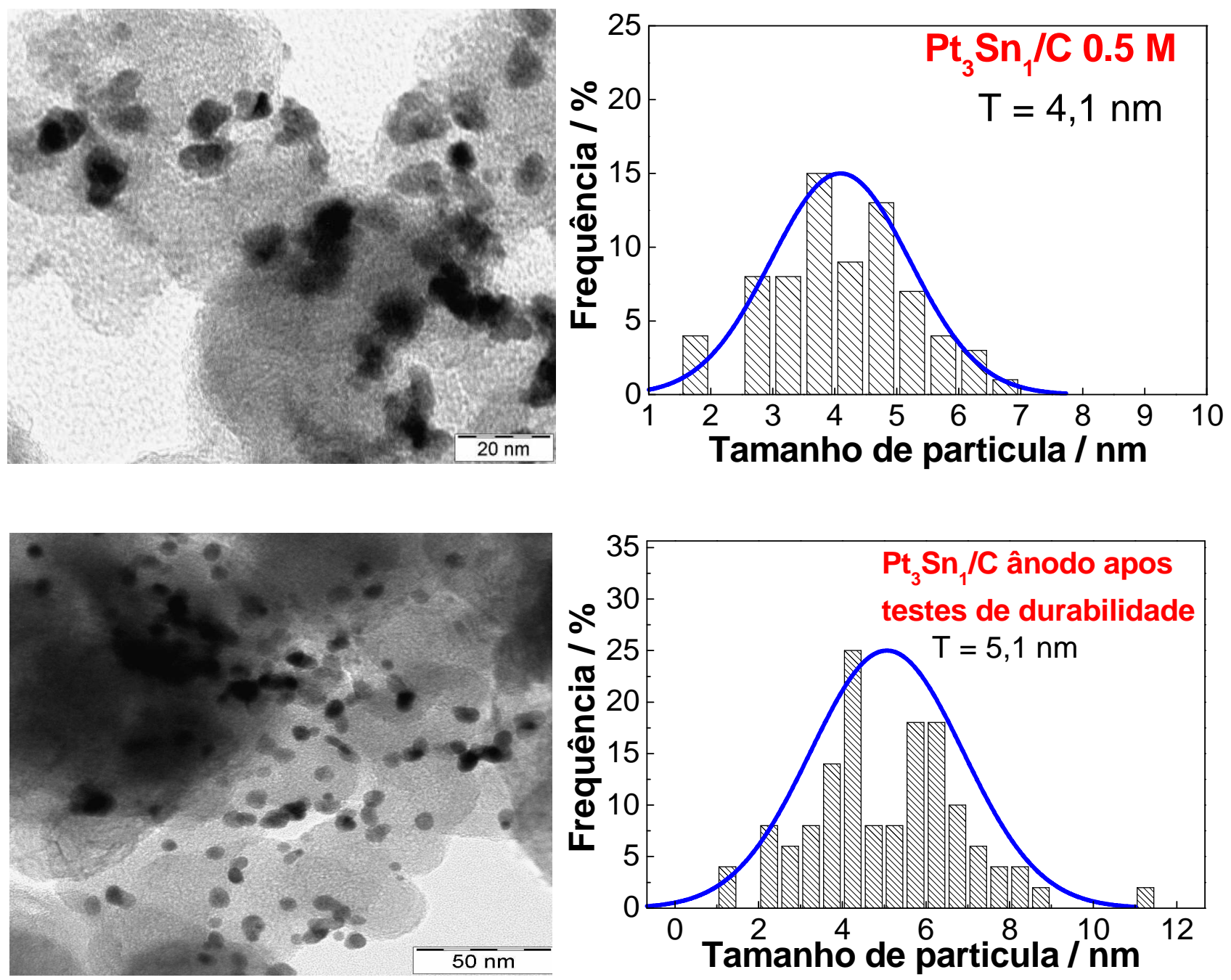

Na figura 37 observa-se que ocorre um leve incremento do tamanho da partícula durante o teste de estabilidade. Como comentado anteriormente, a operação a potenciais elevados, como é o caso do cátodo, favorece a dissolução da platina, a qual, quando o potencial apresenta decaimento nos períodos de parada, pode se redepositar sobre a superfície das partículas ainda 


\section{Capítulo IV}

presentes, conduzindo à formação de partículas maiores, mediante fenômenos de coalescência ou dissolução/redeposição.

Através de uma variedade de pesquisas sobre a estabilidade e durabilidade de eletrocatalisadores em células a combustível (98-103) procurou-se apresentar uma visão geral desta problemática. A clara ligação entre todos estes parâmetros e sua influência sobre a cinética do mecanismo de degradação individuais, no entanto, ainda está ausente e tem de ser estabelecida para desenvolver estratégias para melhorar a estabilidade do catalisador.

Figura 37 Micrografias e histogramas do cátodo após testes de estabilidade.
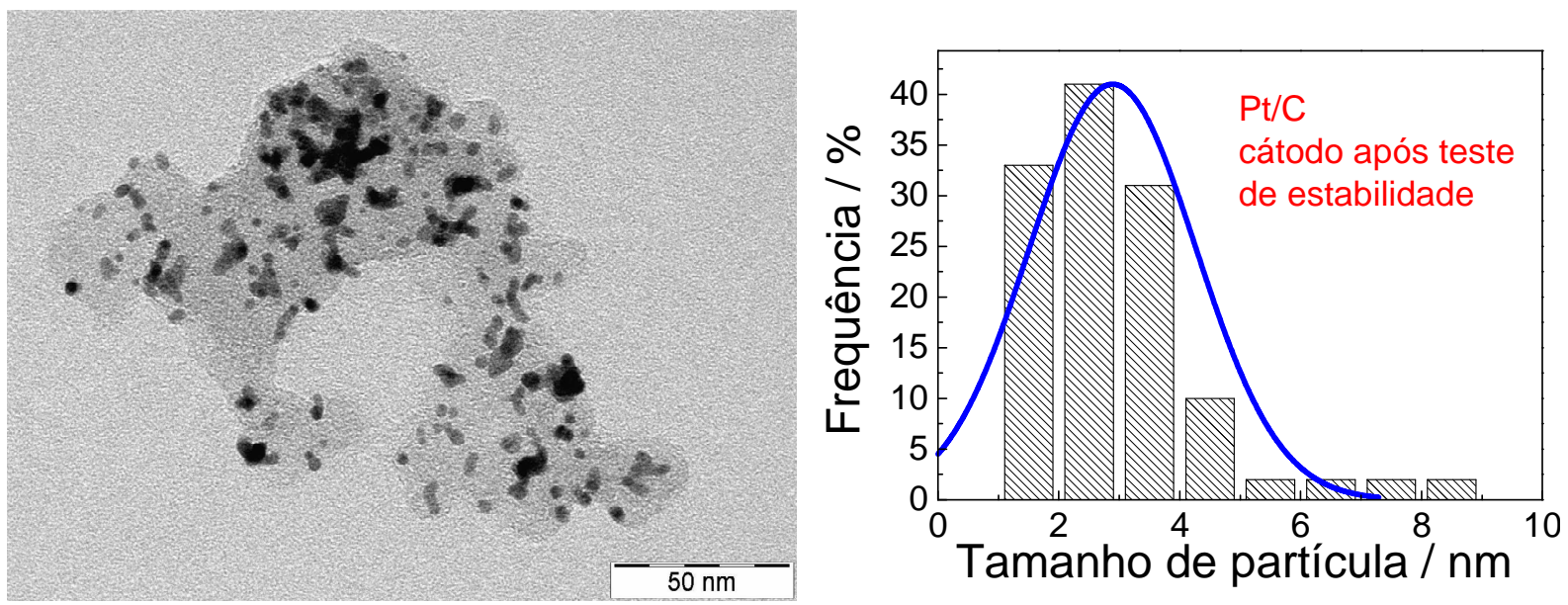

Após os testes intermitentes de ligado/desconexão foram prepados outros MEAS para estudo em célula a combustível de etanol direto. Com o intuito de estudar um sistema operando continuamente, com recirculação de etanol, montou-se um sistema e verificou-se a estabilidade por $220 \mathrm{~h}$. Na figura 38 pode-se observar um teste contínuo a $0,4 \mathrm{~V}$ a uma temperatura de $90{ }^{\circ} \mathrm{C} \mathrm{e}$ 2 Bar de pressão no cátodo e recirculação de uma solução de etanol 1M. 


\section{$\underline{\text { Capítulo IV }}$}

Figura 38 Teste de estabilidade realizado por 220 h em $0,4 \mathrm{~V}$ do catalisador de $\mathrm{PtSn} / \mathrm{C}$ com recirculação de etanol.

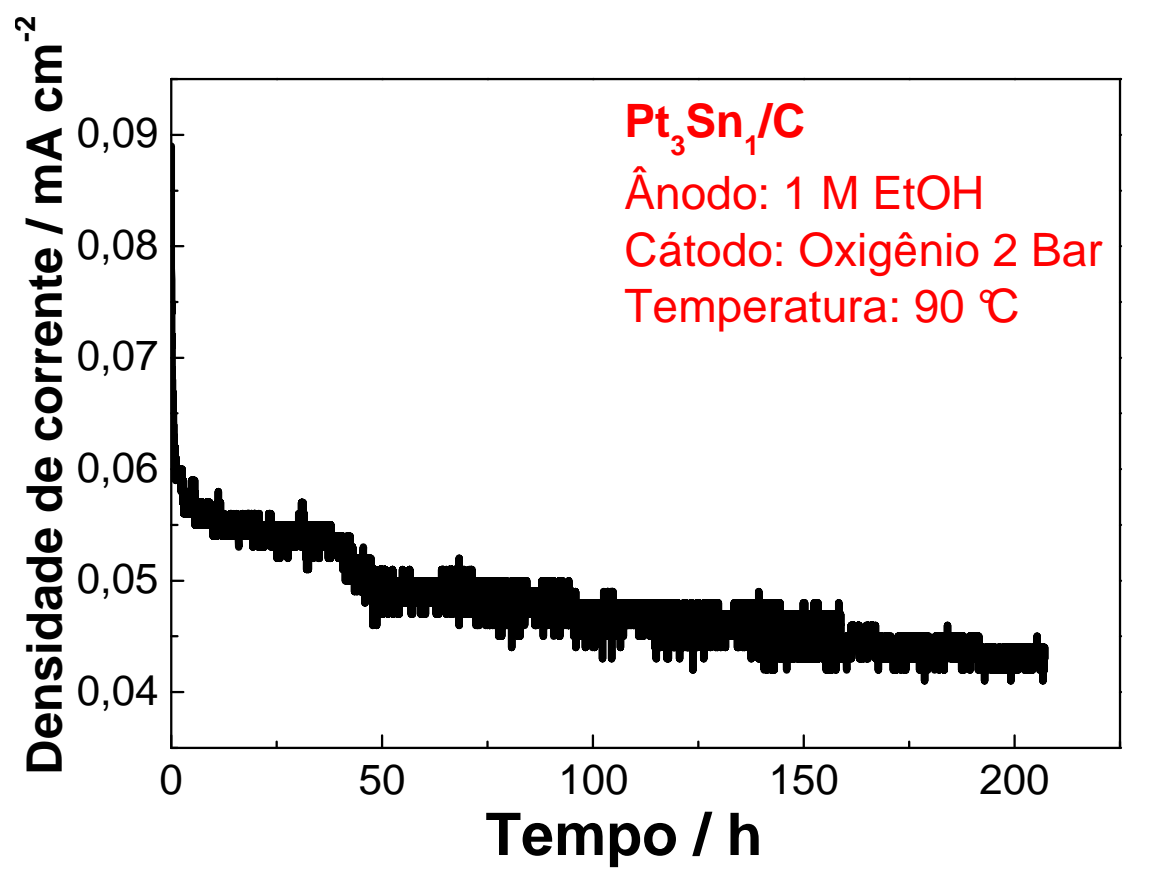

Pode-se observar que no caso da célula operar em maneira contínua também ocorre com o passar do tempo a queda na densidade de corrente. Neste caso o sistema manteve-se mais estável em relação ao primeiro teste apresentado anteriormente. Em primeiro plano pode-se dizer que quando uma célula opera continuamente o desgaste é muito menor, a corrosão dos materias ocorre em menor extensão quando comparado a uma célula que opera com ciclos de liga/desconexão como funcionam na realidade os sistemas práticos. Mench et al., (104) relatam que a dinâmica durante os ciclos de ligado/desconexão de células a combustível são extremamente prejudiciais para o catalisador e muitas vezes têm uma influência dominante sobre a sua durabilidade. (105) A razão principal para a degradação do catalisador é que o potencial do cátodo pode subir para valores acima de 1,5 V durante a fase inicial em que o gás combustível purgado é insuficiente, fazendo com que ocorra o envelhecimento do suporte de carbono, bem como as nanopartículas platina. Além disso, como demonstrado por Kinoshita et al., (106) a deterioração do catalisador é especialmente grave quando o potencial do eletrodo é alterado, em contraste com potenciais estáticos de funcionamento. Isto pode explicar a perda brusca de densidade de corrente do teste intermitente em comparação com o teste contínuo.

Neste segundo teste os eletrodos também são investigados por EIS com o intuito de se obter maiores detalhes dos processos responsáveis pela queda de desempenho que ocorre na célula durante a operação contínua. O diâmetro do arco aumenta e move-se na direção positiva 


\section{$\underline{\text { Capítulo IV }}$}

refletindo um aumento na resistência de transferência de carga dentro da camada catalisadora à medida que ocorre o processo de degradação.

$\mathrm{Na}$ Figura 39 são exibidas as medidas de impedância obtidas com a célula nas mesmas condições em que foram obtidas as curvas de polarização. Em geral os espectros de impedância apresentam o mesmo perfil no início e no final dos testes de estabilidade indicando que o teste contínuo apresentou menor desgaste da camada catalítica e do MEA em geral.

Figura 39 Espectros de impedância antes e após o teste de estabilidade de 220h.

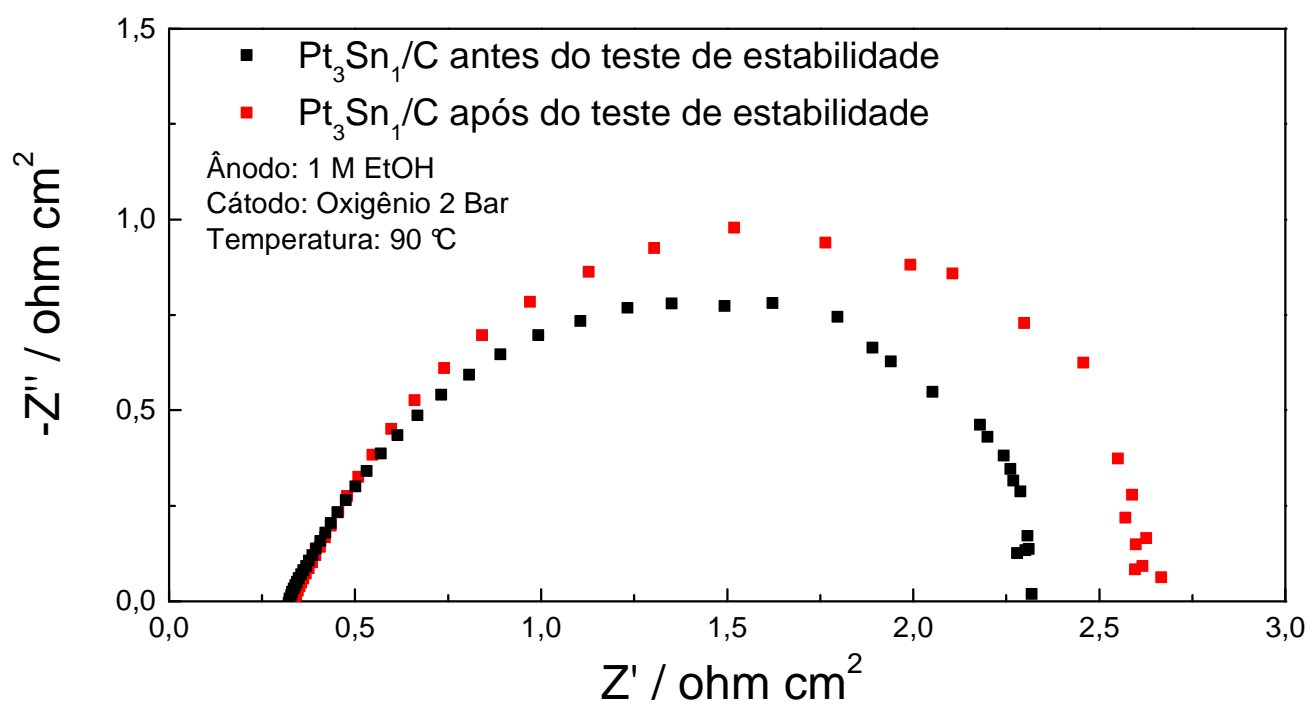

A degradação do material suportado em carbono é fortemente dependente da estrutura e composição, bem como as condições de funcionamento. (107) Um campo altamente complexo de parâmetros é estendido em torno das propriedades do catalisador em função da degradação, tais como a carga de platina, tamanho de partícula, ou a distribuição espacial das partículas, e o respectivo potencial de trabalho, $\mathrm{pH}$, temperatura, (108) e das impurezas como fatores mais importantes.

Knights at al.,(109) estudaram severas condições de operação de uma DMFC incluindo baixos fluxos de reagentes, níveis de umidificação e altas e baixas temperaturas em função de testes de durabilidade. Os possíveis efeitos dessas condições, junto com possíveis estratégias de mitigação em testes de longa duração. Neste estudo pode-se observar que os sistemas que trabalham com combustíveis liquidos não sofrem de problemas de ressecamento, mas são particularmente propensas ao encharcamento do cátodo. Isto quer dizer que uma porção significativa de água na corrente de combustível, atravessa para o cátodo resultando em um aumento da perda de transporte massa. Isso é devido à dificuldade dos reagentes difundirem-se através do vapor de água e /ou líquido presente que devem ser removidas pelo cátodo. As 


\section{Capítulo IV}

DAFCs exigem diferentes estratégias de gestão da água comparado as PEMFC. (110) Uma estratégia que pode ser utilizada para recuperar a perda de desempenho é a ciclagem. Quando se opera com carga constante, as células tendem a sofrer degradação do desempenho, devido a um aumento nas limitações de difusão de gás como é o caso da água que se acumula no cátodo.

Figura 40 Curvas de polarização em intervalos diferentes do ensaio de estabilidade.

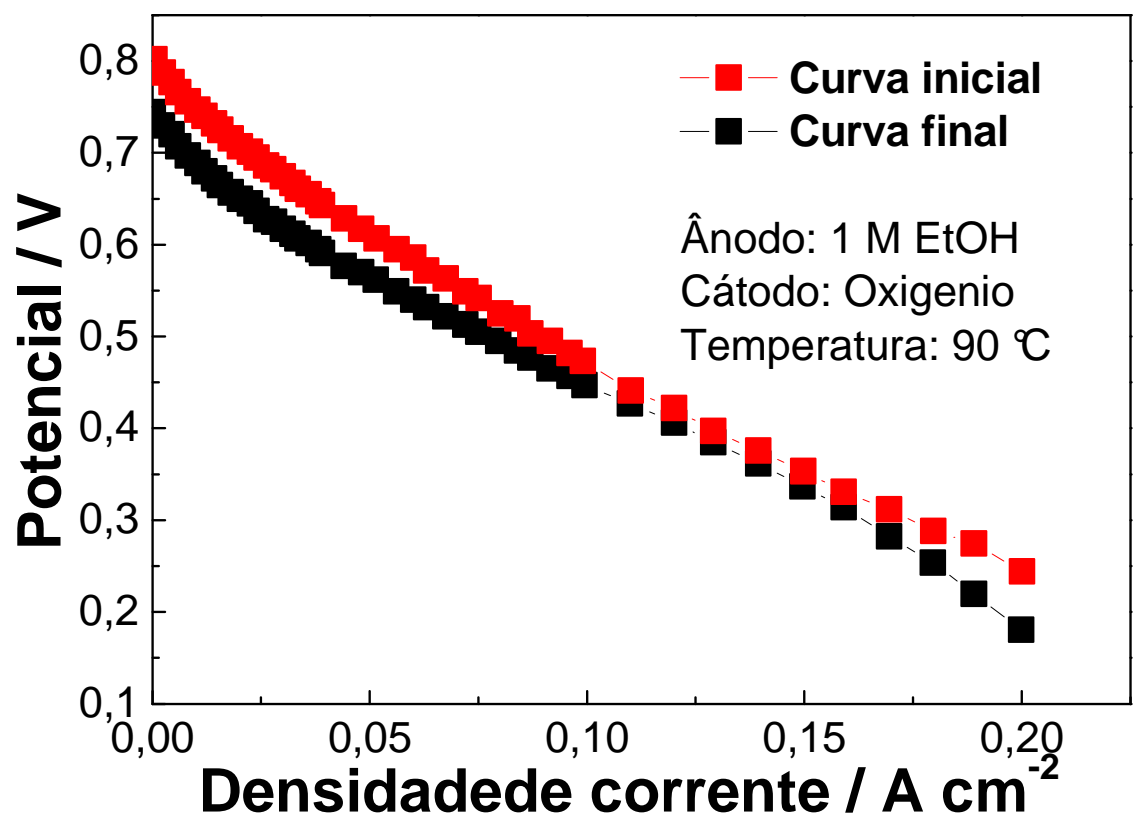

Análise de voltametria cíclica mostrada na figura 41, de forma semelhante as curvas de polarização figura 40, tem sido realizadas em intervalos de tempo específico. Os perfis de CV mostram uma forte diminuição da intensidade dos picos voltamétricos na região de adsorçãodessorção de hidrogênio durante a operação. Simultaneamente, a ocorrência de um pico de extração relacionado com resíduos orgânicos fortemente adsorvidos é observada até o final da região de dupla camada. Evitado o limite de potencial anódico além do intervalo de estabilidade intrínseca do catalisador, minimizaram-se efeitos de dissolução do metal que afetam o comportamento eletroquímico da célula durante a operação normal. Sayin at al., (111) analisaram através de voltametria cíclica (VC) e eletrodo de disco rotatório (EDR). Testes de degradação acelerada, foram aplicados antes e após os testes com catalisadores comerciais e eletrocatalisadores preparados afim de determinar a dissolução e aglomeração de platina e verificar possíveis efeitos com a corrosão de carbono. Os resultados mostraram que não houve uma perda significativa no potencial devido à dissolução e aglomeração de Pt. Por outro lado, foi observado que ocorreram consideráveis perdas de potencial devido a corrosão carbono. 
Capítulo IV

Figura 41 Voltametrias cíclias em célula unitária a intervalos diferentes do ensaio de estabilidade






\section{Conclusôes}

\section{CONCLUSÕES}

Os resultados obtidos mostram primeiramente que o teor de Sn aumentou com a quantidade de precursor de Sn e que apenas uma fração do conteúdo total foi de estanho sob a forma de liga. As curvas de polarização obtidas na célula a combustível unitária, alimentada diretamente por etanol, estão de acordo com os resultados de voltametria e cronoamperometria constatando o efeito benéfico da metodologia usada na preparação dos eletrocatalisadores, comprovando desta meneira que os eletrocatalisadores de $\mathrm{PtSn} / \mathrm{C}$ são efetivos para a eletrooxidação do etanol.

O catalisador que teve maior performance foi $\mathrm{Pt}_{3} \mathrm{Sn}_{1} / \mathrm{C}$ preparado com $0,5 \mathrm{M}$, esta composição foi dedicada para estudos de estabilidade em célula em dois testes como teste a potencial constante por $250 \mathrm{~h}$ e teste contínuo por $220 \mathrm{~h}$. O comportamento eletroquímico da DEFC foi afetado por perdas recuperáveis e irrecuperáveis, as primeiras estão associadas à cobertura de resíduos orgânicos adsorvidos da oxidação do etanol, essencialmente espécies que consistem principalmente em ácido acético e acetaldeído. Isto provoca uma diminuição drástica de desempenho no início da operação em cada ciclo. Depois, o desempenho atinge uma condição de estado estacionário. Contudo, o procedimento de desligamento afeta significativamente o desempenho do ciclo sucessivo. Observa-se que a célula de descarga em água pura a baixo potencial $(0.2 \mathrm{~V})$ durante o desligamento é benéfica para a célula uma vez que este procedimento promove a remoção de espécies adsorvidas.

Por outro lado um grande sobrepotencial no ânodo, correspondente a um potencial baixo da célula, pode favorecer o desligamento do metal de estanho que formava liga com a platina. No entanto, esta abordagem é preferível para a célula em OCV, o último processo promove o acúmulo de resíduos orgânicos sobre a superfície do ânodo. Um ajuste adequado das condições de desligamento pode melhorar o comportamento cíclico da DEFC. Perdas irrecuperáveis são preocupantes com o crescimento da partícula que parece ser moderado, tanto ânodo e cátodo (o intervalo de operação para ambos os eletrodos não está envolvendo altos potenciais eletroquímicos). $\mathrm{O}$ aspecto mais crítico em relação às perdas irrecuperáveis parece relacionado com a corrosão do metal menos nobre, o Sn a partir de Pt uma vez que isso pode afetar a capacidade de remover as espécies adsorvidas no ânodo que aparecem para determinar a etapa determinante da velocidade de todo o processo.

Outros fenômenos que podem desfavorecer a estabilidade do sistema têm a ver com processos de aglomeração das partículas metálicas durante a operação por tempos prolongados. 


\section{TRABALHOS PUBLICADOS NO PERÍODO DO DOUTORADO}

1. ZIGNANI, S.C.; BAGLIO, V.; LINARES, J.J; MONFORTE, G.; GONZALEZ, E.R; ARICÒ.A.S. Performance and selectivity of PtxSn/C electro-catalysts for ethanol oxidation prepared by reduction with different formic acid concentrations. Electrochimica Acta v. 70 p. 255-265, 2012.

2. ZIGNANI, S. C.; GONZALEZ, E. R.; BAGLIO, V.; SIRACUSANO, S.; ARICÒ, A. S. Investigation of a Pt3Sn/C Electro-Catalyst in a Direct Ethanol Fuel Cell operating at low temperatures for portable applications. International Journal of Electrochemical Science. v.7, p. 3155-3166, 2012.

3. LINARES, J.J.; ROCHA A. T..; ZIGNANI, S. C.; PAGANIN, V. A.; GONZALEZ, E.R. Different anode catalyst for high temperature polybenzimidazole-based direct ethanol fuel cells. International Journal of Hydrogen Energy. v. 38, p. 620-630, 2013.

4. LINARES, J.J.; ZIGNANI, S. C.; ROCHA A. T..; GONZALEZ,E.R. Ethanol oxidation on a high temperature PBI-based DEFC using $\mathrm{Pt} / \mathrm{C}, \mathrm{PtRu} / \mathrm{C}$ and $\mathrm{Pt}_{3} \mathrm{Sn} / \mathrm{C}$ as catalysts. Journal of Applied Electrochemistry. v.43, p.147-158, 2013.

5. ZIGNANI, S. C.; BAGLIO, V.; LINARES, J.J.; MONFORTE, G.; GONZALEZ, E.R; ARICÒ.A.S. Endurance study of a solid polymer electrolyte direct ethanol fuel cell based on a Pt-Sn anode catalyst. International Journal of Hydrogen Energy. In Press. 


\section{Sabrina Campagna Zignani}

\section{TRABALHOS FUTUROS}

O projeto a ser realizado como pós doutorado, busca estudar catalisadores alternativos a serem utilizados em células a combustível de etanol/ $\mathrm{O}_{2}$ e avaliar a eficiência, assim como a capacidade para a remoção dos intermediários reacionais. Neste sentido, catalisadores bimetálicos com diferentes composições e graus de interação entre os componentes deverão ser pesquisados, visando-se maximizar os rendimentos na célula em termos de densidade de corrente, bem como na medida do possível de eficiência em termos de produção de $\mathrm{CO}_{2}$, bem como o estudo da estabilidade destes materiais, analisando-se principalmente a estabilidade do segundo metal. Uma vez estabelecido o segundo metal mais adequado na preparação do catalisador, avaliar-se-á a possibilidade da adição de um terceiro elemento, metal ou óxido, com o objetivo de melhorar ainda mais o desempenho obtido nas etapas anteriores. Finalmente, a possibilidade de aplicação destes catalisadores em células a combustível DAFC de alta temperatura $\left(120-200^{\circ} \mathrm{C}\right)$ também será investigada.

O objetivo geral deste projeto será o desenvolvimento de uma célula a combustível de alcool direto com:

- Desenvolvimento de catalisadores bi-metálicos: Pt-Ru, Pt-Sn, Pt-W e Pt-Rh. Análise de diferentes procedimentos de deposição e condições dos mesmos.

- Estabelecido o método mais adequado para cada um das composições binárias mencionadas anteriormente, avaliar-se-á a estabilidade a longos tempos de cada um deles, visando-se estabelecer qual deles é o que apresenta maior resistência à degradação, e qual é o mecanismo que permite isto. Estabelecer-se-á a relação entre o grau de segregação do segundo metal e a estabilidade do mesmo.

- Sobre a base dos resultados anteriores, e levando em consideração qual é o mecanismo preponderante que determina a melhora no rendimento, estudar-se-á a possibilidade da adição de um terceiro metal (ou óxido).Visar-se-á igualmente a influência da presença deste terceiro componente na estabilidade dos catalisadores tri-metálicos preparados. 
Tese de doutorado

Sabrina Campagna Zignani

\section{ANEXOS}

Figura A1 Estação automática de testes utilizada para alimentação das células e medidas eletroquímicas.

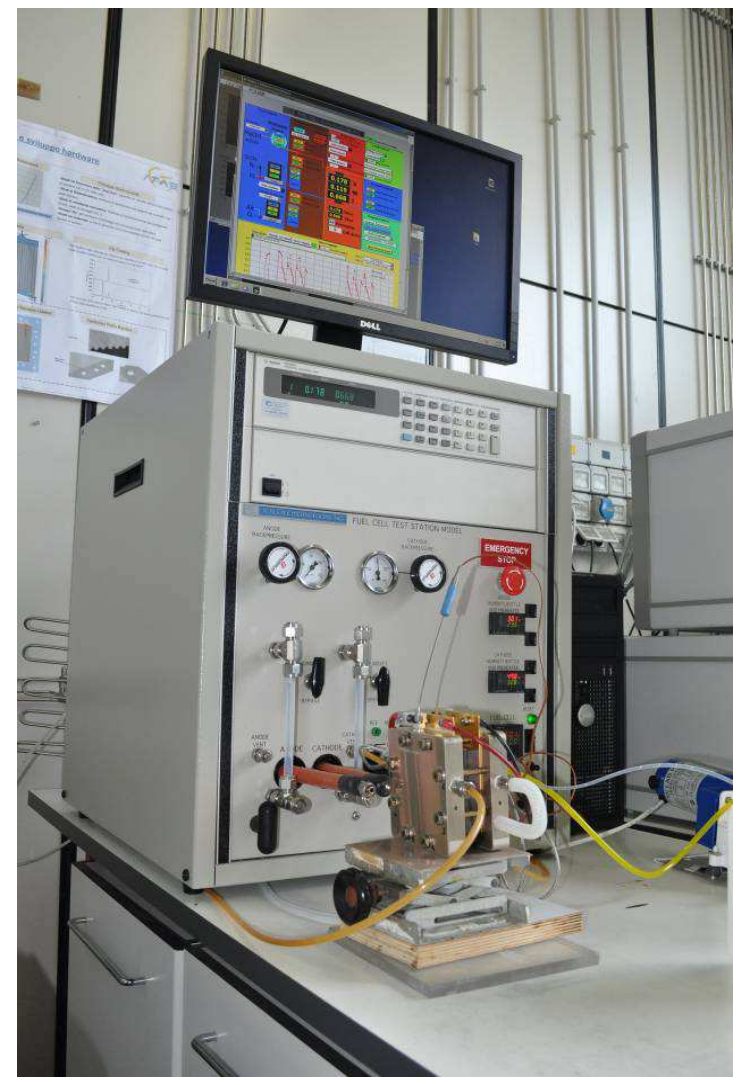

Figura A2 Célula unitária usada para os exprimentos




Tese de doutorado

Sabrina Campagna Zignani

Figura A3 Esquema de uma célula a combustível e do MEA

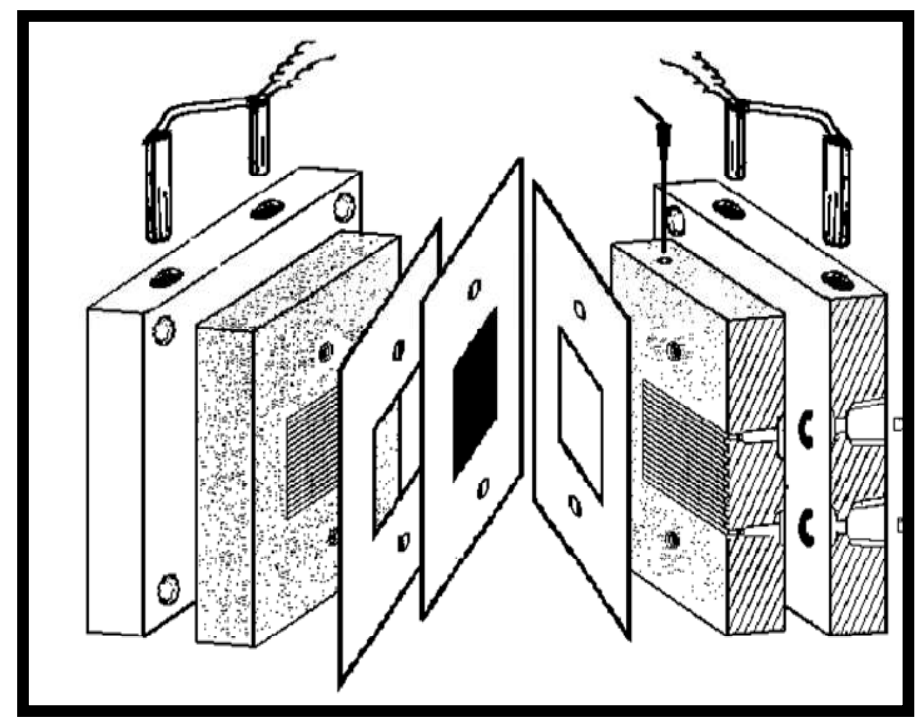


Tese de doutorado

Sabrina Campagna Zignani

\section{REFERÊNCIAS BIBLIOGRÁFICAS}

1 AL-CHALABI, F. J. OPEC and the international oil industry: a changing structure. Oxford: Oxford University, 1981. 176 p.

2 ROdRIGUES, A. P.; FERNÁNDEZ, E.; BUENO, J. Política energética para o Brasil: propostas para o crescimento sustentável. São Paulo: Nova Fronteira, 2006. 335 p.

3 VILLULLAS, H. M.; TICIANELLI, E. A.; GONZALEZ, E. R. Células a combustível: energia limpa a partir de fontes renováveis. Química Nova na Escola, v. 15, p. 28-34, 2002.

4 COSTAMAGNA, P.; SRINIVASAN, S. Quantum jumps in the PEMFC science and technology from the 1960s to the year 2000: Part II. Engineering, technology development and application aspects. Journal of Power Sources, v. 102, p. 253-269, 2001.

5 KORDESCH, K.; SIMADER, G. R. Fuel cells and their applications. New York: John Wiley \& Sons, 1996. 375 p.

6 EG\&G TECHNICAL SERVICES. Fuel cell handbook. 7 ed. Morgantown: U.S. Nacional Energy Technology, 2004. 427 p.

7 GASTEIGER, H. A.; MARKOVIC, N. M.; ROSS, P. N. H2 and CO electrooxidation on wellcharacterized $\mathrm{Pt}, \mathrm{Ru}$, and $\mathrm{Pt}-\mathrm{Ru}$. 1. rotating disk electrode studies of the pure gases including temperature effects. The Journal of Physical Chemistry, v. 99, p. 8290-8301, 1995.

8 CIAPINA, E. G.; GONZALEZ, E. R. Investigation of the electro-oxidation of CO on Ptbased carbon supported catalysts (Pt75Sn25/C, Pt65Ru35/C and Pt/C) by electrochemical impedance spectroscopy. Journal of Electroanalytical Chemistry, v. 626, p. 130-142, 2009.

9 GASTEIGER, H. A.; MARKOVIC, N.; ROSS, P. N.; CAIRNS, E. J. Carbon monoxide electrooxidation on well-characterized platinum-ruthenium alloys. The Journal of Physical Chemistry, v. 98, p. 617-625, 1994.

10 CAMARA, G. A.; DE LIMA, R. B.; IWASITA, T. The influence of PtRu atomic composition on the yields of ethanol oxidation: A study by in situ FTIR spectroscopy. Journal of Electroanalytical Chemistry, v. 585, p. 128-131, 2005.

11 LIMA, F. H. B.; DE CASTRO, J. F. R.; SANTOS, L. G. R. A.; TICIANELLI, E. A. Electrocatalysis of oxygen reduction on carbon-supported $\mathrm{Pt}-\mathrm{Co}$ nanoparticles with low $\mathrm{Pt}$ content. Journal of Power Sources, v. 190, p. 293-300, 2009.

12 DICKS, A. L. The role of carbon in fuel cells. Journal of Power Sources, v. 156, p. 128-141, 2006.

13 KINOSHITA, K.; STONEHART, P. Preparation and characterization of highly dispersed electrocatalytic materials. In: BOCKRIS, J.O.M.; CONWAY, B.E. Modern aspects of electrochemistry. New York:Plenem, 1977. v. 12, p. 189-266. 
Tese de doutorado

Sabrina Campagna Zignani

14 GUILMINOT, E.; CORCELLA, A.; CHARLOT, F.; MAILLARD, F.; CHATENET, M. Detection of $\mathrm{Pt} z+$ ions and pt nanoparticles inside the membrane of a used PEMFC. Journal of The Electrochemical Society, v. 154, p. B96-B105, 2007.

15 LO FARO, M.; ANTONUCCI, V.; ANTONUCCI, P. L.; ARICÒ, A. S. Fuel flexibility: A key challenge for SOFC technology. Fuel, v. 102, p. 554-559, 2012.

16 JUSTI, E. W.; WINSEL, A. W. The DSK system of fuel cell electrodes. Journal of The Electrochemical Society, v. 108, p. 1073-1079, 1961.

17 AMENDOLA, S. C.; ONNERUD, P.; KELLY, M. T.; PETILLO, P. J.; SHARPGOLDMAN, S. L.; BINDER, M. A novel high power density borohydride-air cell. Journal of Power Sources, v. 84, p. 130-133, 1999.

18 AN, L.; ZHAO, S.T.; XU, B.J. A bi-functional cathode structure for alkaline-acid direct ethanol fuel cells. International Journal of Hydrogen Energy. v.36, p. 13089-13095, 2011.

19 LINARDI, M. Introdução à ciência e tecnologia de células a combustível. São Paulo: ARTLIBER.. 2010. 152 p.

20 SILVA, V. S.; MENDES, A.; MADEIRA, L. M.; NUNES, S. P. Proton exchange membranes for direct methanol fuel cells: Properties critical study concerning methanol crossover and proton conductivity. Journal of Membrane Science, v. 276, p. 126-134, 2006.

21 TICIANELLI, E. A.; GONZALEZ, E. R. Eletroquímica: princípios e aplicações. São Paulo: EDUSP, 1998. v. 17. 235 p.

22 GASTEIGER, H. A.; KOCHA, S. S.; SOMPALLI, B.; WAGNER, F. T. Activity benchmarks and requirements for Pt, Pt-alloy, and non-Pt oxygen reduction catalysts for PEMFCs. Applied Catalysis B: Environmental, v. 56, p. 9-35, 2005.

23 AMPHLET'T, J. C.; BAUMERT, R. M.; MANN, R. F.; PEPPLEY, B. A.; ROBERGE, P. R.; HARRIS, T. J. Performance modeling of the ballard mark iv solid polymer electrolyte fuel cell: $i$. mechanistic model development. Journal of The Electrochemical Society, v. 142, p. 1-8, 1995.

24 PAGANIN, V. A.; TICIANELLI, E. A.; GONZALEZ, E. R. Development and electrochemical studies of gas diffusion electrodes for polymer electrolyte fuel cells. Journal of Applied Electrochemistry, v. 26, p. 297-304, 1996.

25 ZHANG, S.; YUAN, X.-Z.; HIN, J. N. C.; WANG, H.; FRIEDRICH, K. A.; SCHULZE, M. A review of platinum-based catalyst layer degradation in proton exchange membrane fuel cells. Journal of Power Sources, v. 194, p. 588-600, 2009.

26 PATIL, Y.; SAMBANDAM, S.; RAMANI, V.; MAURITZ, K. Model studies of the durability of a titania-modified nafion fuel cell membrane. Journal of The Electrochemical Society, v. 156, p. B1092-B1098, 2009. 
Tese de doutorado

Sabrina Campagna Zignani

27 REN, X.; SPRINGER, T. E.; GOTTESFELD, S. Water and methanol uptakes in nafion membranes and membrane effects on direct methanol cell performance. Journal of The Electrochemical Society, v. 147, p. 92-98, 2000.

28 SONG, S.; WANG, G.; ZHOU, W.; ZHAO, X.; SUN, G.; XIN, Q.; KONTOU, S.; TSIAKARAS, P. The effect of the MEA preparation procedure on both ethanol crossover and DEFC performance. Journal of Power Sources, v. 140, p. 103-110, 2005.

29 ZHAO, T. S.; CHEN, R.; EDITOR-IN-CHIEF:Â Â JÃRGEN, G. Encyclopedia of electrochemical power sources. Amsterdam: Elsevier, 2009, p. 428-435.

30 WILSON, M. S.; GARZON, F. H.; SICKAFUS, K. E.; GOTTESFELD, S. surface area loss of supported platinum in polymer electrolyte fuel cells. Journal of The Electrochemical Society, v. 140, p. 2872-2877, 1993.

31 WANG, X.; KUMAR, R.; MYERS, D. J. Effect of voltage on platinum dissolution: relevance to polymer electrolyte fuel cells. Electrochemical and Solid-State Letters, v. 9, p. A225-A227, 2006.

32 SHAO, Y.; YIN, G.; GAO, Y.; SHI, P. Durability Study of Pt/C and Pt/CNTs catalysts under simulated PEM fuel cell conditions. Journal of The Electrochemical Society, v. 153, p. A1093A1097, 2006.

33 MAYRHOFER, K. J. J.; MEIER, J. C.; ASHTON, S. J.; WIBERG, G. K. H.; KRAUS, F.; HANZLIK, M.; ARENZ, M. Fuel cell catalyst degradation on the nanoscale. Electrochemistry Communications, v. 10, p. 1144-1147, 2008.

34 ZIGNANI, S. C.; ANTOLINI, E.; GONZALEZ, E. R. Evaluation of the stability and durability of $\mathrm{Pt}$ and $\mathrm{Pt}-\mathrm{Co} / \mathrm{C}$ catalysts for polymer electrolyte membrane fuel cells. Journal of Power Sources, v. 182, p. 83-90, 2008.

35 SHAO, Y.; YIN, G.; WANG, Z.; GAO, Y. Proton exchange membrane fuel cell from low temperature to high temperature: Material challenges. Journal of Power Sources, v. 167, p. 235242, 2007.

36 XIE, J.; WOOD, D. L.; WAYNE, D. M.; ZAWODZINSKI, T. A.; ATANASSOV, P.; BORUP, R. L. Durability of PEFCs at high humidity conditions. Journal of The Electrochemical Society, v. 152, p. A104-A113, 2005.

37 DEBE, M. K.; SCHMOECKEL, A. K.; VERNSTROM, G. D.; ATANASOSKI, R. High voltage stability of nanostructured thin film catalysts for PEM fuel cells. Journal of Power Sources, v. 161, p. 1002-1011, 2006.

38 JIANG, L.; SUN, G.; WANG, S.; WANG, G.; XIN, Q.; ZHOU, Z.; ZHOU, B. Electrode catalysts behavior during direct ethanol fuel cell life-time test. Electrochemistry

Communications, v. 7, p. 663-668, 2005.

39 BORUP, R. L.; DAVEY, J. R.; GARZON, F. H.; WOOD, D. L.; INBODY, M. A. PEM fuel cell electrocatalyst durability measurements. Journal of Power Sources, v. 163, p. 76-81, 2006. 
Tese de doutorado

Sabrina Campagna Zignani

40 HANSEN, A. C.; ZHANG, Q.; LYNE, P. W. L. Ethanol-diesel fuel blends - a review. Bioresource Technology, v. 96, p. 277-285, 2005.

41 WYMAN, C. E. Biomass Ethanol: Technical Progress, Opportunities, and Commercial Challenges. Annual Review of Energy and the Environment, v. 24, p. 189-226, 1999.

42 ANTOLINI, E. Catalysts for direct ethanol fuel cells. Journal of Power Sources, v. 170, p. 1$12,2007$.

43 COUTANCEAU, C.; BRIMAUD, S.; LAMY, C.; LÉGER, J. M.; DUBAU, L.; ROUSSEAU, S.; VIGIER, F. Review of different methods for developing nanoelectrocatalysts for the oxidation of organic compounds. Electrochimica Acta, v. 53, p. 6865-6880, 2008.

44 IWASITA, T.; RASCH, B.; CATTANEO, E.; VIELSTICH, W. A sniftirs study of ethanol oxidation on platinum. Electrochimica Acta, v. 34, p. 1073-1079, 1989.

45 ARICÒ, A. S.; CRETI, P.; ANTONUCCI, P. L.; ANTONUCCI, V. Comparison of ethanol and methanol oxidation in a liquid-feed solid polymer electrolyte fuel cell at high temperature.

Electrochemical and Solid-State Letters, v. 1, p. 66-68, 1998.

46 LAMY, C.; ROUSSEAU, S.; BELGSIR, E. M.; COUTANCEAU, C.; LÉGER, J. M. Recent progress in the direct ethanol fuel cell: development of new platinum-tin electrocatalysts.

Electrochimica Acta, v. 49, p. 3901-3908, 2004.

47 TAYAL, J.; RAWAT, B.; BASU, S. Effect of addition of rhenium to Pt-based anode catalysts in electro-oxidation of ethanol in direct ethanol PEM fuel cell. International Journal of Hydrogen Energy, v. 37, p. 4597-4605. 2012.

48 ZHOU, W.; ZHOU, Z.; SONG, S.; LI, W.; SUN, G.; TSIAKARAS, P.; XIN, Q. Pt based anode catalysts for direct ethanol fuel cells. Applied Catalysis B: Environmental, v. 46, p. 273 285, 2003.

49 ALCALA, R.; SHABAKER, J. W.; HUBER, G. W.; SANCHEZ-CASTILLO, M. A.; DUMESIC, J. A. Experimental and DFT studies of the conversion of ethanol and acetic acid on PtSn-based catalysts. The Journal of Physical Chemistry B, v. 109, p. 2074-2085, 2004.

50 ZHOU, W. J.; LI, W. Z.; SONG, S. Q.; ZHOU, Z. H.; JIANG, L. H.; SUN, G. Q.; XIN, Q.; POULIANITIS, K.; KONTOU, S.; TSIAKARAS, P. Bi- and tri-metallic Pt-based anode catalysts for direct ethanol fuel cells. Journal of Power Sources, v. 131, p. 217-223, 2004.

51 WANG, H.; JUSYS, Z.; BEHM, R. J. Ethanol electro-oxidation on carbon-supported Pt, PtRu and Pt3Sn catalysts: A quantitative DEMS study. Journal of Power Sources, v. 154, p. 351-359, 2006.

52 LIU, P.; LOGADOTTIR, A.; NØRSKOV, J. K. Modeling the electro-oxidation of CO and H2/CO on Pt, Ru, PtRu and Pt3Sn. Electrochimica Acta, v. 48, p. 3731-3742, 2003.

53 LAMY, C.; BELGSIR, E. M.; EACUTE; GER, J. M. Electrocatalytic oxidation of aliphatic alcohols: Application to the direct alcohol fuel cell (DAFC). Journal of Applied Electrochemistry, v. 31, p. 799-809, 2001. 
Tese de doutorado

Sabrina Campagna Zignani

54 CAMARA, G. A.; IWASITA, T. Parallel pathways of ethanol oxidation: The effect of ethanol concentration. Journal of Electroanalytical Chemistry, v. 578, p. 315-321, 2005.

55 SOUZA, J. P. I.; BOTELHO RABELO, F. J.; DE MORAES, I. S. R.; NART, F. C.

Performance of a co-electrodeposited Pt-Ru electrode for the electro-oxidation of ethanol studied by in situ FTIR spectroscopy. Journal of Electroanalytical Chemistry, v. 420, p. 17-20, 1997.

56 SCHMIEMANN, U.; MÜLLER, U.; BALTRUSCHAT, H. The influence of the surface structure on the adsorption of ethene, ethanol and cyclohexene as studied by DEMS.

Electrochimica Acta, v. 40, p. 99-107, 1995.

57 LAMY, C.; LIMA, A.; LERHUN, V.; DELIME, F.; COUTANCEAU, C.; LÉGER, J.-M. Recent advances in the development of direct alcohol fuel cells (DAFC). Journal of Power Sources, v. 105, p. 283-296, 2002.

58 TICIANELLI, E. A. Eletrodos de difusão de gás. 1992 f Tese (Livre-docência) Instituto de Química de São Carlos, Universidade de São Paulo, São Carlos, 1992.

59 GONZALEZ, E. R.; TICIANELLI, E. A.; PINHEIRO, A. L. N.; PEREZ, J. Processo de obtenção de catalisador de platina dispersa ancorada em substrato através da redução por ácido. BR.P.I.9.702.816-9. 02 de setembro de 1997.

60 LOPES, T.; ANTOLINI, E.; GONZALEZ, E. R. Carbon supported Pt-Pd alloy as an ethanol tolerant oxygen reduction electrocatalyst for direct ethanol fuel cells. International Journal of Hydrogen Energy, v. 33, p. 5563-5570, 2008.

61 WEST, A. R. Solid state chemistry and its applications. New York: John Wiley \& Sons, 1984. p. 734

62 MOULDER, J. F.; CHASTAIN, J. Handbook of $\mathbf{x}$ ray photoelectron spectroscopy: a reference book of standard spectra for identification and interpretation of xps data. Norkwalk: Perkin-Elmer, 1992. 261 p.

63 TICIANELLI, E. A.; CAMARA, G. A.; SANTOS, L. G. R. A. Eletrocatálise das reações de oxidação de hidrogênio e de redução de oxigênio. Quimica Nova, v. 28, p. 664-669, 2005.

64 MILLINGTON, B.; WHIPPLE, V.; POLLET, B. G. A novel method for preparing proton exchange membrane fuel cell electrodes by the ultrasonic-spray technique. Journal of Power Sources, v. 196, p. 8500-8508. 2011.

65 PARK, G.-G.; SOHN, Y.-J.; YANG, T.-H.; YOON, Y.-G.; LEE, W.-Y.; KIM, C.-S. Effect of PTFE contents in the gas diffusion media on the performance of PEMFC. Journal of Power Sources, v. 131, p. 182-187, 2004.

66 ROUSSEAU, S.; COUTANCEAU, C.; LAMY, C.; LÉGER, J. M. Direct ethanol fuel cell (DEFC): Electrical performances and reaction products distribution under operating conditions with different platinum-based anodes. Journal of Power Sources, v. 158, p. 18-24, 2006. 
Tese de doutorado

Sabrina Campagna Zignani

67 ZIGNANI, S. C.; BAGLIO, V.; LINARES, J. J.; MONFORTE, G.; GONZALEZ, E. R.; ARICÒ, A. S. Performance and selectivity of PtxSn/C electro-catalysts for ethanol oxidation prepared by reduction with different formic acid concentrations. Electrochimica Acta, v. 70, p. 255-265. 2012.

68 COLMATI, F.; ANTOLINI, E.; GONZALEZ, E. R. Ethanol oxidation on a carbonsupported Pt75Sn25 electrocatalyst prepared by reduction with formic acid: Effect of thermal treatment. Applied Catalysis B: Environmental, v. 73, p. 106-115, 2007.

69 BATURINA, O. A.; AUBUCHON, S. R.; WYNNE, K. J. Thermal stability in air of Pt/C catalysts and PEM fuel cell catalyst layers. Chemistry of Materials, v. 18, p. 1498-1504, 2006.

70 LIU, Z.; GUO, B.; HONG, L.; LIM, T. H. Microwave heated polyol synthesis of carbonsupported PtSn nanoparticles for methanol electrooxidation. Electrochemistry

Communications, v. 8, p. 83-90, 2006.

71 KAMARUDIN, M. Z. F.; KAMARUDIN, S. K.; MASDAR, M. S.; DAUD, W. R. W. Review: Direct ethanol fuel cells. International Journal of Hydrogen Energy, 2012. In press.

72 CRISAFULLI, R.; O, NETO, A.; LINARDI, M.; SPINACÉ, E. V. Preparation of PtSn/C skeletal-type electrocatalyst for ethanol oxidation. Studies in Surface Science and Catalysis. v.175, p.559-562. 2010.

73 HOGARTH, M. P.; RALPH, T. R. Catalysis for low temperature fuel cells. Platinum Metals Review, v. 46, p. 146-164, 2002.

74 ZHOU, W. J.; SONG, S. Q.; LI, W. Z.; ZHOU, Z. H.; SUN, G. Q.; XIN, Q.;

DOUVARTZIDES, S.; TSIAKARAS, P. Direct ethanol fuel cells based on PtSn anodes: the effect of Sn content on the fuel cell performance. Journal of Power Sources, v. 140, p. 50-58, 2005.

75 ANTOLINI, E.; COLMATI, F.; GONZALEZ, E. R. Ethanol oxidation on carbon supported (PtSn)alloy/SnO2 and (PtSnPd)alloy/SnO2 catalysts with a fixed Pt/SnO2 atomic ratio: Effect of the alloy phase characteristics. Journal of Power Sources, v. 193, p. 555-561, 2009.

76 KANG, S.; LIM, S.; PECK, D.-H.; KIM, S.-K.; JUNG, D.-H.; HONG, S.-H.; JUNG, H.-G.; SHUL, Y. Stability and durability of PtRu catalysts supported on carbon nanofibers for direct methanol fuel cells. International Journal of Hydrogen Energy, v. 37, p. 4685-4693. 2012.

77 COLMATI JUNIOR, F.; LIZCANO-VALBUENA, W. H.; CAMARA, G. A.; TICIANELLI, E. A.; GONZALEZ, E. R. Carbon monoxide oxidation on Pt-Ru electrocatalysts supported on high surface area carbon. Journal of the Brazilian Chemical Society, v. 13, p. 474-482, 2002.

78 CUNHA, E. M.; RIBEIRO, J.; KOKOH, K. B.; DE ANDRADE, A. R. Preparation, characterization and application of $\mathrm{Pt}-\mathrm{Ru}-\mathrm{Sn} / \mathrm{C}$ trimetallic electrocatalysts for ethanol oxidation in direct fuel cell. International Journal of Hydrogen Energy, v. 36, p. 11034-11042. 2011. 
79 VIGIER, F.; COUTANCEAU, C.; PERRARD, A.; BELGSIR, E. M.; LAMY, C. Development of anode catalysts for a direct ethanol fuel cell. Journal of Applied Electrochemistry, v. 34, p. 439-446, 2004.

80 BÖNNEMANN, H.; BRIJOUX, W.; BRINKMANN, R.; JOUßEN, T.; KORALL, B.; DINJUS, E. Formation of colloidal transition metals in organic phases and their application in catalysis. Angewandte Chemie International Edition in English, v. 30, p. 1312-1314, 1991.

81 GOTZ, M.; WENDT, H. Binary and ternary anode catalyst formulations including the elements W, Sn and Mo for PEMFCs operated on methanol or reformate gas. Electrochimica Acta, v. 43, p. 3637-3644, 1998.

82 LI, H.; SUN, G.; CAO, L.; JIANG, L.; XIN, Q. Comparison of different promotion effect of $\mathrm{PtRu} / \mathrm{C}$ and PtSn/C electrocatalysts for ethanol electro-oxidation. Electrochimica Acta, v. 52, p. 6622-6629, 2007.

83 RODRIGUES DA SILVA, M.; ÃNGELO, A. Synthesis and characterization of ordered intermetallic nanostructured $\mathrm{ptsn} / \mathrm{c}$ and $\mathrm{ptsb} / \mathrm{c}$ and evaluation as electrodes for alcohol oxidation. Electrocatalysis, v. 1, p. 95-103. 2010.

84 JABLONSKI, A.; LEWERA, A. Electrocatalytic oxidation of ethanol on Pt, Pt-Ru and Pt-Sn nanoparticles in polymer electrolyte membrane fuel cell-Role of oxygen permeation. Applied Catalysis B: Environmental, v. 115 e 116, p. 25-30. 2012.

85 GUO, Y.; ZHENG, Y.; HUANG, M. Enhanced activity of PtSn/C anodic electrocatalyst prepared by formic acid reduction for direct ethanol fuel cells. Electrochimica Acta, v. 53, p. 3102-3108, 2008.

86 VIGIER, F.; COUTANCEAU, C.; HAHN, F.; BELGSIR, E. M.; LAMY, C. On the mechanism of ethanol electro-oxidation on Pt and PtSn catalysts: electrochemical and in situ IR reflectance spectroscopy studies. Journal of Electroanalytical Chemistry, v. 563, p. 81-89, 2004.

87 ALMEIDA, T. S.; PALMA, L. M.; LEONELLO, P. H.; MORAIS, C.; KOKOH, K. B.; DE ANDRADE, A. R. An optimization study of PtSn/C catalysts applied to direct ethanol fuel cell: Effect of the preparation method on the electrocatalytic activity of the catalysts. Journal of Power Sources, v. 215, p. 53-62, 2012.

88 CAMARA, G. A.; GOMES, J. F.; BERGAMASKI, K.; TEIXEIRA-NETO, E.; NART, F. C. CO electrooxidation on Pt nanoparticles in acidic solution: A FTIRS and DEMS study. Journal of Electroanalytical Chemistry, v. 617, p. 171-178, 2008.

89 SCHNEIDER, I. A.; BAYER, M. H.; WOKAUN, A.; SCHERER, G. G. Impedance response of the proton exchange membrane in polymer electrolyte fuel cells. Journal of The Electrochemical Society, v. 155, p. B783-B792, 2008.

90 FREIRE, T. J. P.; GONZALEZ, E. R. Effect of membrane characteristics and humidification conditions on the impedance response of polymer electrolyte fuel cells. Journal of

Electroanalytical Chemistry, v. 503, p. 57-68, 2001. 
91 WU, J.; YUAN, X. Z.; WANG, H.; BLANCO, M.; MARTIN, J. J.; ZHANG, J. Diagnostic tools in PEM fuel cell research: Part I Electrochemical techniques. International Journal of Hydrogen Energy, v. 33, p. 1735-1746, 2008

92 PAGANIN, V. A.; OLIVEIRA, C. L. F.; TICIANELLI, E. A.; SPRINGER, T. E.; GONZALEZ, E. R. Modelistic interpretation of the impedance response of a polymer electrolyte fuel cell. Electrochimica Acta, v. 43, p. 3761-3766, 1998.

93 ZHU, M.; SUN, G.; XIN, Q. Effect of alloying degree in PtSn catalyst on the catalytic behavior for ethanol electro-oxidation. Electrochimica Acta, v. 54, p. 1511-1518, 2009.

94 SU, B.-J.; WANG, K.-W.; CHENG, T.-C.; TSENG, C.-J. Preparation of PtSn/C electrocatalysts with improved activity and durability toward oxygen reduction reaction by alcohol-reduction process. Materials Chemistry and Physics, v. 135, p. 395-400. 2012

95 XU, Z.; ZHANG, H.; ZHONG, H.; LU, Q.; WANG, Y.; SU, D. Effect of particle size on the activity and durability of the $\mathrm{Pt} / \mathrm{C}$ electrocatalyst for proton exchange membrane fuel cells.

Applied Catalysis B: Environmental, v. 111-112, p. 264-270. 2012.

96 LIM, D.-H.; CHOI, D.-H.; LEE, W.-D.; LEE, H.-I. A new synthesis of a highly dispersed and $\mathrm{CO}$ tolerant $\mathrm{PtSn} / \mathrm{C}$ electrocatalyst for low-temperature fuel cell; its electrocatalytic activity and long-term durability. Applied Catalysis B: Environmental, v. 89, p. 484-493, 2009.

97 VOORHEES, P. W. The theory of Ostwald ripening. Journal of Statistical Physics, v. 38, p. 231-252, 1985.

98 GUILMINOT, E.; CORCELLA, A.; CHATENET, M.; MAILLARD, F.; CHARLOT, F.; BERTHOMÉ, G.; IOJOIU, C.; SANCHEZ, J. Y.; ROSSINOT, E.; CLAUDE, E. Membrane and active layer degradation upon PEMFC steady-state operation: I. Platinum dissolution and redistribution within the MEA. Journal of The Electrochemical Society, v. 154, p. B1106B1114, 2007.

99 RODGERS, M. P.; BROOKER, R. P.; MOHAJERI, N.; BONVILLE, L. J.; KUNZ, H. R.; SLATTERY, D. K.; FENTON, J. M. Comparison of proton exchange membranes degradation rates between accelerated and performance tests. Journal of The Electrochemical Society, v. 159, p. F338-F352. 2012.

100 JUNG, J.; PARK, B.; KIM, J. Durability test with fuel starvation using a Pt/CNF catalyst in PEMFC. Nanoscale Research Letters C7 - 34, v. 7, p. 1-8. 2012.

101 LEE, D.; HWANG, S. Effect of loading and distributions of Nafion ionomer in the catalyst layer for PEMFCs. International Journal of Hydrogen Energy, v. 33, p. 2790-2794, 2008.

102 ANTOLINI, E. Formation, microstructural characteristics and stability of carbon supported platinum catalysts for low temperature fuel cells. Journal of Materials Science, v. 38, p. 29953005, 2003.

103 MU, S.; XU, C.; GAO, Y.; TANG, H.; PAN, M. Accelerated durability tests of catalyst layers with various pore volume for catalyst coated membranes applied in PEM fuel cells.

International Journal of Hydrogen Energy, v. 35, p. 2872-2876.2010. 
104 MENCH, M.; KUMBUR, E. C.; VEZIROGLU, T. N. Polymer electrolyte fuel cell degradation. Tennesse: The University of Tennessee Knoxville, 2011. 472p.

105 BORUP, R.; MEYERS, J.; PIVOVAR, B.; KIM, Y. S.; MUKUNDAN, R.; GARLAND, N.; MYERS, D.; WILSON, M.; GARZON, F.; WOOD, D.; ZELENAY, P.; MORE, K.; STROH, K.; ZAWODZINSKI, T.; BONCELLA, J.; MCGRATH, J. E.; INABA, M.; MIYATAKE, K.; HORI, M.; OTA, K.; OGUMI, Z.; MIYATA, S.; NISHIKATA, A.; SIROMA, Z.; UCHIMOTO, Y.; YASUDA, K.; KIMIJIMA, K.-I.; IWASHITA, N. Scientific aspects of polymer electrolyte fuel cell durability and degradation. Chemical Reviews, v. 107, p. 3904-3951, 2007.

106 KINOSHITA, K.; LUNDQUIST, J. T.; STONEHART, P. Potential cycling effects on platinum electrocatalyst surfaces. Journal of Electroanalytical Chemistry and Interfacial Electrochemistry, v. 48, p. 157-166, 1973.

107 MEIER, J. C.; GALEANO, C.; KATSOUNAROS, I.; TOPALOV, A. A.; KOSTKA, A.; SCHÜTH , F.; MAYRHOFER, K. J. J. Degradation mechanisms of Pt/C fuel cell catalysts under simulated start-stop conditions. ACS Catalysis, v. 2, p. 832-843.2012.

108 ARICÒ, A. S.; STASSI, A.; MODICA, E.; ORNELAS, R.; GATTOO, I.; PASSALACQUA, E.; ANTONUCCI, V. Evaluation of high temperature degradation of Pt/C catalysts in PEM fuel cells. ECS Transactions, v. 3, p. 765-774, 2006.

109 KNIGHTS, S. D.; COLBOW, K. M.; ST-PIERRE, J.; WILKINSON, D. P. Aging mechanisms and lifetime of PEFC and DMFC. Journal of Power Sources, v. 127, p. 127-134, 2004.

110 SHI, M. H.; WANG, J.; CHEN, Y. P. Study on water transport in PEM of a direct methanol fuel cell. Journal of Power Sources, v. 166, p. 303-309, 2007.

111 SAYIN, E. S.; BAYRAKCEKEN, A.; EROGLU, Ä. N. Durability of PEM fuel cell electrocatalysts prepared by microwave irradiation technique. International Journal of Hydrogen Energy, v. 37, p. 16663-16672. 2012. 